\title{
6 Editions
}

Introductory remarks by the chapter editor, Aidan Conti

Most readers and scholars encounter stemmatological practices when using an edition. While the detailed questions taken up in dedicated stemmatological studies and examinations occupy specialists, practically speaking stemmatology is employed in the service of producing a critical edition. The edition, however, is not a single, monolithic entity but a product that can be representative of a number of academic traditions and scholarly practices. Indeed, many editions are produced without using the stemmatological method. Consequently, it is not surprising that there is no shortage of books and essays that endeavour to set down how a text should be edited and what tools should be used. Recent handbooks espousing the genealogical tradition include Richard Tarrant's Texts, Editors, and Readers (2016) and Paolo Trovato's Everything You Always Wanted to Know about Lachmann's Method (2017). Ralph Hanna's Editing Medieval Texts (2015), on the other hand, espouses the principle of selecting a single manuscript while comparing known witnesses for variants (see Göransson 2018 for an account). While individual experience and academic orientation will necessarily shape and be apparent in individual contributions within this chapter, overall the chapter ventures to provide a practical survey of types of editions and editing tools, with a specific emphasis on the process of establishing a critical text through the common-errors method.

Given the variety of methods used to produce an edition, this chapter begins with Odd Einar Haugen's systematic description of various editorial practices (6.1), those that have tentatively employed stemmatology and those that have different theoretical bases for the presentation of edited text. Haugen usefully distinguishes reconstructive editing, which aims to present a hypothetical original or archetypal text, and non-reconstructive editing, which uses an extant witness as the basis for an edition. In the case of most editions, we see a link between the methodology used to establish the edited text and the presentation of the edited text. However, as Haugen shows, in some cases an editor may provide and argue for a stemma, but not use the stemma to present a reconstructed text.

In the subsequent section (6.2), Marina Buzzoni addresses the specific case in which the stemma is used to produce a critical text with the genealogical or common-errors method. The principles of the method and criticisms of it have been presented in earlier sections (see e.g. 2.2, 2.3). Buzzoni offers a number of examples from textual traditions that illustrate the principles of recensio (the establishment of the stemma and the classification of witnesses and readings), emendatio (the selection and emendation of readings), and dispositio (the final stage of laying out the edited text, apparatuses, and other material). The section also examines new perspectives that arise out of an increasing awareness of the prevalence of traditions that resist the clear lines and structures of a closed tradition, such as Wulfstan's 
Sermo Lupi ad Anglos, Boiardo's Amorum libri, and La Vie de Saint Alexis, which will be familiar to readers of section 2.3.

Franz Fischer then (6.3) examines the presentation of the critical text. Of particular interest are the standards and conventions that have developed for print over the past two centuries and the ways in which the digital paradigm suggests changes and challenges to these conventions. Indeed, while new tools challenge conventions, the digital environment has implications and ramifications for the very idea of the edited text as well. As part of this survey, Fischer examines the question of what information should be included, and the capabilities and limitations of various formats. Of particular interest is the critical apparatus, which provides the evidence which supports and allows the reader to test the hypothesis of the edited text.

In the final section of this chapter (6.4), Tara Andrews continues the discussion of the digital paradigm, but shifts the focus to digital tools in the humanities and the current environment, that is support, or lack thereof, for them. This section surveys different forms of digital publication, from digital editions that require publication in print to those that are developed for online use. As Andrews indicates, despite the challenges facing those navigating digital publication - from the complexities of XML to the lack of infrastructure maintenance - the policies of funding bodies that mandate digital publication of supported editorial projects represent promising initiatives to ensure the availability of scholarly texts. Indeed, as availability becomes more widespread - at least for those with access to the Web - questions concerning increased public engagement and social relevance promise to represent critical concerns for all those engaged in producing and studying scholarly editing.

This chapter is structured so that the sections move from general considerations regarding types of critical editions to the specifics of developing a critical text using the common-errors method, from theoretical considerations regarding the presentation of a contemporary edition to the specific tools that can be used for digital publication. Some readers may find it more beneficial to read sections in a different order; in particular, the reader might find the material more approachable by reading about the specific tools that can be employed to develop a digital edition (6.4) before exploring the more theoretical concerns relevant to publication (6.3).

As this chapter addresses the forms and production of the scholarly edition, it becomes increasingly clear in the course of reading that the question of engaging users in the textual resources that scholars have developed is equally important. It is hoped that the examples and studies provided in this chapter present those curious about the development of scholarly editions with a more approachable vision of the field. 


\title{
6.1 Types of editions
}

\author{
Odd Einar Haugen
}

The great majority of stemmata are to be found in introductions to editions, offering a graphical view of the interrelationship of the manuscripts and opening the door, as it were, to the edited text. In many editions, therefore, the stemma is actively used in the establishment of the text, the constitutio textus, as performed by the editor and shown in the apparatus to the text. However, many editions do not offer a stemma at all, and there are also examples of stemmatic analyses which are made outside any edition. After presenting a simple model of editions, this section will look at reconstructive and non-reconstructive editing, and the particular challenges posed by textual uniformity in reconstructive editions. A final discussion will address editions which, paradoxically, open with a full stemmatic recensio but do not implement it in the actual editing. In keeping with the author's background, the majority of examples will be taken from mediaeval vernacular philology.

\subsubsection{Types of editions}

For many textual critics, an edition is the end product of their editorial project. After going meticulously through the witnesses to the work, the editor has the opportunity of presenting the result in an edition which, in some cases, is refreshingly simple or, in other cases, a highly complex enterprise with multiple apparatuses and a host of editorial signs sprinkled over the pages. In the present introduction to stemmatology, the focus will be on editions that lay down and use a stemma for the actual establishment of the text, the constitutio textus, as explained in section 6.2.1 below. There are, however, many other types of editions, so a general overview will be helpful to put the complex, stemma-based editions in perspective. The very first question concerns the number of witnesses to the work that is going to be edited. This number can by anything from one, in the case of a codex unicus, to around five thousand (the Greek New Testament).

Assuming that there is more than one witness to the work, editors will, as a rule, try to base their editions on the whole tradition. In some cases, however, the editor may decide to look away from the broader transmission and follow a single manuscript, and only this manuscript, in what may be called a monotypic or monoptic edition (see Haugen 2013, 40; 2.1 .3 above). If there is a generally accepted edition of the work based on the whole textual transmission, a monotypic edition may be seen as a supplementary type of edition, allowing users to focus on the orthography, style, or organisation of a single witness.

While the editors of some monotypic editions choose a close and faithful rendering of the source, often referred to as a diplomatic rendition, other editors prefer to regularise the orthography partially or completely. An example of both 
approaches is offered by the Old Norwegian translation of the Anglo-Norman lais of Marie de France, known as the Strengleikar, preserved in a single, partly fragmented manuscript, Uppsala, Universitetsbiblioteket, DG 4-7 fol, from ca. 1270. The Strengleikar can be studied in the diplomatic edition and translation into English by Mattias Tveitane and Robert Cook (1979), and in a fully regularised orthography by Aðalheiður Guðmundsdóttir (2006) - regularised, in fact, into modern Icelandic.

For the editor who would like to base an edition on more than one witness, there are basically two options available. One is to continue, as it were, the monotypic style, but offering two or more manuscripts at the same time. This is the synoptic edition, of which there are two major types. One is the juxtaposition of different versions, even in different languages, of essentially the same work, such as the famous Hexapla compiled by Origen of Alexandria in the third century AD. In this edition, preserved only in fragments, no fewer than six versions of the Old Testament are compared in parallel columns - two in Hebrew and four in Greek. Another example of this type is the display of closely related works, such as the 1776 synoptic edition of the Gospels of Matthew, Mark, and Luke by Johann Jakob Griesbach (see Greeven 1978). The other type is the juxtaposition of witnesses to the same work, thus, in principle the basis for a critical recensio. The four manuscripts displayed side by side in Jean Rychner's edition of Lanval (1958) in figure 6.1-6 below are one example; the two versions of Porláks saga helga in the split-level edition by Jón Helgason (1978) in figure 6.1-7 are another. It should be noted, however, that the two types of synoptic editions may overlap, depending on the delimitation of the work and its witnesses.

As long as the synoptic editions of either type are confined to print, there is an upper limit to how many versions of the text can be displayed simultaneously. More than, say, six will not be practicable, unless the text is very short. In print, synoptic editions will organise the text in either vertical columns or horizontal blocks. As long as the texts to be compared synoptically are fairly close in form and content, the actual layout is not a huge challenge, apart from the fact that there may be a lot of white space if one text is considerably shorter than other texts. More challenging are transpositions in the text, which is why the Gospel of John, a Gospel differently organised compared to the other three, was not included in the earliest synoptic editions (it was included for the first time in the 1797 edition by Griesbach; see Greeven 1978).

The eclectic edition will, as a rule, be based on more than one witness and never rely exclusively on any one of them. The term "eclectic" has pejorative connotations for many scholars, implying a lack of rules or principles, but within editorial theory, it is generally used in a neutral sense, for example in the editing of the Bible (7.6.3), in the editing of mediaeval German texts (7.4.5), or in the editing of Anglo-American authors (see e.g. Bowers 1975b; Tanselle 1994). This neutrality also applies to the typology advocated here. Eclectic editing goes a long way back the celebrated edition of the Greek New Testament by Erasmus of Rotterdam in 1516 
is a type of eclectic editing, understandably so, given the overwhelming number of manuscripts and the practical difficulties in accessing them (see 2.1.3). Many eclectic editions were also made after the methodological advances of the nineteenth century, as exemplified by the edition of Barlaams ok Josaphats saga by Rudolf Keyser and Carl Richard Unger (1851), discussed in section 6.1.2.

Among the eclectic editions, the principal group (from the perspective of this book) is the strictly critical edition, which is an edition based on a genealogical recensio of the manuscripts and using this information in the establishment of the text. This has been, and remains, the preferred type of edition within classical scholarship, and it is the premier type of edition for any stemmatological recensio. As Richard Tarrant points out, almost any critical edition in the classical field has an eclectic basis (2016, 125), but he also underlines the importance of conjecture when dealing with textual difficulties - the emendatio ope ingenii has a long, though contested, tradition in textual scholarship (see 2.1, 6.2). Critical editions of the type favoured in classical scholarship are also found in other fields of editing, but possibly to a lesser extent due to the nature and distribution of the manuscript material. As argued in section 6.3.1, there are many editions which can be described as critical in the sense that they offer structured information on a number of aspects of the text, even if the actual establishment of the text is not as would be expected in a truly critical edition. The same applies to editions in the field of Old Norse, such as in the leading Editiones Arnamagnæanæ series, where the genealogical recensio is dutifully carried out in the introductions but the edited texts are established not on this basis, but more often than not in what might be called a critical synoptic edition, exemplified in figure 6.1-7 below. On this seemingly contradictory procedure of editing, see the historical and methodological overview by Louis-Jensen and Haugen (in press).

If the eclectic editions in figure 6.1-1 are thought of as occupying concentric circles, the strictly critical editions will populate the inner circle while the basically pre-Lachmannian editions will orbit in the outer circle. In between, there will be editions which are not strictly critical but which contain a methodological approach to the text which far exceeds that of the editions in the outer group. As in all typologies, there will be editions which can be placed in more than one group, and there are also examples of critical editions to the left of the dividing line in figure 6.1-1. A number of important texts have only been preserved in a single manuscript, such as, in Old High German, the short poem Muspilli in München, Bayerische Staatsbibliothek, Clm 14098 (ninth century) and the equally short Hildebrandslied in Kassel, Universitätsbibliothek, $2^{\circ}$ Ms. theol. 54 (ninth century), or, in Old English, the extensive Beowulf in London, British Library, Cotton Vitellius A.xv (early eleventh century). These works may offer fertile ground for e m e n d a t i o n s to the text, an operation which is regarded as part and parcel of critical editing (see 6.2.3, esp. 6.2.3.1). As has been concisely put forward by Franz H. Bäuml:

The editor of a unique manuscript has two possible courses of procedure open to him, depending on whether he is concerned with establishing the Urtext of his manuscript per se. If it is 


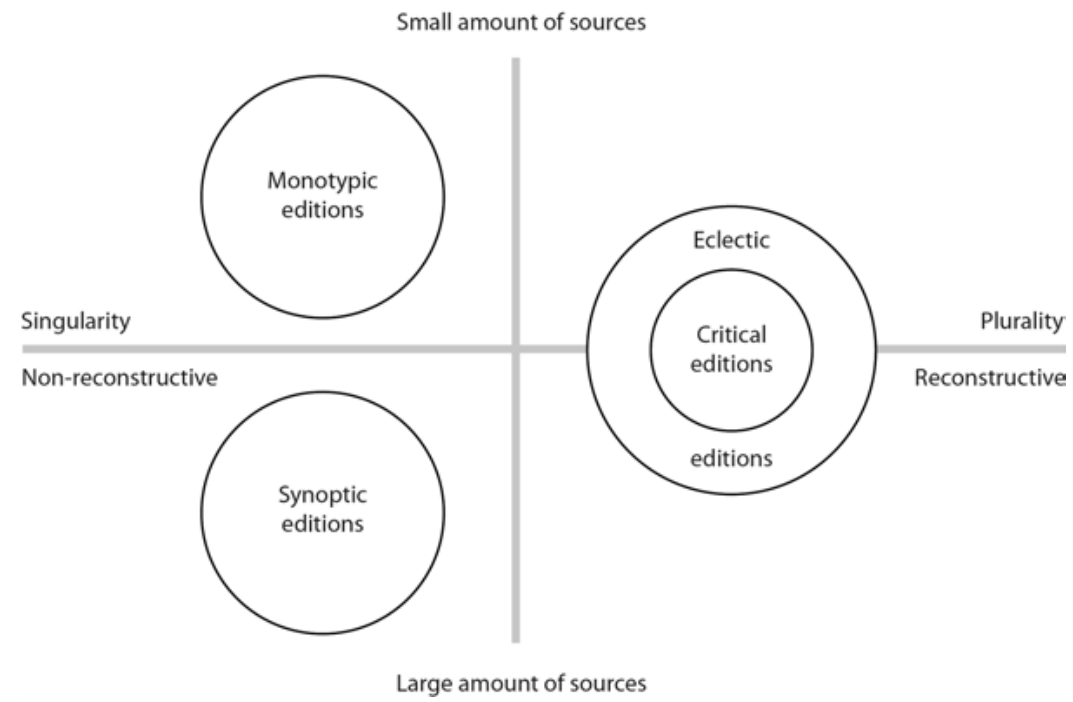

Fig. 6.1-1: A dichotomous view of editions (details in the main text). For another basically dichotomous model, see Göransson (2016, 421, fig. 2). The latter model charts the continuum between what the author calls "diplomatic" and "revisionist" approaches, a continuum which is comparable to the horizontal axis in the present model.

his intention to establish the Urtext, he can avail himself of only one aspect of textual criticism, and that in isolation: since the techniques of heuristic, collatio, recensio are not applicable, he is limited to the emendatio. However, lexical emendation of all three types - with full, with partial, and with no palaeographical justification - is for the most part a comparative method and therefore also largely inapplicable, except in such cases where internal comparisons within a given text or type of text are possible. Where this is not the case, his emendations will be formed according to the principles of Konjekturalkritik. (Bäuml 1961, 27)

Since many early and, by that token, important works have been preserved in single and often fragmented manuscripts, much editorial zeal has been applied to them. An apt example is offered by the Old Norse Eddic poems; the majority of these have been handed down to us in a single manuscript, Reykjavík, Safn Árna Magnússonar, GKS 2365 4to (ca. 1270). Due to their literary and mythological value, the number of $E d d a$ editions is high and the secondary literature large. The Kommentar zu den Liedern der Edda in seven volumes (von See et al. 1997-2019) contains a full rendering of the Eddic poems, accompanied by a vast line-by-line commentary. The size of this commentary is in fact comparable to the apparatus that can be found in many critical editions.

In the simple and dichotomous view of editions discussed here, as displayed in figure 6.1-1, monotypic and synoptic editions are located to the left of the dividing line, distinguished by their singularity in the rendition of the sources, while the eclectic editions (and, within this group, the critical editions) are located to the right 
of the dividing line. While, from a stemmatological point of view, the editor of a monotypic edition may be envied for the ease of the undertaking, and the editor of a synoptic edition criticised for not standing up for a preferred version of the text, the editor of a critical edition has nowhere to hide. From the perspective of Karl Popper (1965), the critical edition delivers the most audacious hypothesis on the text and as such is continuously in danger of being refuted, but for this very reason it has the strongest explanatory power.

The critical edition is usually defined by virtue of its recensio and the implementation of its results in the text, in particular the selection of readings when the manuscript evidence is in conflict. This is, however, not the only challenge for the critical editor, especially not for editors of vernacular texts. In the introduction to the edition of the Old French Alexis legend, Gaston Paris draws a distinction between two major steps in the making of an edition, first the constitution of the readings (constitution des leçons) and second the constitution of the language (constitution du langage; Paris and Pannier 1872, 14). The first step is common to most texts discussed in this volume and is also examined in section 2.3.2 above. Referring to the simple model in figure 6.1-1, this step will be discussed below as a choice between reconstructive and non-reconstructive editing, or, as many would put it, between critical and non-critic al editing. The second step is less acute for the editing of classical texts, where there is a long-standing tradition of regularising the orthography of the manuscripts and often scant interest among editors in this seemingly accidental variation. For vernacular texts, which have often been preserved in manuscripts of highly variable orthography, this is a question that the editor simply cannot avoid. It is perhaps not surprising that the greater part of the introduction to the Alexis legend is devoted to la constitution du langage. Below, this will be discussed under the heading of "textual unity" (6.1.5).

Ultimately, the choice of edition depends on the manuscript material. In the case of a codex unicus, there is little choice other than a monotypic edition. However, if the manuscripts contain a translation for which the source text has been identified, it is still possible to bring in an outside view of the text. A case in point is the above-mentioned Strengleikar manuscript (ca. 1270), which contains a rather free translation into Old Norwegian prose of the octosyllabic lais by Marie de France. Manuscript $H$, London, British Library, Harley 978 (thirteenth century), appears to be the closest to the translator's unknown exemplar. Even if the Strengleikar translation differs in many respects from its source, there are many readings which can be better understood after a comparison with the source, so that problematic readings can be emended with a high degree of certainty (for examples, see Budal 2009). There will also be cases where other versions of the manuscript text may shed light on its conceptions and readings, even if these versions cannot be used in a strict genealogical recensio.

When a work has been preserved in more than one manuscript, which probably is the case in the majority of instances, the type of edition to be chosen is still 
an open question. There are many considerations: the size and complexity of the manuscript material, the degree of horizontal transmission (or contamination), the degree of fragmentation, the existence of previous editions and their various strengths (or, indeed, weaknesses), and so on. In some cases, it will be possible to work towards an archetype, as in reconstructive editions. In other cases, it may be futile to do so, so the editor is left with the choice between a non-reconstructive edition, be it of a single, best, or most typical manuscript, and a selection of manuscripts in a synoptic approach.

Finally, it should be mentioned that a distinction may be drawn between, on the one hand, popular editions, intended for use in schools or for the general public, and, on the other hand, scholarly editions. The former type of edition is usually based on established scholarly editions, simplifying their often complicated interfaces and sometimes regularising the orthography. It goes without saying that it is the latter type which is discussed here, but that is not to say that popular editions should be disregarded. Many editors have offered both types of editions themselves, such as the two Old French editions by Jean Rychner discussed at the end of section 6.1.3.

There are numerous introductions to the art and science of editing texts, and several offer typologies. In spite of its modest title, "Some Types of Scholarly Edition”, appendix 2 in Greetham (1994) is a good starting point, while later attempts can be found on a grand scale in Sahle (2013) and more briefly in Haugen (2014); see also 6.3 below.

\subsubsection{Reconstructive editions}

The editing of handwritten texts from the classical and mediaeval era has often taken the form of a reconstructive enterprise in which the editor tries to trace the text back to its original, removing errors and innovations in the manuscript transmission as he or she slowly sifts through the preserved material. It is commonly assumed that the original of all classical texts has been irrevocably lost:

Eigenhändige Niederschriften (Autographa) der griechischen und lateinischen Klassiker besitzen wir nicht, auch keine Abschriften, die mit dem Original verglichen sind, sondern nur solche Abschriften, die durch Vermittlung einer unbekannten Zahl von Zwischenhandschriften aus dem Original abgeleitet, also von fragwürdiger Zuverlässigkeit sind. (Maas 1960, 5)

[We have no autograph manuscripts of the Greek and Roman classical writers and no copies which have been collated with the originals; the manuscripts we possess derive from the originals through an unknown number of intermediate copies, and are consequentially of questionable trustworthiness.] (trans. Flower 1958, 1)

Also for mediaeval texts, preserved originals are indeed rare. Furthermore, for classical as well as mediaeval texts, the ensuing copies have also been lost to a very high extent. It is impossible to give an exact estimate of this loss of manuscripts, 


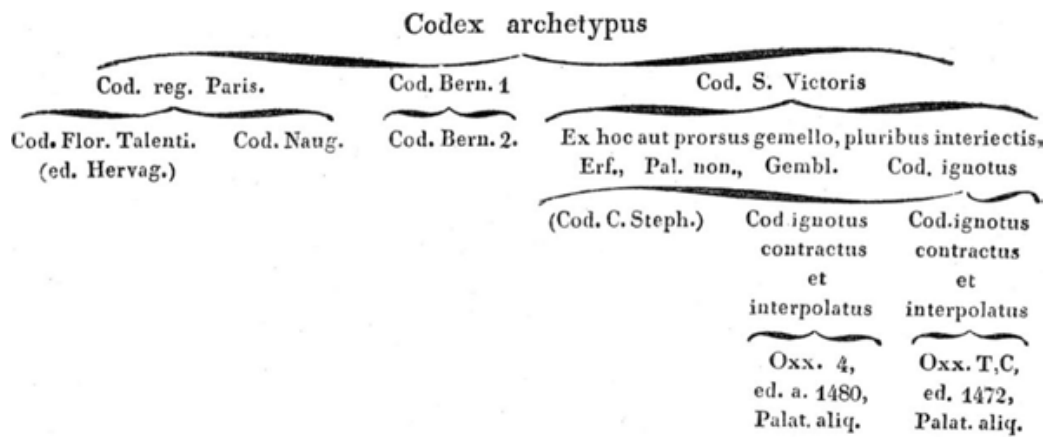

Fig. 6.1-2: The stemma for the manuscripts of two speeches by Cicero in Madvig (1833-1834, 1:9). Note the term "Codex archetypus", which probably should be taken to mean "original". In the treatise of Paul Maas (1st ed. 1927, 4th ed. 1960), "archetype" received a more technical meaning, as explained in section 4.1 above.

and it probably varied across genres and periods, but it is not uncommon to estimate that around $90 \%$ of mediaeval manuscripts have been lost (Guidi and Trovato 2004; Åström 2005, 1071). As a consequence of this loss, an edited text can be no more than an approximation of the once-existing original. However, the edited text can claim to be the optimal text, insofar as the point of the editorial exercise is to trace the history of the text as far back as possible. This program is what Karl Lachmann (1793-1851) succinctly formulated in 1817: "Wir sollen und wollen aus einer hinreichenden Menge von guten Handschriften einen allen diesen zum Grunde liegenden Text darstellen, der entweder der ursprüngliche selbst seyn, oder ihm doch sehr nahe kommen muss" (Lachmann 1876, 1:82) [On the basis of a sufficient number of good manuscripts, we should and want to build a text which reflects all of these, a text which either will be the original text or must come very close to it].

The approximation of the original was later termed the "archetype" (e.g. in Maas 1960, 6). Since the generation of Karl Lachmann (although not by Lachmann himself), the process of copying a text has been modelled as a tree turned upside down, a stemma codicum (see 4.1). The stemma has the original on top, the archetype directly beneath it, and the preserved manuscripts as leaves on the branches below. Stemmata can be drawn in different ways, but they are all basically tree models, depicting the copying process through one or more (usually many) generations of manuscripts.

The earliest full-scale stemma is found in the edition of the Westrogothic law, Västgötalagen, by the Swedish scholars Carl J. Schlyter and Hans S. Collin (1827), reproduced in figure 4.1-1 above. According to Britta Olrik Frederiksen (2009, 139148), of the two editors, Schlyter should be regarded as the author of the stemma. Probably due to the fact that the Västgötalagen is a vernacular text, it remained isolated (see G. Holm 1972), also, perhaps, because of the modest location of the stemma on a small fold-out slip in an appendix to the edition. It is correct, as Sebastiano Timpanaro pointed out when he was made aware of this stemma, that it is 
not part of a genealogical recensio (Timpanaro 2004, 61-62; trans. Most 2005, 92), but it certainly comes across as a surprisingly modern tree.

A few years later, the Danish classical scholar Johan Nicolai Madvig published a stemma for the manuscripts of Cicero's Oratio pro Publio Sestio and Oratio in Vatinium, reproduced in figure 6.1-2 here. This was not part of a recensio for an edition, but since it was published by a leading classical scholar it had a much greater impact than Schlyter's stemma. When the stemma gradually made its way into editorial practice in Nordic philology, it was most likely through Madvig's teaching and example rather than the contribution by Schlyter. Like his colleague in Berlin, August Boeckh, Madvig was active in teaching for around five decades, and, like Boeckh, he frequently gave a course on the "Encyclopedia of Philology". Madvig was appointed professor in 1829 and kept teaching until he retired in 1880. In this long period, he influenced two generations of editors, of classical as well as of vernacular texts (see Ræder and Larsen 1981).

In the mid-nineteenth century, editions of texts in the vernaculars were on the whole eclectic, not only among Nordic scholars but also among other European editors. These editions were not critical in the strict sense defined above, since they did not offer a genealogical recensio of the manuscripts, nor did they build a text on the basis of a recensio. This does not mean that vernacular editing of the time should be discarded as unscholarly, only that editing in this field had not yet been informed by the later developments in the genealogical method. One example is the editing of the Latin Barlaam legend. When Rudolf Keyser and Carl Richard Unger edited the Old Norwegian translation of this legend, Barlaams saga ok Josaphats (1851), they were faced with a highly fra g m e n ted corpus of textual witnesses. Of the around fifteen preserved witnesses, many of which were small fragments, not a single one contained the entire text, and many manuscripts were much younger Icelandic specimens in a distinctively later orthography. Fortunately, one of the earliest manuscripts was fairly complete, preserving around $95 \%$ of the text. This was an eastern Norwegian codex, Stockholm, Kungliga biblioteket, Holm perg 6 fol (ca. 1275), and it is the uncontested codex optimus of the saga. In their polished eclectic edition, Keyser and Unger followed this manuscript as far as possible, and supplied missing text from younger Icelandic manuscripts whenever necessary. Since the orthography of the main and the supplementary manuscripts was strikingly different, they decided to regularise the orthography of the younger manuscripts according to the thirteenth-century Norwegian orthography of the main manuscript. This meant that they, in a sense, back-dated the younger manuscripts more than two centuries. The result was a uniform edition, kept in a single, old Norwegian orthography throughout. It was an edition of the work, not of its witnesses. It is still regarded as an eminent edition, and it remains the only edition offering a complete and unbroken rendition of the work.

Possibly the first stemmata which appeared as part of a truly genealogical recensio were published in the above-mentioned edition of the Alexis legend by Gas- 


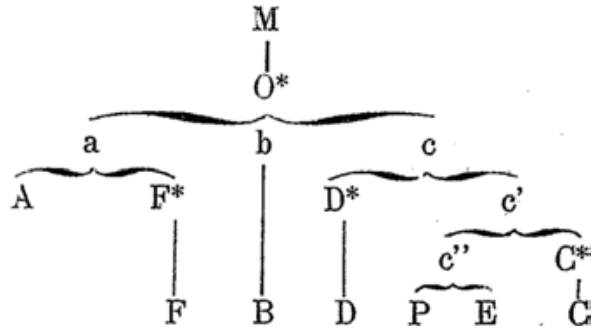

Fig. 6.1-3: The stemma for the latest, fourteenth-century version of the Alexis legend, drawn by Léopold Pannier.

Source: Paris and Pannier (1872, 344).

ton Paris and Léopold Pannier (1872). The stemma for the manuscripts of the earliest, eleventh-century version of the legend was drawn by Paris and is reproduced in figure 7.3-1 below. Pannier drew the second stemma, for the latest, fourteenthcentury version of the legend, reproduced here in figure 6.1-3. This is remarkable as an example of a tripartite stemma, which (as explained by Pannier) can be used to determine readings one by one:

Voici maintenant comment je procède pour l'établissement du texte. Ayant d'abord la version de $a$ (A confirmé par F), je considère si elle concorde avec $b$ (B) et $c$ (C D P E). Quand les trois groupes sont conformes, la leçon est assurée. Quand deux seulement le sont, ils condamnent le troisième. Mais lorsque les trois leçons diffèrent, j'examine, d'après le sens, la valeur de chacune d'elle. Si aucune ne s'impose, je préfère les manuscrits dans l'ordre suivant: A, puis B, puis D, qui est un bon manuscrit. (Paris and Pannier 1872, 344-345)

[This is how I proceed for establishing the text. After having secured version $a$ ( $A$ confirmed by $F)$, I assess whether it agrees with $b(B)$ and $c(C D P E)$. When the three groups agree, their readings are confirmed. If only two groups agree, they exclude the third. If readings in three differ, I examine the value of each reading according to its sense. If no reading is stronger, I select the manuscripts in the following order: $A$, then $B$, then $D$, which is a good manuscript.]

The procedure described by Pannier turned a tripartite stemma into an automaton, since it could be used to select readings by a simple majority rule among the hyparchetypes, in this case $a, b$, and $c$, thus denying the editors the right to select for themselves. In fact, the majority rule will apply to any stemma with three or more hyparchetypes, as long as there is a majority among readings. Joseph Bédier's later criticism of the unyielding force of the tripartite stemma is discussed in section 2.3.4 above.

From the 1870s, a growing number of editions were based on a genealogical recensio of the manuscripts and embellished by one or more stemmata. This type of edition was applied to a great many literatures, classical as well as vernacular. In Old Norse editing, the earliest example of a genealogical recensio with a full stemma codicum is to be found in the edition of Fljotsdǿla saga. This is a late mediaeval Icelandic saga which was edited by the Danish scholar Kristan Kålund (1883); the stemma is reproduced in figure 6.1-4.

Kålund argues explicitly on the basis of the distribution of "fælles fejl" [c o m mon errors] in the manuscripts, and claims that there are some errors in all the preserved manuscripts; in other words, there must have been a less faulty, but nowlost, manuscript $X$ from which the preserved manuscripts are derived. Kålund con- 


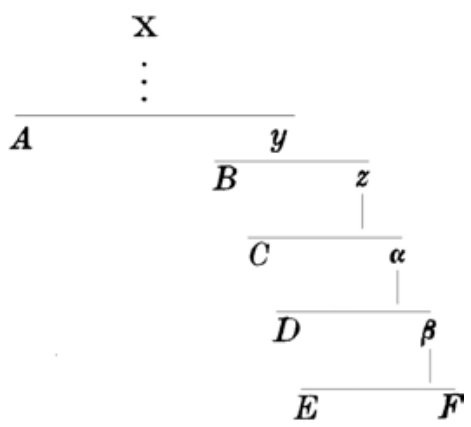

Fig. 6.1-4: The stemma for the six manuscripts $A-F$ of Fljótsdǿla saga by Kristian Kålund (1883, xvii). It is striking that this stemma has a high number of repeated bifurcations, a trait that Timpanaro, among others, found problematic (see the posthumous appendix, "Final Remarks on Bipartite Stemmas", in Timpanaro 2005, 214).

tinued his work with the more prominent Laxdǿla saga, which he edited and published in two volumes (1889-1891). Worth mentioning is also the complex and highly reconstructive edition of Piðriks saga af Bern (i.e. Verona) by another Dane, Henrik Bertelsen, published in two volumes (1905-1911). These editions offer a recensio of the manuscripts, a stemma, and a text which has been informed by the genealogical recensio.

When Jón Helgason, who later founded the definitive Editiones Arnamagnæanæ series (in 1958), edited a selection of Old Icelandic bishops' sagas, it was in a truly critical edition (1938). He explained his selection of readings, the constitution des leçons in the terms of Gaston Paris, with reference to the stemma he had arrived at, and he decided to render the text in regularised orthography. Figure 6.1-5 shows a typical page from this edition, in which the apparatus is divided into two levels: the upper level contains variation that is relevant for the establishment of the text, which might be called substantial variation, and the lower level covers accidental variation, which does not interfere with the establishment of the text. This is an edition of a vernacular text with a high degree of linguistic variability, but it was done in accordance with practice in classical editing and thus suppressing the linguistic variation in favour of reconstructing the work in its presumed original orthography of the early thirteenth century.

Among editors of classical texts, the genealogical method still holds sway. The stemma is the uncontested model, and the construction of the text is informed by recensio. However, it is a type of edition which seems best suited to prominent works, that is, works that have been preserved with a high degree of faithfulness to the chain of exemplars and a low degree of interference from other branches of the tradition - or simply, as Karl Stackmann concludes, it is preferable for classical texts that are seen as authoritative (1979, 252). For other types of editions and editorial traditions in various language areas, see the overviews in chapter 7 below, and also the typology in section 6.3 . 
59 1. Bœkling penna kalla ek Hungrvǫku, af pví at svá mun mǫrgum mǫnnum ófróðum, ok pó [eigi] óvitrum, gefit vera, peim er hann hafa yfir farit, at miklu* mundu gørr vilja vita upprás ok ævi 3 peira merkismanna er hér verơr fátt frá sagt á pessi skrá. En ek hefi pó nálega ọllu við̌ slegit, at rita pat sem ek hefi í minni fest. Hefi ek af pví penna bœkling saman settan, at eigi falli mér með 6 ǫllu ór minni pat er ek heyrớa af pessu máli segja hinn fróða mann Gizur Hallsson, ok enn nǫkkura menn aðra merkilega hafa í frásọgn fœrt. Pat berr ok annat til pessa rits, at teygja til pess unga 9 menn, at kynnisk várt mál at ráōa, pat er á norrœnu er ritat, lọg eð̃a sǫgur eð̃a mannfrœð̌i. Set ek af pví heldr petta á skrá en annan fróðleik pann er áor er á skrá settr, at mér sýnisk mínum bǫrnum 12

Overskrift: Hungurvaka $B^{1}$, Hier Byriar Hungur wóku $B^{2}$, Eirn lytell Bæklingur af făum Byskupum sem verid hafa ă Islande peim fyrstu og huornenn Skalhollt var fyrst Bygtt og par settur Byskups stöll og af huórium pad var tilsett og nær (og nær] $\div C^{2}$ ) $C^{1 \cdot 2}$, Bæklïngur af nockrum Biskupum peim firstu sem vered hafa ä İslande: og hvorninn Skälhollt var first biggt og af hvurium og hvenær pad var tilsett $C^{3}$. Herefter ny overskrift til kapitlet: Formälenn $C^{1 \cdot 2}$, Formäle [incerti authoris] $C^{3}$. 2 eigi] $\div B C(\mathrm{og}$ udgg.), indsat (ved konjektur) $i$ afskriften $1 B 62$ fol; enkelte hskrr. (AM 373 , 4to m. m.) boder paa fejlen ved at æendre óvitrum til vitrum (saal. ogsaa OrIsl). 3 miklu] + meir $B$. 4 verôr fátt] verid haffa og fatt verdur , C. á] j $B^{2} C^{1} .5$ pó] $\div C .8$ nọkkura] marga $C^{1 \cdot 3} .9$-sọgn (saal. $B^{1}, A M$ leser $i A M 376$, Ato med urette -saugu)] sógu $C^{1 \cdot 2}$, -sógur $B^{2} C^{3}$. berr] bar C. $10 B^{2}$ interpungerer: mál, at ráoa pat er (saal. Bps, Kahle), $B^{1}$ har intet skilletegn her. Af C-haandskrifterne, som har pá (= pá er) for pat er (jfr. flg.), har $C^{1}$ ingen interpunktion her, $C^{3}$ komma efter ráða og ritat, $C^{2}$ komma efter ritat (det fjernes $i$ afskriften AM211 fol, hoor teksten saal. lyder: mäl, ad rada pa a Norænu er ritad lóg osv.). pat er] pa $C$. 11 af] a $C$. á] ad $C$ (idet skrá opfattes som infiniliv). 12 er(2)] oprdl. er eigi? á - settr] skräsettur $C^{1}$. skrál skrar $C^{2 \cdot 3}$ (og OrIsl).

For kap. 1 har $D$ : I fyrstu vil eg nu segia fra pvi hversu bærinn hefur bygdzt j Skalhollti, og sidan fra peim er hann hafa halldit. 2 vera] verda $C^{2}$. 3 vilja] efter vita $C^{2.3}$. 5 fest] sett $C^{2}$. $\quad 6$ eigi] ecke $C^{3}$. 7 fróøa] froma $C^{2}$. 10 kynnisk] kynnast $B^{2}$. 11 pvi] pa $C^{3}$.

Fig. 6.1-5: The Old Icelandic Hungrvaka in the edition by Jón Helgason $(1938,72)$.

\subsubsection{Non-reconstructive editions}

If there is just a single witness to a work, the editor is forced to rely on it, and there can be no reconstruction based on the evidence of lost manuscripts. At best, the editor can argue on the basis of presumably better readings and e m en the text, as Franz H. Bäuml pointed out in the quotation above (6.1.1). However, in the case of works preserved in more than one manuscript, an editor may also decide to focus on just one of the manuscripts, typically the one regarded as the best. While nobody would argue against selecting a supposedly best manuscript for a non-reconstructive edition, there are also manuscripts which are not regarded as the best but are still considered worthy of an edition for other reasons.

One example of a non-reconstructive edition is offered by the Old Norwegian Barlaams saga ok Josaphats (mid-thirteenth century). The eclectic edition by Keyser 
and Unger (1851), referred to above, was supplemented by a new, monotypic edition by Magnus Rindal (1981), based on the main manuscript, Stockholm, Kungliga biblioteket, Holm perg 6 fol. This manuscript is presented "as is", with all lacunae and errors. Since the first leaves of the manuscript have been lost, it opens in medias res with "oc mællte ekki fleiri orðum" [and did not utter any more words]. The text is rendered in a diplomatic manner, so that it is a faithful linguistic source, and this was indeed the main motivation for the edition. The work as such has not been highly regarded, at least not by earlier scholars, but it is beyond doubt an important source for the eastern Norwegian language of the thirteenth century. From this perspective, it is the document Holm perg 6 fol (covering approximately $95 \%$ of the entire text) which is of scholarly interest. Supplying passages from later manuscripts for the remaining $5 \%$ would simply be regarded as noise, distorting the linguistic data. Barlaams saga ok Josaphats in Holm perg 6 fol has since been published with full morphological annotation in the Medieval Nordic Text Archive (menota.org), which is a reminder that editions of some text traditions may be more suited to digital channels than other types (see 6.3 below).

Another example is the famous Prose Edda by the Icelander Snorri Sturluson (d. 1241), which illustrates and explains Old Norse mythology. This work has been preserved in four major manuscripts with varying degrees of fragmentation. København, Det Kongelige Bibliotek, GKS 2367 4to, dated to ca. 1325, is regarded as the codex optimus among them, and it has been edited and translated a number of times, recently in an edition with regularised orthography by Anthony Faulkes (1982) and in a translation into English also by Faulkes (1995). Another of the four manuscripts, Uppsala, Universitetsbiblioteket, DG 11 4to, has a somewhat earlier date, ca. 13001325, but it is regarded as a kind of bête noir, having a rather different and sometimes convoluted style. The relationship between the major manuscripts of the Edda has not been fully explained; for this reason, and because of the intrinsic qualities of the Uppsala Edda, this manuscript has been edited (and translated) on its own by Anthony Faulkes and Heimir Pálsson (2012).

In the case of an open and perhaps inconsistent textual tradition, monotypic editions may seem the best route to follow. As long as the number of presumably good manuscripts is not too high, this is also a recommendable archive solution, in the sense that several monotypic editions of the same work offer a fuller view of the textual variation than an apparatus can. As such, monotypic editions can prove to be the first step towards a reconstructive edition, an edition that metaphorically hovers above the individual monotypic editions, drawing its readings from them.

There are examples of editions which combine the two opposing perspectives in figure 6.1-1, mediating between a non-reconstructive and reconstructive approach, as it were. The experimental edition of the Old French Lanval by Jean Rychner (1958), depicted in figure 6.1-6, is worth mentioning. Here, the text is synoptically presented, on facing pages, from the four manuscripts, $P, H, S, C$, each in its own 

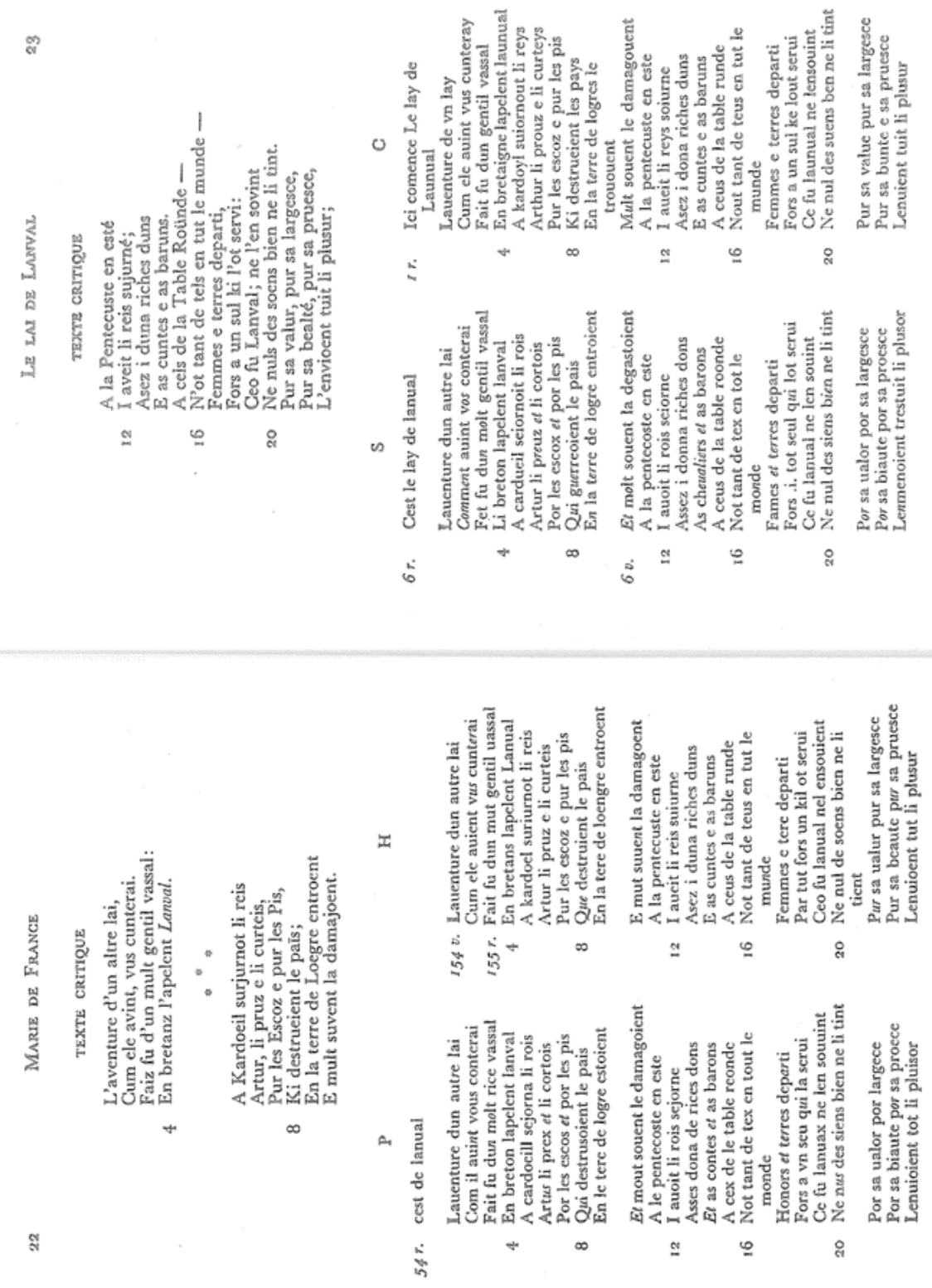

Fig. 6.1-6: The opening of Lanval in Jean Rychner's edition (1958). Manuscript $H$, regarded as the best, is London, British Library, Harley 978 (thirteenth century). For a full list of the other manuscripts, see the introduction (Rychner 1958, 7). 
orthography. Above them is the critical text established by Rychner, based on these four manuscripts and rendered in a unified orthography. This is an instructive example, in which Rychner details the genealogical recensio of the four manuscripts and the orthographical choices made. It should be added that this type of editing is best suited for short texts in a limited number of manuscripts and preferably in verse (here, octosyllabic). Rychner (1968) later edited the entire corpus of lais by Marie de France, and in this edition Lanval occupies 21 out of a total of 191 pages. A similar consideration applies to the exploratory editions of the Canterbury Tales by Peter Robinson and colleagues. The edition of The Wife of Bath's Prologue contained diplomatic transcriptions of all manuscripts as well as digital images of them (Robinson 1996b). There was, however, at this stage of the project, no critical text. For the further development of the digital editions of the Canterbury Tales, see section 6.3.3.3 below.

For mediaeval text genres with complex text traditions, other types of editions may also be relevant, and they may in fact combine the two perspectives outlined here. The approach can be genetic (reconstructing different stages in the development of a text), synthetic (establishing a text that is representative of certain strands or selected groups), or representative (presenting a synthesis of a text tradition). For a discussion and examples of these types, primarily based on the editing of classical texts, see Göransson (2016).

\subsubsection{Textual display}

There are a few aesthetic considerations for editions which have practical implications. With reference to printed editions, some editors would ask for a "clean text", even to the point of relegating notes and apparatus to an appendix in the edition. In these editions, the text can be read without other distractions than those chosen by readers when they decide to check if there are any comments on or variants for a passage in the text. This presentation was advocated by the influential American scholar Fredson Bowers (see Tanselle 1972, 45-46). It probably makes sense for editions of post-mediaeval texts that are being read for their own sake, that is, for the literature studied by Bowers and Tanselle. Texts that are based on a stemmatological recensio seldom fall into this category. One can envisage a spectrum from scholarly, technical editions, often with multiple and large apparatuses, to smooth and clean-looking reading editions addressed at a broader audience. The experimental edition of Lanval by Jean Rychner (1958) sits at the scholarly end, even though it is designed with an intuitive layout, while his general edition of the entire collection of lais by Marie de France (1968) is at the other end. What most scholarly editions seem to agree on is the typographical principle that readings in the text should be linked to the apparatus by line numbers, not by footnotes (although there are some notable exceptions, such as the Monumenta Germaniae historica). Even if there are one or even more apparatuses at the bottom of the page and there are various refer- 


\section{8}

DORLAKS SAGA AC

figh. ok ymna Jefu noltra redempcio. ok let pat pegar par a finna at hann hugfadi iafnan til peirar lausnar er gud hafdi leyft mann 42 kynid ok fanna aft vid gud ok menn Girnd eylifrar fọlu ok famuiftar vid gud. Otti doms dagf ok hingat kuoma fkaparans. at dęma um allt mannkyn. petta allt bodar peffor ymni. pa fonc hann Gregorius 45 bọn a medann hann klæddi sik ok par eptir hinn fyrfta pfalm or pfalltara. ok let ser alldri or hug ganga pau heilrọdi er $\mathrm{j}$ pfalminum ftanda. at fa er folll er æigi gengr eptir o radum ok eigi fam pyckir 48 illa luti med syndugum ok æeigi dọmir ranga doma. ok jafnann geymir guds laga. enn er hann kom til kirkiu. fonc hann fyrft lof heilagri prenning. eptir pat lofadi hann med fongum pa heilaga s1

C.4.4. eptir pat] sijdann $C^{6}$. er] $\div C^{2.4 .6} . \quad 41$ tigh] Herefter er teksten $i C^{3.4 .6}$ saa afvigende, at den trykkes for sig selv, se nedenfor. 43 kynid, "something seems to be missing here" OrIsl.

Efter 41 ligh har resten af kapillet folgende form i $C$. Tekst: $C^{3}$. Varianter: $C^{4.4}$, i l. 35.41 ogsaa $C^{7}$ :

26v Epter pad saung hann hymna. Iesu nostra redemptio. og liet hann pa pegar afinna, ad hann var onguo pui af huga er hann vaknadi, sem hann purfti ad hafa. Lausnenne fyrst er gud leysti oz, og ăstinne 3 er hann syner oz $\mathrm{j}$ huoruetna, girnd peirre er oz hæfer ad girnast til eilyfrar samvistu med gude. Epter pad las hann Gregorius bæn, medann hann för $\mathrm{j}$ klædi syn, og hann song pann psalm fyrstan 6 huorn dag sem fyrstur er j psalltara, og er pad audsyntt, hue varfær hann villdi vera $\mathrm{j}$ synu lyfe ä huorium deigi, sem sä psalmur bodar, ad sa sie sæll sem ey geingur epter oradum, og ey sampycker vm 9 jlla hlute vid synduga menn og hann bindur sig ey $\mathrm{j}$ rongum dömum.

1 saung-hymnal ymnann $C^{6} . \quad$ og] $\div C^{6} . \quad 2$ pa pegar] pad pegar pă $C^{6}$. af] fra- $C^{6}$. er] pegar $C^{6}$. $3 \mathrm{sem}$ ] er $C^{6}$. Lausnenne fyrst] pvi hann mintist fyrst lavsnarinnar $C^{6}$. oz] + undan fiandans vallde $C^{6}$. 3-5 astinne - gude] histar peirrar sem hann veiter mannkyninu $C^{6}$. 5 -vistu] -vista (1) $C^{4} . \quad 5-6$ Epter - song] Medann hann klæddist sỏng hann Gregorius bæn, pă sòng hann $C^{6}$. 5 hann] hanz (1) $C^{4} .{ }^{6}$ fyrstan]+hann (1) $C^{4} . \quad 7$ huorn dag] $\div C^{6}$. fyrstur er] fyrst stendur $C^{6}$. huel huad $C^{4}$, huorsu $C^{6}$. 9 sie] er $C^{6}$. ey $\left.^{1}\right]$ ecke $C^{4}$. -pycker] -pyckist $C^{6}$. 10 hann - ey] ei bindur sig $C^{6} .11$ pa] $\div$

Fig. 6.1-7: Porláks saga helga, an Old Icelandic bishop's saga, in the edition by Jón Helgason $(1978,72)$. This was the second volume of his basically Lachmannian edition; see figure 6.1-5 above for an extract from the first.

ences in the margin, the text block, if nothing else, should look clean. The example page in figure 6.3-5 in section 6.3.2.2, below has abundant information in the margins and the apparatuses, but manages to keep the text clean - or at least fairly clean. It cannot be denied that there are some editorial sign s that creep into an otherwise clean text, such as square brackets, angle brackets, asterisks, and obeli. The usage of these signs varies across editorial traditions and is not fully harmonised. While the Old Norse tradition of editing makes do with a limited set (see the overview in Haugen 2007, 118), there are more elaborate systems, perhaps most developed in the editing of epigraphical texts (see Dow 1969, with bibliography).

Jón Helgason's 1978 edition of bishops' sagas (see fig. 6.1-7) is an example of a scholarly edition in which the text is displayed synoptically on a split-level 
page, each version having its own apparatus. It is a far cry from the highly complex editions of, for example, the New Testament (as patiently explained in K. Aland and B. Aland 1989), but it is nonetheless located squarely at the scholarly end of the spectrum. For a reading edition of this selection of bishops' sagas, one has to turn to the recent edition of Byskupa sögur by Ásdís Egilsdóttir in the Íslenzk fornrit series (2002). This might be regarded as a kind of outreach edition, aimed at a broader audience, compared to the ascetic 1978 editor's edition by Jón Helgason.

\subsubsection{Textual unity}

Manuscripts usually show some internal variation in their orthography, even in the works of the most reliable scribes. This is especially so in the vernaculars, where the language in question sometimes developed considerably in the course of the textual transmission of a work. One should remember that the scribes did not have access to grammars or dictionaries, but had to rely on their internalised orthography, which from time to time was in conflict with the orthography of the exemplar. The external variation - that between manuscripts of the same work - was potentially even greater. This would almost always be the case when a sufficient amount of time had elapsed between the production of the manuscripts, perhaps several centuries, but it would also be the case for contemporaneous manuscripts from different regions.

Returning to Paris's dichotomy of the constitution des leçons, discussed at some length in section 2.3.2 above, and the constitution du langage, the latter approach deserves further discussion. It may be seen as a vernacular problem, but orthographical faithfulness is also debated among classical scholars; see, for example, the "vernacular" position of Hans Helander (2001, 5-44) and the critical comments by Heinz Hoffmann (2001, 51-58). No editor would claim that his or her edition is unfaithful to the sources, but there is a span from an extremely close rendering of a source to a fully regularised rendering, analogous to the span from narrow to broad transcriptions in phonology. Assuming that the edition is based on a single document, as in the editing of a complete codex unicus, for example, the editor still has to face two types of orthographical regularisation.

(i) Internal regularisation: introducing consistent use of graphemes to record the underlying phonological system as well as consistent morphological forms within the document. If an Old Norse scribe generally writes "lond" and "landum" (nom. and dat. pl. of land, nt., "land"), but occasionally slips to "londum" (with $u$-mutation of $a>0$ ), the editor might decide to regularise the latter "londum" to "landum" for the sake of orthographical consistency. This would be in keeping with the Old Norwegian provenance of the text, as witnessed by the distribution of $u$-mutation in it. Furthermore, if the source generally has the dative singular form "armi” (of $a r m r$, m., “arm”) but offers an occasional "arm” (possibly reflecting a 
merger of dat. armi and acc. arm), the editor might want to reinstate the ending $-i$, thus correcting "arm" > "armi". Due to the widespread scribal variation in Old Norse, this type of inconsistency is common. It is not really a mark of scribal sloppiness, but rather a reflection of conflict between the linguistic norm of the exemplar and that of the scribe, as occurred when an Icelander copied a Norwegian exemplar. He might, for example, struggle with making the distinction between /æ:/ and /ø:/, which was kept in Norwegian but merged to /æ:/ in Icelandic, as in bǿn, f., "prayer” > bæn and mǽla, vb, "speak" > mæla. In other words, the scribal variation reflects linguistic developments in time and space, and it is for the editor to decide whether the edition should reflect this faithfully or whether he or she would like to present the text in a consistent orthography, true to the time and locale of its production, but cleansed of accidental variation.

(ii) External regularisation: introducing consistent orthography and morphology according to a norm outside of the document itself. Fortunately, at least for editors, the Old Norse language (i.e. Old Icelandic and Old Norwegian) has a well-defined and generally accepted orthography for mediaeval texts. This was established by scholars in the nineteenth century and it has been used ever since in a large number of editions, especially those aimed at beginners and a general audience, and also in grammars and dictionaries of the languages. Other vernacular literatures do not offer the same standard orthography, although dictionaries and grammars do have a normalising effect on the conception of the language. The creation of a standard orthography for Old Norse was greatly helped by the fact that Icelandic morphology has hardly changed between the earliest recorded documents in the twelfth century and today. There has been phonological development in Icelandic, to be sure, but this is not always reflected in the written forms; or, if it is, the changes can be inferred by simple rules, such as the addition of an epenthetic and easily identifiable vowel in words like ungr, adj., "young” > ungur. The closely related languages Swedish and Danish have seen comparatively dramatic changes in phonology and morphology, so no standard orthographies have been developed, and editions usually follow the source fairly closely, including internal variation. Norwegian has also seen similar changes to those of Swedish and Danish, but they metaphorically ride on the back of Icelandic; Norwegian can use the same standard orthography for its mediaeval sources, at least up to around 1400, as Icelandic.

In the introduction to the Alexis edition (Paris and Pannier 1872), Paris spends a considerable amount of energy on establishing an orthography suitable for the earliest of the four versions of the legend. The original, $O$, of this version was probably conceived in Normandy around 1040 and is preserved in several later manuscripts. The best of these is Hildesheim, Dombibliothek, St. God. Nr 1, named $L$ by Paris after the abbey of Lambspringen near Hildesheim. It was written in England, though, and dates from around 1150, well after the Norman conquest. There is some orthographical vacillation in the manuscript, which Paris attributes to the fact that it was copied in England: 
Le scribe était assez intelligent et s'efforçait évidemment de reproduire avec fidélité le texte qu'il avait sous les yeux; mais il n'est arrivé, en ce qui concerne les formes des mots, qu'a une hésitation perpétuelle entre celles de son modèle et celles qui avaient prévalu de son temps et dans son pays. (Paris and Pannier 1872, 3)

[The scribe was quite skilful, and evidently tried to faithfully reproduce the text before his eyes; however, regarding the forms of words, he could not get beyond a perpetual hesitation between those of his model and those which prevailed in his time and in his country.]

This is the crux of vernacular transmission everywhere: the conflict between the exemplar's linguistic norm and that of the scribe. When editing the Alexis legend, Paris was looking for no less than the nobility of the French language of the time, essentially true to Latin and reminiscent of contemporaneous architecture:

Elle n'était pas encore embarrassée de cet insupportable attirail de particules oiseuses qui sont venues l'encombrer depuis; elle avait gardé du latin une ampleur de mouvements qui faisait ressortir encore la grâce qu'elle avait en propre. La langue de cette époque me rappelle ces belles églises romanes construites sur le sol de France et de la Normandie par les hommes même qui la parlaient. (Paris and Pannier 1872, 135)

[The language had not yet been muddled by the unsupportable paraphernalia of idle particles which have since encumbered her; she had retained from Latin a breadth of movement which brought out the grace she had of her own. The language of that time reminds me of those beautiful Romanesque churches built on the soil of France and Normandy by the very men who spoke it.]

Other editors of a reconstructive inclination may have less ambitious aims, but they are faced with the same textual variation and the challenge of untangling it so that they can derive the earlier forms from the later ones. In the edition of the earliest version of the Alexis legend, Paris decided to follow manuscript $L$ in most cases, after having performed an inductive analysis of the French language of the time. In his "Critique des formes", he detailed phonological and morphological properties over no fewer than 112 pages (Paris and Pannier 1872, 27-138).

For Latin, and particularly neo-Latin texts, there are similar considerations in the debate between Helander (2001) and Hofmann (2001), as pointed out above. Luc Deitz, who is a committed supporter of orthographical normalisation, cites neo-Latin examples such as partius, moestus, and hyemps for "classical" forms like parcius, maestus, and hiems, and believes that they are "likely to cause endless, and needless, trouble even to advanced students of Latin" (Deitz 2005, 351). It has to be said that, from a vernacular point of view, this variation is minute, but the need for normalisation from a didactic point of view is undeniable - it may, for example, not be immediately obvious that a form like vuin in an Old Icelandic manuscript is equivalent to úvin, m. acc., "un-friend, enemy", or that piuuær in an Old Swedish manuscript would be pjúfr, m. nom., "thief”, in some normalisations (see Haugen 2018b, 67-71). The willingness among many Latin scholars to normalise contrasts with the practice in the editing of Greek texts in the Corpus Christianorum series Graeca (CCSG) series, as pointed out by Caroline Macé: 


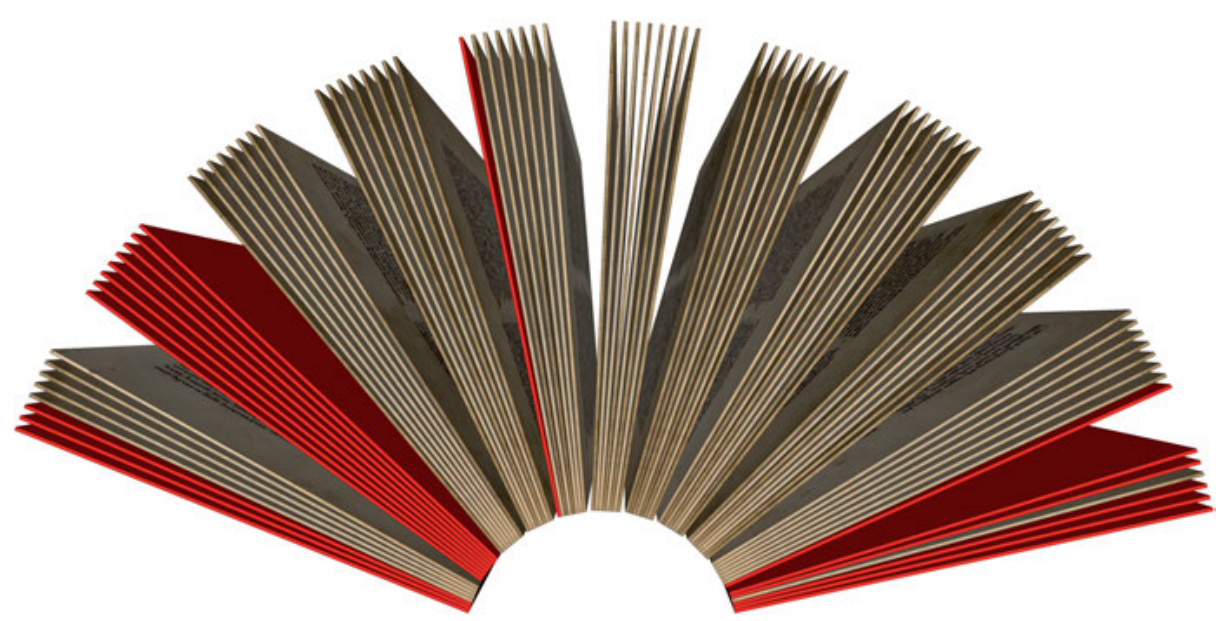

Fig. 6.1-8: Lost leaves (indicated in red) in the eleven gatherings of the main manuscript of Konungs skuggsjá, AM 243 b $\alpha$ fol (ca. 1270). Of originally 86 leaves, 18 have been lost, or approximately $21 \%$ of the text. Even so, this is the codex optimus for the work. Illustration by Nina Stensaker, Bergen, for this volume.

Jacques Noret, who was the reviser of the CCSG for about 25 years (1978-2004), expressed in several articles and in his editorial work the conviction that the only way to get a more accurate picture of Byzantine grammar, orthography, punctuation, etc. was to produce critical editions in which the practice of the manuscripts would be reproduced more adequately. (Macé 2016, 260)

In short, there is a general conflict between the didactic arguments for making texts easier to read and understand on the one hand, and the scholarly aspirations to faithfulness in the rendering of sources, even in critical editions, on the other.

A particular challenge concerns editions of texts which have a fragmented preservation such that no single manuscript can be used as the base manuscript for the entire edition, in contrast to the $L$ manuscript of the Alexis legend discussed above. The mid-thirteenth century Old Norwegian Konungs skuggsjá provides an instructive example. It is widely accepted that the earliest Norwegian manuscript, København, Den Arnamagnæanske Samling, AM $243 \mathrm{~b} \alpha$ fol (ca. 1270), is the codex optimus. Unfortunately, less than $80 \%$ of the once complete codex has been preserved, as shown in figure 6.1-8.

The latest edition of Konungs skuggsjá is the one by Ludvig Holm-Olsen (1st ed. 1945, 2nd ed. 1983), offering a strictly diplomatic approach. The full text of the work has to be supplied with the help of other manuscripts, in this case younger, Icelandic ones, as can be seen from the example in figure 6.1-9. Even for someone who does not understand the language, there is an obvious difference in the orthography of the first line, which follows AM $243 \mathrm{~b} \alpha$ fol, and the second line, which is based on a fifteenth-century Icelandic manuscript. Since the Old Norwegian manuscript breaks off at the end of this line, the editor had to resort to the younger Icelandic manuscript. 
First line in Norwegian of the 13th century, second line in Icelandic of the 15th century

en linklæðe pin pa skalltu lata gera afgoðo leræpti oc po litil æfni i. ger stutta skyrtu || pijna og lijn klædi pijn oll. Lat vel ætla iafnan godan mun stuttari skyrtu pijna en kyrtil.

Both lines in regularised Old Norse orthography of the 13th century

En línklæ̉ði pín pá skalt pú láta gera af góðu lérefti ok pó lítil efni í. Ger stutta skyrtu \| pína ok línklǽði pín ọll. Lát vel ǽtla jafnan góðum mun styttri skyrtu pína en kyrtil.

English Translation

(Your linen should be made of good linen stuff, but with little cloth used; make your shirt short, and all your linen rather light. Your shirt should be cut somewhat shorter than your coat.)

Fig. 6.1-9: Extracts from Ludvig Holm-Olsen's edition of Konungs skuggsjá (1983, 45). Expanded abbreviations are marked by italics.

For languages with an established and well-defined orthography, such as Latin, the editor may decide to regularise deviant orthography according to this standard as it has been established in grammars and dictionaries, in this case for classical as well as mediaeval Latin. Specific recommendations have been given by Klaus Sallmann in Normae orthographicae et orthotypicae Latinae (1990). As mentioned above, the same procedure is common in introductory and general editions of old Icelandic and Old Norwegian texts (see Haugen et al. 2019, chap. 10, and, in greater detail, Berg 2014). For some scholars, regularisation is primarily an aesthetic consideration, since it looks rather strange to have an edition which skips from one orthography to another, perhaps in the middle of a sentence, and back again. For linguistic scholars, however, it is a question of accountability, since it would be highly misleading to use, for example, regularised fifteenth-century Icelandic orthography as a witness to Norwegian language two centuries earlier. Editions like the one exemplified in figure 6.1-9 are thus a compromise between textual reconstruction and linguistic accountability.

\subsubsection{When Lachmann reigns in the introduction and Bédier in the text}

In section 6.1.2 above, Kristian Kålund's editions of Fljótsdǿla saga (1883) and Laxdǿla saga (1889-1891), and Henrik Bertelsen's edition of biðriks saga af Bern (19051911), were put forward as examples of reconstructive editing in the field of Old Norse. They did not, however, set a precedent (see Haugen 2019). When looking back on Old Norse editing during the last century or so, it can safely be said that the ideal of a full and transparent recensio of the manuscripts of a work is uncontested, above all in the Editiones Arnamagnæanæ published in Copenhagen since 1958 (see Louis-Jensen and Haugen in press). The founding father of this series, Jón Helgason, was unequivocal in this respect, also underlining the fact that younger and often neglected paper manuscripts should not be ignored (Giorgio Pasquali 
would surely have endorsed this principle). At a seminar organised by the University of Copenhagen in 1979, he gave a concise expression of his editorial programme:

The essential foundation for all close study of a text is a critical edition. One can demand of an edition that it presents, as far as is possible, an investigation of the whole manuscript tradition. The numerous young copies of older works must be examined because there is always the possibility that they derive from sources other than the surviving medieval texts. The result of such an examination is often that the younger copies prove to have no independent value, but this must nonetheless be demonstrated. The editor's aim must be to present as concisely as possible everything that the manuscripts themselves can tell us about a particular work's oldest form (that is to say, the oldest form we can establish which is not necessarily the original mould), while also giving an account of the work's history through the centuries. (Helgason 1979, 14)

This is a truly Lachmannian programme, if we allow ourselves to credit Lachmann with the later development of the genealogical method (see the important modifications in 2.3-4). There is hardly an edition in the Editiones Arnamagnæanæ which does not conclude with a stemma, and, even if the method as such is unnamed, it is the method of common errors which is the basis of recensio.

The surprising fact is that the stemma seems to be forgotten as soon as the editor moves from the introduction to the text itself. Rather than establishing the text with the help of the stemma, the edited text is more often than not a synoptic presentation, usually organised on split-level pages and with up to two apparatuses. When Jón Helgason returned to his edition of Byskupa sögur in a second volume, published in 1978, the reconstructive approach of the 1938 edition had become nonreconstructive, as shown in section 6.1.4 above. Bédier had, metaphorically speaking, suppressed Lachmann. On the page selected for figure 6.1-7 above, there are two manuscripts of widely different orthography - the upper one is in thirteenthcentury orthography, the lower one in seventeenth-century orthography. No single, critical text is offered.

This synoptic approach might be understood as a solution to a particularly difficult manuscript tradition for the bishops' sagas and thus as a deviation from the Lachmannian programme defined by Jón Helgason himself. However, since the initiation of the Editiones Arnamagnæanæ series in 1958, non-reconstructive editing had become the norm. There is no explicit discussion of this aporia in the text editions themselves, so the explanation can only be a matter of hypothesis. At least three textual properties seem to line up against the construction of a single critical text.

(i) Textual dynamics. While certain texts were copied faithfully and thus with little textual variation over time, other texts were copied by scribes who also revised, added to, and subtracted from the text according to their tastes or to the text's presumed audience. When textual deviations become too plentiful, it is no longer practical to record them in an apparatus of variants, and one must rather accept that versions have to be presented on their own, synoptically or sequentially, 
or that one version has to be suppressed in favour of another, presumably better version. Trying to build a critical text would mean that the editor would offer a text that never was.

(ii) Linguistic diversity. Where texts were copied over time and space and thus acquired new and distinct orthographies, selecting a single linguistic form over others would skew the display of the texts. This is a particular challenge for vernacular texts where variation is a result not of deviation, conscious or not, but of the historical development of language over time and across regions. In this situation, the editor risks offering a text that should be, rather than the texts that actually were.

(iii) The ravages of time. As pointed out above, the majority of manuscripts from the classical and mediaeval periods have been lost. Some estimates put the number as high as at least $90 \%$. This degree of loss has been arrived at by extrapolating from the recorded loss of early printed books, for which we have good catalogues (see Neddermeyer 1996; Olrik Frederiksen 1999; Guido and Trovato 2004, discussed under "2004" in 2.4.3 above). One inevitable consequence is that one or more families will be irrevocably lost, and furthermore that the remaining manuscripts will be more prone to bifurcation, as argued by Guido and Trovato (2004), or members of once large families may be reduced to outliers in the tradition, carrying less weight than they should have carried. It goes without saying that, in such a situation, the editor will be driven towards the codex optimus, and that the edition will be of the text that was, rather than of the text that could have been.

If these considerations are relevant to the practice of editing, they may help to explain the limitations of reconstructive editing in the face of textual variability. It is not the failure of the reconstructive programme as such, but the realisation that the textual material may sometimes be too complex or too fragmented to be dealt with by reconstructive editing. Of particular interest, perhaps, is the fact that a stemma is no guarantee of a correct constitutio textus in the edition in which it appears. Nor is an edition a prerequisite for the stemma; there are a number of stemmata published outside editions. What stemmata have in common is the fact that they are the result of a recensio of the manuscripts, to be used, or not, in the establishment of the edited text.

\title{
6.2 Text-critical analysis
}

\author{
Marina Buzzoni
}

In section 2.2, the principles of the genealogical method were treated and the process of text restoration was critically assessed. As the main technical terms and procedures are of a rather abstract nature, this section will introduce them together with practical examples that illustrate them. Whenever possible, an inductive approach will be used, aimed at developing skills and knowledge by working on real examples from historically transmitted texts. 


\subsubsection{Definition and terminology}

The expression "text-critical analysis" refers to the process of producing a critical text within the genealogical (or Lachmann's) method, also referred to as constitutio textus or restitutio textus (i.e. the restoration of the text as closely as possible to the original by the editor, see 2.2, 3.2 above; Tarrant 2016 speaks of “establishing the text”). In Paul Maas's handbook (1960, first ed. 1927), constitutio textus is not specifically defined, but it is associated with the overall editorial process: "Aufgabe der Textkritik ist Herstellung eines dem Autograph (Original) möglichst nahekommenden Textes (constitutio textus)" (Maas 1927, $1=1960,5$ ) [The business of textual criticism is to produce a text as close as possible to the original (constitutio textus)] (trans. Flower 1958, 1).

Consequently, the expression constitutio textus may be used in a broad sense to cover the whole process of textual criticism, which can be divided into the following phases:

- recensio, with collatio, followed by the establishment of a stemma codicum and examinatio of the variant readings;

- emendatio, that is, selectio, combinatio, and divinatio; and

- dispositio, the final stage of producing the critical edition, in which the text is laid out, apparatuses are created, and other complementary material such as an introduction, descriptions of manuscripts, and notes are incorporated.

On the other hand, other authors use constitutio textus in a stricter sense to refer to the phase of textual reconstruction which follows recensio (i.e. the comparison and evaluation of the witnesses) and includes selectio as well as emendatio, which, in this case, is synonymous with divinatio (see, among others, P. Chiesa 2002, 50-51, who is, however, well aware that these phases can be variously divided and labelled; see also Duval 2015, s. v. "emendatio", “établissement du texte”; Tarrant 2016, esp. 49$50,65)$. The following table summarises the major terminological differences still in use (further differences will be accounted for, when relevant, in the pertinent

Tab. 6.2-1: A comparison of the usage of terminology for the phases of text-critical analysis.

Text-critical analysis = constitutio textus

Text-critical analysis (e.g. in P. Chiesa 2002)

(whole process) (e.g. in Maas 1960)

\begin{tabular}{|c|c|}
\hline & collatio \\
\hline $\begin{array}{l}\text { recensio } \\
\text { collatio } \\
\text { construction of the stemma codicum } \\
\text { examinatio }\end{array}$ & $\begin{array}{l}\text { recensio } \\
\text { construction of the stemma codicum }\end{array}$ \\
\hline $\begin{array}{l}\text { emendatio } \\
\text { selectio } \\
\text { combinatio } \\
\text { divinatio }\end{array}$ & $\begin{array}{l}\text { constitutio textus } \\
\text { selectio } \\
\text { emendatio = divinatio }\end{array}$ \\
\hline
\end{tabular}


subsections; see e.g. 6.2.3). It should be noted, however, that, despite these differences, the core of the method remains the same (see also Stussi 2006, 14, esp. n9).

In what follows, terminology equating constitutio textus with text-critical analysis as a whole will be used (the left-hand column in table 6.2-1). Among the reasons for this is that the author of this section considers the process of recensio an early stage in establishing the text (like Tarrant 2016, 49), and selectio a specific act of emendation by judgement (see also Luiselli Fadda 1994, 183-242; Duval 2015, “s. v. selectio", in particular the remark on meaning 1) rather than simply a phase that precedes it. We shall now take a look at the stages that have been mentioned separately.

\subsubsection{Recensio}

The first step in the establishment of a text entails the identification and the systematic comparison of the witnesses transmitting that text, taking into consideration both the direct tradition (i.e. either complete or partial copies of the text) and the indirect tradition (i.e. translations, quotations, summaries; see 3.2). This is commonly called recensio. Such a recensio includes the preliminary identification of the witnesses ("heuristics"; see 3.1) and collatio (i.e. the comparative examination of the witnesses in order to identify the places where the texts differ, as described under 3.3). Usually, only a subset of these variant readings (namely, only those readings that can be considered "significant errors" - Leitfehler, both conjunctive and disjunctive) are used to determine the genealogical relationship between the witnesses. The examination of shared errors is a crucial procedure of recensio whose purpose is at least threefold: eliminating derivative manuscripts (codices descripti; see 2.2, 2.4), reconstructing the lost ancestors (internal nodes) from which the surviving ones descend, and finally drawing up a stemma codicum (see 2.2, 4.1-2, 4.5) representing the genealogical connections among witnesses.

\section{Example 1: The Heliand}

Here is a relatively straightforward example taken from the ninth-century Old Saxon poem on the life of Christ entitled Heliand [The Saviour]. We will focus on lines 1306b-1308a (= Taeger 1996, 52; see xxi for text-critical details) from song 16, telling of the Chieftain's instructions on the mountain; note that the use of italics in the edited text signals the interventions of the editor, who chose $M$ as his base manuscript.

Quað that ôc sâlige uuârin,

thie hîr uuiopin iro uuammun dâdi; 'thie môtun eft uuillion gebîdan,

frôfre an iro frâhon rîkia.'

1308a an iro frâhon rikea V; an iro rikia M; an them selbon rikie C

[He [Christ] said that those also were fortunate, who cried here over their evil deeds, "in return, they can expect the very consolation they desire in their Master's kingdom."] (trans. Murphy 1992, 46) 
In line 1308, the sense requires the reading transmitted by manuscript $V$ : "an iro frâhon rîkia" [in their Master's kingdom]; in fact, both the $M$ ("an iro rikia" [in their kingdom]) and $C$ ("an them selbon rikie" [in their own kingdom]) readings would attribute the "kingdom" to the repenting sinners rather than to God. We can therefore assume that $M$ and $C$ are in agreement in error - the error being basically the lack of frâhon (gen. sg. of the noun frâho, "master, lord"). We should recall here that only agreement in monogenetic errors is relevant from a genealogical perspective, since it offers clues for detecting innovation (secondary readings, or "errors") vs preservation (primary readings); and that, usually, only substantial readings (see 4.1.5) turn out to be useful, since formal readings (see 2.3.2) are more likely to be either accidental or polygenetic (on these topics, see also Stussi 2006, 9-16).

The assumption made about the $M$ and $C$ readings vs that of $V$ for line 1308a leads to different stemmatic possibilities depending on the interpretation of the origin of the error. If we think that it is more likely that the change from the reading transmitted by $V$ occurred only once, we are led to postulate a common ancestor of $M$ and $C\left({ }^{*} C M\right)$ that is not a source of $V$. That source could be either an independent one (fig. 6.2-1) or $V$ itself (fig. 6.2-2).

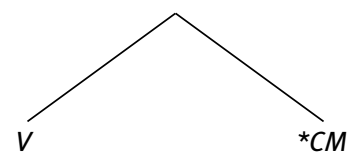

Fig. 6.2-1: Bipartite stemma with $V$ representing one independent branch and ${ }^{*} C M$ the other.

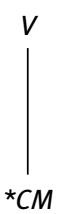

Fig. 6.2-2: Single-branch stemma with ${ }^{\star} C M$ deriving from $V$.

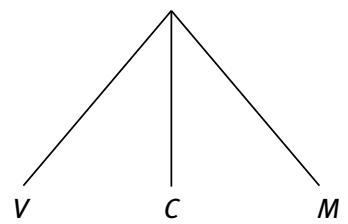

Fig. 6.2-3: Tripartite stemma with each witness representing an independent branch.

If, however, we think that it is more likely that the error was independently made twice in $M$ and $C$, we would propose a representation where $M$ and $C$ are not affiliated, as in figure 6.2-3. 
In order to decide between the possible options, we need more evidence: though relative probability favours the most economical hypothesis, that the error occurred only once, we require a number of instances in which $C$ and $M$ agree in error before concluding that they are stemmatically affiliated. In this case we are lucky, since a good number of such Bindefehler (conjunctive errors) - Taeger (1996, xxi) identifies twenty-three - support the first hypothesis, namely that $C$ and $M$ share a common ancestor against $V$.

We should now establish whether ${ }^{*} C M$ is (i) independent of $V$ or (ii) derived from it. The required evidence will be an error present in $V$ but not in ${ }^{\star} C M$, one that cannot be easily corrected (Trennfehler, or separative error). If we find such an error, it will be unlikely that ${ }^{*} C M$ derives from $V$; rather, it will be much more likely that ${ }^{*} C M$ represents a branch independent of $V$. A good candidate is line 1311a, where ${ }^{*} C M$ reads: "thie rincos, thie hîr rehto adômiad" [those fighting men who judged fairly here] and $V$ reads: "thie rincos, thie hîr rehto duomeat". The reading of $V$ is a clear mistake since it makes no sense and could not be easily restored by a scribe; on the contrary, the verb adômian, "to judge", transmitted by $C$ and $M$, enhances the meaning of line 1309a: "rincos, that sie rehto adômien" [those fighting men who wanted to judge fairly]. In fact, the anaphorical use of the same verb produces a circular effect in this passage (lines 1308b-1311a = Taeger 1996, 52):

Sâlige sind ôc, the sie hîr frumono gilustid,

rincos, that sie rehto adômien. Thes môtun sie uuerðan an them rîkia drohtines

gifullit thurh iro ferhton dâdi: sulîcoro môtun sie frumono bicnêgan

thie rincos, thie hîr rehto adômiad.

[Those too are fortunate who desired to do good things here, those fighting men who wanted to judge fairly. With good things they themselves will be filled to satisfaction in the Chieftain's kingdom for their wise actions; they will attain good things, those fighting men who judged fairly.] (trans. Murphy 1992, 46)

Although, in this example, the probability that duomeat is a trivial error is very high since the term makes no sense, it is not always easy to discriminate between an apparently wrong reading and a more difficult reading, that is, a lectio difficilior (see below). In fact, it is not uncommon that a scribal error creates a lectio difficilior or - conversely - that a lectio difficilior is taken as an error and therefore "corrected".

Returning to our question of whether ${ }^{*} C M$ is independent of $V$ or derives from it, in the light of what has been discussed so far we are led to grant ${ }^{*} C M$ independence from $V$, and inclined to prefer hypothesis ( $i$ ) over (ii). This conclusion is the result of judicious calculations of probabilities and close attention to all potentially relevant factors, including both form and substance of the variant readings - as shown by the adômian example - as well as elements of the whole manuscript tradition (for a comprehensive stemmatic hypothesis for the Heliand manuscript tradition, also including the $S$ and $P$ fragments, see Taeger 1996, xxiv, and Buzzoni 
2011, 104, where the most recently recovered fragment from Leipzig in 2006 is also integrated into the stemma).

This leads to a further important consideration, particularly relevant in a reconstructive perspective: the presence or absence of an archetype distinct from the original in the tradition (see 4.1.5). The existence of such an archetype can, in fact, only be ascertained if one can detect at least one "error" common to the whole tradition, thus proving the existence of an already modified copy, the archetype, from which the entire extant tradition stems. (The main characteristic of such "errors" is that they could not have stood in the original, for whatever reason.) To continue with the Heliand example, this is a case of a tradition in which an archetype has been postulated between the two branches $V$ and ${ }^{\star} C M$ (see fig. 6.2-1) and the original due to some errors that these branches apparently share (Taeger 1996, xxiv). On the other hand, the tradition of the Old English Sermo Lupi ad Anglos (see example 13 below) lacks an archetype distinct from the original (see Luiselli Fadda 1994, 213), and so do a good deal of other mediaeval Germanic texts. The situation is very different for texts from Antiquity: due to the hiatus in time between the original and the oldest manuscripts, an archetype is usually present. Establishing whether an archetype or the original has to be posited at the basis of a tradition is fundamental, as it changes the scope of the editor's interventions: an editor is entitled to emend the text of the archetype in order to get as close as possible to the original, but if there was no archetype, the agreement of either all or the majority of branches in the stemma yields an original reading that the editor has to live with and should not emend (see e.g. P. Chiesa 2002, 81).

\subsubsection{Examinatio}

Recensio ends with examinatio, that is, the analysis of the complete set of variants (and not only of the indicative errors) in order to ascertain whether the readings to be attributed to the reconstructed text can be chosen solely on the basis of the stemma, or whether there still remain some corruptions that can be corrected only by emendatio (see 6.2.3).

Since a stemma, as shown in figures 6.2-1-3 above, is a working hypothesis in that it represents the best choice among a set of possible options, neither the process nor the results of examinatio are always straightforward. One should also consider the fact that stemmata can come in a wide variety of configurations (see 4.1), some of which are especially complex, in particular those shaped to represent contamination (see 4.4), a circumstance which renders the identification of original or archetypal readings extremely difficult. Some theoretical examples are provided here to illustrate some general principles of how to choose the readings most likely to be archetypal or original; these will be followed by real examples. The case of intra-stemmatic contamination was discussed in extenso in section 4.4, but is worth recalling here. 


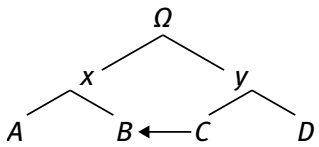

Fig. 6.2-4: A hypothetical stemma displaying intra-stemmatic contamination ( $\Omega$ indicates the archetype).

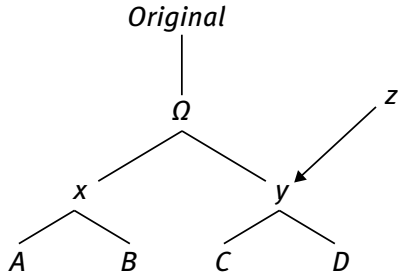

Fig. 6.2-5: A hypothetical stemma showing extra-stemmatic contamination ( $\Omega$ indicates the archetype).

This stemma in figure 6.2-4 represents an instance of horizontal transmission, in that the copyist of $B$ draws not only on the a n tig raph within the same branch of the stemma (i.e. the lost witness $x$ ) but also on an extant witness that belongs to another branch (i.e. $C$ ). Therefore, $C$ is said to have contaminated $B$. Technically speaking, the readings that only $B$ and $C$ have in common against the other witnesses are lectiones singulares (see 5.2.3.1), which are unlikely to represent the readings of the archetype (for more complex situations, see, among others, 4.4 above; Avalle 1972a, 70-86; Timpanaro 1981, 143-144; Luiselli Fadda 1994, 220-222; Trovato 2017, 129-130).

Contamination may also be extra-stemmatic (already mentioned in 2.4 .3 and shown in fig. 6.2-5). In this case, we assume that the copyist of $y$ included in the text some readings (Fremdlesungen; Fränkel 1964, 78) taken from an external lost source - either a lost branch of the same textual tradition ("extra-archetypal contamination"; Trovato 2017, 134), or a different textual tradition altogether (Timpanaro 1981, 143; this second possibility, of which Timpanaro was well aware as early as the mid-twentieth century, is often overlooked by scholars, even though it is frequently present in real traditions, as shown in examples 2 and 3 below). The lost source is represented in the stemma by $z$. In this simple configuration, the unique readings shared by $C$ and $D$ cannot be ascribed with certainty to the text of $y$ copied from the archetype $\Omega$ as they may also come from the external contaminating source (see Avalle 1972a, esp. 78, point 4; Luiselli Fadda 1994, esp. 221, point (b)). In other words, a reading which is shared by $C$ and $D$ alone may come from the archetype $\Omega$, but it could also go back to $z$. In the latter case, that reading has no reconstructive value for the archetype $\Omega$. In fact, in such a constellation, the readings with a reconstructive value are only those which $x(A+B)$ and either $C$ or $D$ (or both) have 
in common, since only these readings are attested in both branches of the tradition and therefore ascribable with certainty to the archetype $\Omega$. In some cases, the readings deriving from the external source might come from higher up in the stemma than those of the archetype itself and thus be potentially useful for reconstructing the original.

\section{Example 2: The Mahābhārata}

In real textual traditions, the situation can be even more complex, especially when oral tradition plays an important role in the transmission of a text. Vishwa Adluri and Joydeep Bagchee, in their work on the Old Indian epic poem Mahābhārata (Adluri and Bagchee 2018), claim that extra-stemmatic contamination can be of two types, namely contamination into an ancestor of the archetype, or "hyperarchetypal contamination", and contamination of an extant source from a no-longer-extant source, or "extra-stemmatic contamination in the proper sense". In the Mahābhārata, extrastemmatic contamination is often present, especially due to the fact that an older oral epic tradition existed alongside the written one. Elements of this older oral epic have survived beyond its alleged Brahmanic redaction, and scholars have explained this fact in two ways: either the Brahmanic redaction was not complete, and thus episodes and narratives from the oral epic tradition present in the older "kșatriya stage" were preserved, or the older epic tradition survived at the margins of Brahmanic society and occasionally caused the introduction of kșatriya elements into the epic. The first view involves an instance of hyperarchetypal contamination (contamination of the original epic with a source prior to the formation of the archetype). The second view accounts for the occurrence of oral material in the Mahābhärata tradition by invoking extra-stemmatic contamination in the proper sense, and therefore the existence of a parallel tradition or transmission alongside the written one.

\section{Example 3: The Anglo-Saxon Chronicle}

The Old English text of the Anglo-Saxon Chronicle is transmitted in seven manuscripts labelled with the letters $A-G$ : $G$ is clearly a codex descriptus derived from $A$, and therefore can be left aside; $B$ is very close to $C$, both having been copied from the same ancestor; and $F$ is an epitome of $E$. The complex relationships between the extant witnesses, also including some Latin texts that have a version of the Chronicle among their sources - in particular Asser's Life of Alfred, Æthelweard's Chronicon, and the Annals of St Neots - have been variously interpreted and represented by scholars. However, two features in particular seem to point to the fact that the compiler of the Latin Annals of St Neots was using a copy which must have preceded all the other Chronicle witnesses: first, at lines 642 and 672, the form "koenuualch" for the name of a king is older than the "cenwalh" of all the vernacular texts; and second, the Annals lack the chronological dislocation between the years 756 and 842 shared by all the other manuscripts. Æthelweard's Chronicon, 


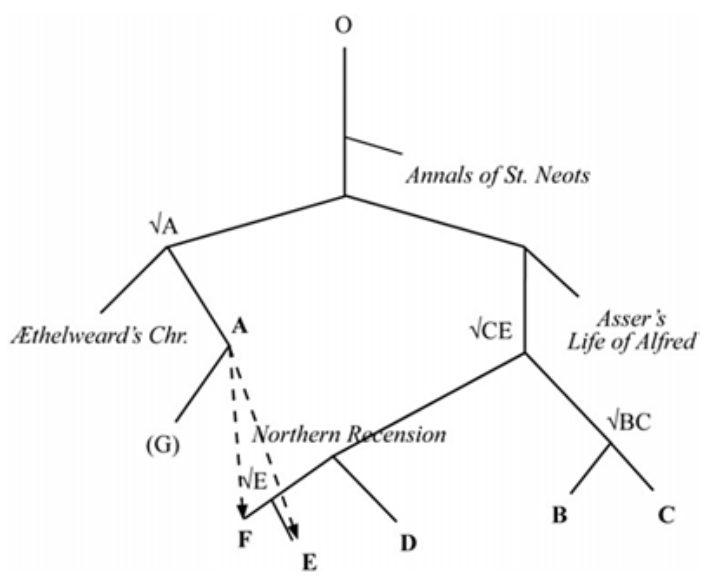

Fig. 6.2-6: Stemmatic proposal for the Anglo-Saxon Chronicle witnesses. Source: Buzzoni et al. (2016, 655).

contrary to all the surviving witnesses and Asser's Life of Alfred, has not lost a whole sentence from the annal for 885 by homoeoteleuton (or eye-skip; see 4.3.2) and does not have the additions also absent in $A$, which means that the Chronicon belongs to the same branch as $A$, though it is, in some respects, closer to the original. As for Asser's Life of Alfred, Dorothy Whitelock $(1979,118)$ claims that, since there are passages where Asser's text, Æthelweard's Chronicon, and $A$ agree against $B, C, D$, and $E$, these four manuscripts of the Chronicle can be taken to descend from a common version which contained several new features $(V C E)$. Due to their closeness (e.g. they agree in entering the portion called the "Mercian Register" as a whole block of annals, 902-924, and they share the annals for 957, 971, and 977, which do not occur anywhere else), it is generally assumed that $B$ and $C$ are copies of a common ancestor $(V B C)$. Finally, $D$ and $E$ agree against all the other witnesses in their inclusion of an early set of annals known as the "Second Northern Group" (901-966), which contains material of northern interest drawn mainly from Bede's Historia ecclesiastica gentis Anglorum and from additional northern annals. It is generally assumed that they descend from a common ancestor, from which $E$ seems to be at two removes (Cubbin 1996, liii). A stemmatic proposal (fig. 6.2-6) that captures the agreement of $B, C, D$, and $E$ as opposed to $A$, as well as the strong contamination between the $A$-branch and the $E$-branch of the Chronicle tradition, has been put forward by Marina Buzzoni (Buzzoni 2001, 42; Buzzoni et al. 2016; in fig. 6.2-6, intra-stemmatic contamination is marked by dashed lines and the direction of contamination is represented by arrows). The stemma also captures the relationships with the abovementioned Latin texts that have a version of the Chronicle among their sources.

Sometimes, computer-assisted stemmatology (see 5.1) can contribute to shedding new light on old problems. The graph obtained by applying NeighborNet (see 4.4.6.2, 5.5.8, 8.1) detects a further contamination path from $A$ to the $B C$-branch, 


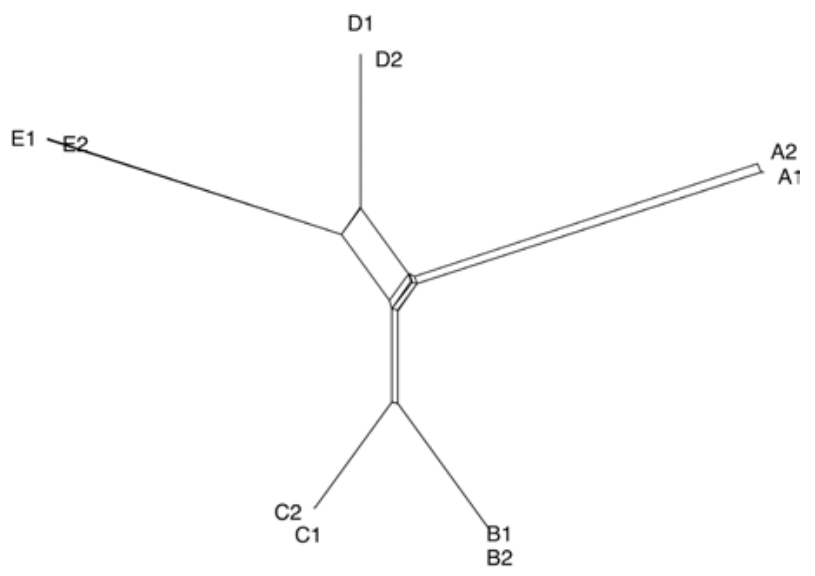

Fig. 6.2-7: NeighborNet graph of the Anglo-Saxon Chronicle witnesses (with the exception of the bilingual $F$, which bears entries in Old English and Latin). Source: Buzzoni et al. (2016, 662, fig. 6.2-7).

usually neglected in traditional stemmata, despite the fact that it is supported by textual data. $B$ and $C$, in fact, share "a few supplementary notes" (Taylor 1983, xxxv) drawn from the ancestor of $A$ specifically for the annals for 957, 959, 971, 976 ( $C$ only), and 977 . The contamination between $A$ and the $B C$-branch is clearly recognisable in figure 6.2-7, as the network linking the branches under inspection shows.

\section{Example 4: The Minnesänger}

Contamination can also move both ways. Such reciprocal contamination, represented below, leads to situations that can assume the shape of a ring, as shown in figure 6.2-8.

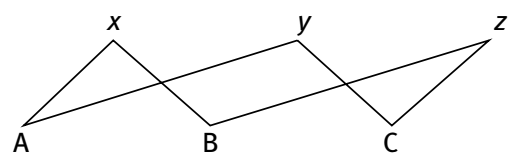

Fig. 6.2-8: A relationship between witnesses demonstrating reciprocal contamination.

In a case like this, where $A$ and $B$ draw on $x, A$ and $C$ draw on $y$, and $B$ and $C$ draw on $z$ (reciprocal contamination), no genealogical reconstruction is, in fact, possible (Avalle 1972a, 104-105), and the relationship between the witnesses can perhaps be better represented as a ring, which, in contrast to a traditional stemma, lacks a temporal dimension. This is called a conflation ring (Dearing 1967, 291; 1968, 553), as shown in figure 6.2-9. 


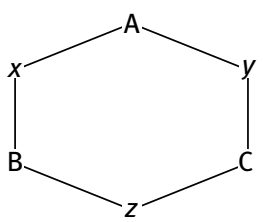

Fig. 6.2-9: A schema for a conflation ring.

Some scholars claim that this representation is suitable for illustrating the connections between three Middle High German manuscripts that transmit lyric compilations of Minnesänger, namely the Kleine Heidelberger Liederhandschrift ( $A$; Heidelberg, Universitätsbibliothek, Pal. germ. 357, late thirteenth century), the Weingartner Liederhandschrift (B; Stuttgart, Württembergische Landesbibliothek, H.B. XIII, poet. germ. I, early fourteenth century), and the renowned Codex Manesse, or Große Heidelberger Liederhandschrift ( $C$; Heidelberg, Universitätsbibliothek, Pal. germ. 848, made in Zurich in the first third of the fourteenth century, in all probability under the patronage of the Manesse family). The mutual relationships among these witnesses are still a matter of debate, but we are pretty sure that $B$ and $C$ share a common ancestor $(z)$, and that $C$ partially draws on a source of $A$ (Frühmorgen-Voss 1975 , 57-88), or perhaps on two different redactions of $A$ (Sayce 1982, 56; Luiselli Fadda 1994, 222).

In addition to contaminated traditions, overabundant traditions can also be difficult to handle. In traditions that can hardly be assessed in their entirety due to the abundance of witnesses, philologists may decide to select a number of loci critici to establish the stemma. A locus criticus (or selectus) is a portion of the text in which the amount of significant errors between the various witnesses is particularly high (see also the notion of "variant location" in 3.3); the alternative adjective selectus alludes to the fact that the passage has been chosen for critical purposes. Although the expression seems to be first attested in the 1970s (Balduino 1979, 29: "il concentrarsi di errori significativi”), both Maas $(1927,13)$ and Pasquali $(1934,55-56)$ had already introduced the similar notion of "collation by samples" ("collazione per campioni”). Richard Tarrant similarly speaks of "selective collation" $(2016,56)$. The most important editions of Dante's Divina Commedia are based on the scrutiny of loci critici: 396 of them from 200 witnesses in Barbi's 1891 preparatory work (known as “Barbi's canon”), and 477 in Petrocchi's edition (1966-1967; for further information, see Brandoli 2007); in his 2001 edition of the Commedia, Federico Sanguineti goes back to Barbi's canon and extends the collation to more than 500 witnesses. There are, of course, some hurdles and risks in this procedure, especially when a new collation is entirely based on the results of previous collations assembled using samples (see, among others, Vàrvaro 1970, 574).

As stated before, once the stemmatic configuration has been determined, the process of examinatio goes on to ascertain whether it is possible to establish some either archetypal or original readings only on the basis of the stemma, using a simple calculus of shared readings, namely by applying the majority principle to inde- 
pendent branches (see esp. 2.2-3). Roughly speaking, this is more likely to happen, or is more easily recognisable, in a closed recension, and far less likely - if not completely impossible - in an open recension (Pasquali 1934, 126; the latter is also called a "non-mechanical recension" by Timpanaro 1981, 101; see esp. 2.4 above; see also 4.4 above). What follows are a few examples of selecting readings on the basis of the stemma.

\section{Example 5: "mund" vs "mûə”}

A simple example of choosing a reading according to the stemma can be found in the Heliand. At line 1293b (= Taeger 1996, 51), the reading "mund" [mouth], which is shared by $M V$ against the $C$-reading "mûð" (the Ingvaeonic cognate form) has been preferred by scholars since it occurs in both branches of the stemma (see fig. 6.2-1 above):

mildi an is môde, endi thô is mund [C: mûð] antlôc.

[mild in his heart; and then he unlocked his mouth.] (my trans.)

\section{Example 6: Jean Renart's Lai de l'ombre}

Another interesting case study is offered by the manuscript tradition of Jean Renart's Lai de l'ombre (end of the twelfth or early thirteenth century). The text is transmitted in seven main witnesses mostly going back to the thirteenth century and labelled with letters from $A$ to $G$. As a starting point for the stemmatic analysis, we can postulate the very well-known hypothesis put forth by Gaston Paris in 1890 (see Bédier 1928, 167; Trovato 2017, 290), who proposed the tripartite stemma reproduced in figure 6.2-10. This stemma has been discussed frequently (see Trovato 2017, 292-297), but this is not relevant for our purposes here.

At line 217 of the Lai, the varia lectio (the entirety of variation at this one locus) reads as follows.

\footnotetext{
$A B: \quad$ en son penser et en sa voie

$D E$ : a son penser et a sa voie

$C G$ : celant son penser et sa voie

$F$ : a ses amours et a sa joie
}

F's reading is a unique reading (lectio singularis), isolated at the bottom of the stemma; therefore, it is highly unlikely to represent the reading of the original. $A B$ 's reading can be traced back to their common ancestor, namely $x$. Similarly, $C G$ 's reading can be taken to come from $y$. The only reading that is attested in two branches of the tradition is that transmitted by $D$ and $E$ ("a son penser et a sa voie"), which thus represents the best candidate with which to restore the line of the origi- 


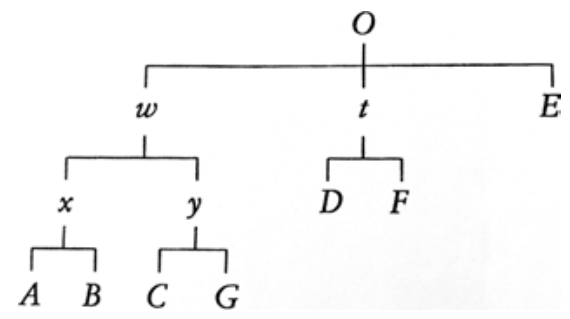

Fig 6.2-10: Gaston Paris's tripartite stemma for the Lai de l'ombre, as reshaped by Bédier (1928, 167).

nal - of course, this conclusion holds only if we give credence to the stemmatic configuration in figure 6.2-10.

\subsubsection{The use of indirect traditions}

On the use of indirect traditions to establish the readings as close as possible to the original, see sections 3.2 and 6.2.3 (example 7). On a more general level, it can be added here that the hazards of textual transmission may result in the indirect traditions having a central role compared to direct ones. For instance, the indirect tradition surviving in mediaeval manuscripts from what we might call "peripheral” European areas like England or the Nordic countries (see Pasquali 1952, 174-176) can be central to the retrieval of either completely lost texts or genuine readings of preserved traditions. For instance, many Latin codices reached England very early (i.e. the late sixth and seventh centuries), brought there by missionaries from Italy. Once in England, the texts contained in these codices were often translated or manipulated in various ways. The indirect tradition offered by these pre-Carolingian insular sources can be of great importance in establishing a number of readings of the original Latin texts that have otherwise been completely lost, as was convincingly demonstrated by Anna Maria Luiselli Fadda (1998) in her study of the indirect tradition of the Vita Fursei. A further paradigmatic example is offered by the Old Norwegian prose translation of La Chanson de Roland (usually labelled as $n$ ) which appears as the eighth chapter of a collection entitled Karlamagnús saga and is pretty close to the most authoritative witness of the Chanson, Oxford, Bodleian Library, Digby 23. As remarked by Paul Aebischer (1954) and Eyvind F. Halvorsen (1959), as well as by Cesare Segre in his 1971 groundbreaking edition of the text, $n$ occupies a relevant position in the stemma and can therefore be used to determine a number of good variant readings of the $\beta$-branch (Segre 1971; see also Avalle 1972a, 23, and, on a similar topic, Willert Bortignon 1993).

When the tradition consists of three or more independent branches (as in fig. 6.2-3), the agreement of the majority of branches will usually give the archetypal or the original reading. However, especially in bipartite stemmata (see 4.1), difficulties may arise when the editor has to decide between readings that have equal stemmatic value (stem matically undecidable variants, in Italian called varian- 
ti adiafore). In such cases, the reading of the archetype or of the original can only be ascertained by judgement, that is, by weighing up the relative merits of the variants, as will be shown below in section 6.2.3.

\subsubsection{Emendatio}

In the broader perspective of constitutio textus adopted here, emendatio (see 2.2, 3.1, 4.1) is the second major step in textual restoration, whereby the editor tries to restore "archetypal" or "original" readings where no mechanical choice is possible (see 2.1), that is, in those cases where examinatio cannot yield an unambiguous result. This can be done by judgement, either according to internal criteria (selectio; see 2.2) or conjecturally (divinatio). As far as the actual text-critical procedure is concerned, selectio precedes divinatio: the latter is performed only when the results of the former are not decisive for establishing all the readings to be included in the critically assessed text which is potentially the original.

The most common internal criteria according to which the selection between readings of equal stemmatic value is carried out are lectio difficilior (potior), "the more difficult reading is the preferable reading" (see 2.1, 2.4); us us scriben$d i$, "the practice of the author"; and other peculiarities ascribable to the potential author(s) of the work, for example the language variety they presumably used or the alleged period of composition of the work. Sometimes, the reconstructed reading can also be obtained by combining variants that are only partially correct, that is, by combinatio. Some scholars consider combinatio a subtype of divinatio; others see it as in between selectio and divinatio.

As for divinatio, two slightly different meanings of the term can be singled out. Following the terminology adopted in this section, divinatio is one of the three main operations which characterise emendatio, along with the already mentioned selectio and combinatio. It consists of correcting the allegedly corrupted textual passages only by conjecture, for example by providing additions or by deleting and substituting some readings (see, among others, Avalle 1972a, 111-112; Luiselli Fadda 1994, 236-237; McDonald 1970, 1048-1050). However, Paul Maas, in his Textkritik (1927, 6-8), gives divinatio a broader meaning, which is very close to the notion of emendatio ope ingenii. Maas, in fact, uses this term to designate the third and final stage of textual restoration.

\section{Example 7: Cædmon's Hymn}

When choosing between variants which have equal stemmatic value (selectio), the editor may take into account a variety of potentially relevant factors, for example grammar, diction, metrical patterns in verse or rhythm in prose, stylistic features, and so on. It goes perhaps without saying that, since these precepts are not rules but rather statements of relative probability, they have to be used with caution as 
they have significant consequences for the text offered to the reader. The idea that the more difficult reading is also the preferable one seems to be logically robust (it encapsulates the assumption that scribes tend to simplify the text they are copying), but judging the difficulty of a reading can itself present challenges. The short Old English poem known as Cædmon's Hymn has come down to us in twenty-two Northumbrian and West Saxon witnesses, to which a Latin version should be added (Bede Historia ecclesiastica 4.22). Line 5b (O’Donnell 2005) of the Hymn contains a variant reading that identifies two recensions.
(a) hē ærist scōp
ylda/ælda b(e)arnum
(b) hē ærist scōp
eorðan/eordu/eorðe b(e)arnum

The first reading is that of the West Saxon ylda and Northumbrian ælda recensions, and would be translated "for the children of men": "He first created [the world] for the children of men". The West Saxon eorðan, Northumbrian eordu, and, with some corruption, West Saxon eorðe recensions would be translated "for the children of earth": "He first created [the world] for the children of earth". The indirect tradition (see 3.2) represented by the Latin text in Bede, Historia ecclesiastica 4.22, transmits the reading "filiis hominum", an image of biblical ascendancy and therefore preferred by many modern editors. Yet, as far back as 1946, Charles L. Wrenn interpreted "eorðan/eordu/eorðe b(e)arnum" as the lectio difficilior with respect to the later Christian formula "ylda/ælda b(e)arnum”. The choice between the two readings has consequences for the meaning of the text: while the latter places the text within the context of Christian orthodoxy, the former adds a more archaic note.

It should be noted that the principle of lectio difficilior, which is indeed applicable to high-register literary texts, may not apply to low-register ones where copyists, when faced with clumsy original readings, are likely to adapt them to their own more refined register. This is the case for some mediaeval Latin texts, such as the Itinerarium Antonini (see the discussion in P. Chiesa 2002, 89) or the Navigatio Sancti Brendani (Guglielmetti 2017), which were sometimes improved by more learned Carolingian or humanist scribes. For this reason, Paolo Chiesa (2002, 88) suggests thinking in terms of utrum in alterum abiturum erat, "the variant reading which is more likely to have passed into the other", by either corruption or improvement.

\section{Example 8: La Vie de Saint Alexis}

Connected with the notion of lectio difficilior is that of diffraction (see "1955-" in 2.4.3), also called multiple innovations. The latter was first explored theoretically by Gianfranco Contini in 1955, and further clarified by the same scholar in a speech given in 1967 (Contini 1986, 135-148). Contini draws the term from physics and applies it to the field of textual criticism, where it refers to the substitution of a particularly difficult, infrequent, or rare original reading with several innovative (but trivial) readings or attempts at clarification by the copyists. Contini then distinguishes 
the categories of diffraction in praesentia, where the reading that has caused diffraction is preserved in at least one witness, and diffraction in absentia, where the reading that has caused diffraction is lost. The following is an example of the second category, given by Contini himself $(1986,135-148)$ and taken from the tradition of the Old French La Vie de Saint Alexis (line 155; $L, A, P, P 2$, and $S$ are the manuscripts that transmit the diffracted readings). The previous line reads "Plainons ensemble le dol de nostre ami”.

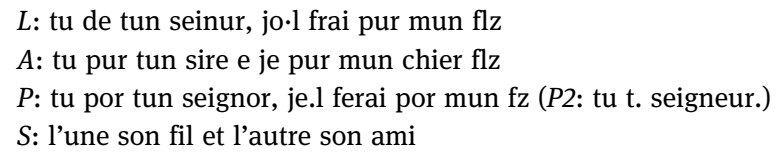

None of the readings of the extant manuscripts ( $L$ : "tun seinur", $A$ : "tun sire”, $P$ : "tun seignor", $S$ : “son fil”) are acceptable, for reasons of metre ( $L P P 2)$, morphology $(A)$, or meaning in context $(S)$. It has been argued by Adolf Tobler (1872), in his review of Gaston Paris's editio maior of Alexis, that the lost original reading could be an unattested one, namely "ton per" [your spouse]: "tu por ton per, jol ferai por mon fil". Using Contini's terminology, one can assume that the rare meaning of per, "spouse" (a morphologically masculine form), has generated diffraction leading to the different trivial readings attested in the witnesses: "seinur"/"seignor" [lord, husband] $(L / P)$, “sire”, nom. [lord, husband] $(A)$, "son fil” [his son] $(S)$.

\section{Example 9: Dante's Divina Commedia}

The opposite of lectio difficilior is lectio facilior, "the easier reading", a form of trivialisation. In the Divina Commedia, Inferno, canto 14, Petrocchi's reading "marturi” [inflict pain] for line 48 (= Petrocchi 1966-1967, 2:230) seems clearly a lectio facilior if compared to the traditional "maturi" [ripen] (see Bosco 1968, esp. 59; Paratore 1968); the former, in fact, obscures a striking metaphor which produces sarcasm characteristic of Dante:

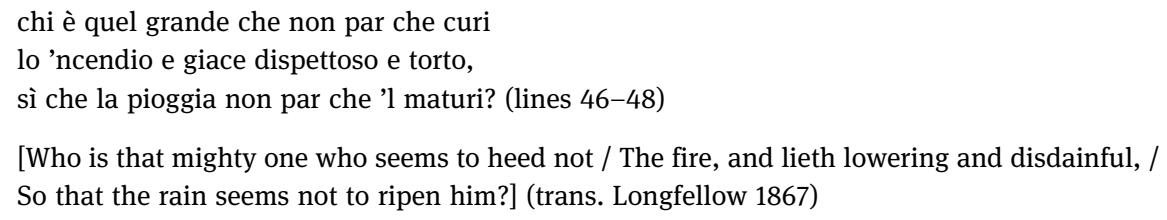

[Who is that mighty one who seems to heed not / The fire, and lieth lowering and disdainful, / So that the rain seems not to ripen him?] (trans. Longfellow 1867)

The verb marturi (vs maturi) would yield the easier reading "So that the rain seems not to torture him?", and therefore Petrocchi's choice seems, as some scholars have indeed argued, not to be the most appropriate in this context.

Another principle that can support the editor's judgement is that of lectio brevior (potior), according to which the shorter reading is the more probable one, on the grounds that the longer reading is more likely to be an attempt by copyists 
to clarify the meaning of the text (see 7.2.1). This notion seems to have been first used by Bengel $(1734,778)$ : "plerumque, si non semper, genuina est lectio brevior, verbosior interpolata" [often, if not always, the shorter reading is authentic, the longer is interpolated]. The application of this general statement to real textual tradition is more problematic than that of lectio difficilior.

\section{Example 10: Lucan's Bellum civile}

The notion of usus scribendi is based on the assumption that authors have their own stylistic preferences, that is, their own preferred modes of expression. Therefore, the reading which is closer to these modes is to be chosen by the editor. In book 1 of Lucan's Bellum civile, the first word of line 381 appears in two variants in two different branches of the manuscript tradition, namely "castra" $(\Omega)$ and "signa" $(Z)$. The former reading is usually preferred over the latter as it is thought to better reflect the usus scribendi of the Latin poet, who frequently uses the expression "castra ponere" in his works:

castra super Tusci si ponere Thybridis undas

Hesperios audax ueniam metator in agros. (lines 381-382 = Roche 2009, 78)

[If you bid me set up camp above the waters of the Tuscan Tiber / I shall come, a bold planner, into Hesperian fields.] (trans. Leigh 2016)

Although it is unquestionable that this principle has general validity, it should also be used with caution in editorial practice. In fact, uniformity of style cannot necessarily be ascribed to the original text: it can also result from a process of stylistic levelling carried out by copyists once they have become aware of the stylistic preference of the authors whose works they transcribe (some examples are discussed in Tarrant 2016, 58-59). Thus, there will be cases where usus scribendi and lectio difficilior may be in conflict with one another.

Sometimes, the archetypal reading can be reconstructed by combining two partially wrong variants (combinatio). D'Arco Silvio Avalle (1972a, 116) reports that in Peire Vidal's song “Atressi co.l perilhans” [I Am Like a Shipwrecked Man], line 26 reads “Tornari l'ir'en conort” in manuscript $C$ (Paris, Bibliothèque nationale de France, fr. 856) and "E tornara l'ir'en conort” in manuscript $R$ (Paris, Bibliothèque nationale de France, fr. 22543). In both manuscripts, the verb ending ( $C$ : “Tornar-i”, $R$ : "tornar-a") is morphologically wrong; the correct future form can be reconstructed by combining $R$ (“-a”) and $C$ (“-i”): “Tornarai l'ir'en conort” [I shall turn pain into joy] (see also Fraser 2006, 102). Furthermore, line 26 in $R$ begins with an extrametrical "E" [And], which is a clear anticipation of the conjunction in the following line, line 27: “E vivarai m'en alhors” [And I shall turn elsewhere]. On the basis of this metrical evaluation, the archetypal reading of line 26 is assumed to lack the conjunction.

An emendation is called ex fonte (emendatio ex fonte) when the correction of a plainly wrong quotation in the text is based on the reading transmitted by the 
source of the quotation. For example, in the laudatory poem for St Catherine, "Or mi conforta, bella”, contained in the Laudario di Modena, line 89 reads as follows: "cusí la te' a mostrare ch'eri sanctificata", while in the Legenda aurea one reads of her: "de eius corpore pro sanguine lac [= la(t)te, "milk"] emanauit" (Maggioni 2007, 1358). Therefore, line 89 should be emended accordingly as "ensî late a mostrare ch'eri sanctificata" [milk poured [from your body] to show that you were holy] (Del Popolo 2001, esp. 26).

When selectio is not enough to assess the readings that should be ascribed to the original, then divinatio may help. This is an extremely delicate operation, since the philologist relies only on conjecture. For this reason, it should be considered as a last-resort strategy and used with care. Nowadays, for example, editors tend not to emend heavily corrupted portions of texts, or extensive lacunae, since they are aware of the limits of this procedure. In critical editions, loci that are not emendable are usually marked with a crux desperationis $(\dagger)$. Even more so, grammatically acceptable readings should be treated with the highest care and emended with caution only when deemed absolutely necessary, in order not to produce erroneous conjectures, as exemplified in example 11 below. It is especially important to avoid anachronistic emendation that uses a form of language the author of the text may not have been familiar with.

\section{Example 11: The Battle of Brunanburh}

In his 1938 edition of a ninth-century Old English poem entitled the Battle of Brunanburh, Alistair Campbell found the readings of the witnesses for line 12b unsatisfactory, albeit grammatically correct: $A$ : "feld dæn 'n'ede" (the second $n$ being written above the line) - $B C$ : "feld dennade" $-D$ : "feld dennode" [the battlefield resounded [with the blood of the warriors]]. Therefore, he emended the line by divinatio into "feld dunnade" [the battlefield was darkened [with the blood of the warriors]] on the assumption that the verb "to get dark" was semantically more appropriate. By doing this, however, Campbell ruled out the possibility of synaesthesia, which not only is completely acceptable in the context (the battlefield resounded with the blows of the warriors' swords that brought many of them to their death) but would also make the poetic diction more precious (see O'Brien O'Keeffe 1990, 115; Buzzoni 2001, 79-81). Further examples of overconfidence on the part of editors can be found in Tarrant (2016, esp. 282).

In open traditions (see 4.4), where stemmatic analysis plays a more limited role, the editor's judgement becomes much more important. In such traditions, the distinction between older manuscripts (codices vetustiores) and more recent ones (codices recentiores) can be so blurred as to be almost useless in discriminating between or among variants. Codices vetustiores are traditionally held to transmit better readings than the more corrupted recentiores, but this is clearly an overgeneralisation. As Pasquali (1952, 41-108) suggested, later witnesses are not necessarily inferior recentiores non deteriores (see 2.2.4, 2.4 above) - since they may transmit 
lectiones vetustiores for which no older witness happens to survive. This may also apply to extremely late witnesses such as editiones principes (i.e. the first printed editions of a work; see 1.4): an excellent example is offered by the editio princeps of Jacopone da Todi's Laudi published in Florence in 1490 and based on manuscripts which were subsequently lost, thus transmitting a series of lectiones vetustiores despite its late date (Brambilla Ageno 1975, 18). With the exception of perspicuous instances, deciding when to accept a reading found in later witnesses is one of the most difficult choices an editor has to make.

\title{
6.2.3.1 Codices unici
}

Along with open traditions, another peculiar situation is represented by codices unici (singular: codex unicus; see 1.2.3), where judgement alone can be used to restore the text since the editor cannot rely on a stemma to choose between variants. Despite this, an interpretative critical process can be carried out: even in the absence of points of comparison, the editor should proceed from what is attested and known (the historical single witness) to what is unattested and therefore unknown (the original) following the emendation steps illustrated here. Many noteworthy Italian literary monuments are transmitted in single manuscripts, among them the anonymous Il fiore and Il detto d'amore, cleverly edited by Gianfranco Contini (1984) in a methodologically highly influential volume. Similarly, the majority of early Germanic texts are transmitted in single manuscripts. In these cases, in order to avoid the overuse of conjectural emendations, a thorough study of the unique witness and its transmission has to be performed (see, among others, Avalle 1972a, 25-27; Brambilla Ageno 1975, 26-37; Luiselli Fadda 1994, 190-191, 224-225; Stussi 2006, 19; on the potential offered by the digital environment, see Bleier et al. 2018).

\section{Example 12: Beowulf}

Line 2298 (= Fulk, Bjork, and Niles 2008, 79) of the Old English poem Beowulf reads as follows:

\author{
on $\mathrm{p}(\mathrm{am})$ westenne hwæðre wiges gefeh. \\ [in that wilderness, however [he] looked forward to the battle.]
}

The unique manuscript which transmits the text (London, British Library, Cotton Vitellius A.xv) has the reading "hilde" instead of "wiges". The latter, included in the text by conjecture, is preferred by many editors (since Klaeber's 1922 edition) for metrical reasons: "wiges" in fact alliterates with "westenne" in 2298a, both beginning with the labio-velar semi-vowel [w].

\subsubsection{Dispositio}

Once critically established, the text has to be offered to the reader (see 6.3). The term dispositio refers to the final stage of editorial work, in which the critically es- 
tablished text is positioned on the page, together with the critical apparatus that records the evidence on which the text established by the editor rests. This is the main reason why the apparatus does not simply complement the edition; it is rather the result of editorial judgement and thus it is as essential to the critical edition as the text itself.

The various formats that an a parat us can assume (in compliance with more minimalist or more maximalist approaches to it; see Tarrant 2016, 130), as well as the selection of information to be included, will be discussed in detail in section 6.3. Here, it will suffice to note that the main purpose of a critical apparatus is to account for the choices made by the editor by recording the pertinent textual evidence. Furthermore, by making the editor's acts of judgement visible, the critical apparatus allows the reader to either confirm or reject the readings accepted by the editor. The apparatus is therefore the core of the critical process, and perhaps even more. Back in 1974, Cesare Segre argued that the apparatus should be the location where the tension between respect for the antigraph and the innovative thrust of the copyist is brought to the fore:

Occorre [...] capovolgere i rapporti gerarchici fra testo e apparato, dare la maggiore enfasi all'apparato e considerare il testo come una superficie neutra [...] su cui il filologo ha innestato le lezioni da lui considerate sicure, fra le tante considerate. Ma l'edizione si merita l'attributo di critica molto di più attraverso l'apparato, se discorsivamente problematico: perché esso sintetizza il diasistema della tradizione, e perché svolge un vaglio completo, anche se non sempre conclusivo, delle lezioni. (Segre 1978, 497)

[There needs to be a turnaround [...] in the hierarchical relationships between the text and the apparatus, in order to give greater emphasis to the apparatus and consider the text as a neutral surface [...] onto which the philologist has grafted the readings which he deemed certain among the many considered. However, an edition deserves the attribute of being "critical" much more through the apparatus that ought to disclose a critical discourse: because it summarises the diasystem of the tradition, and because it carries out a full assessment of the readings, even if it is not always conclusive.]

It is precisely in the apparatus that the text emerges as a diasystem (see 2.4 above), a term first applied to textual criticism by Cesare Segre (1976) to express the idea that the text transmitted in a given manuscript represents the contact between the linguistic system of the author and those of the copyists who filter the exemplar through their own codes.

Usually, in print editions, the reconstructed text is placed on the upper part of the page, followed by two (or more) apparatus areas: an apparatus fontium et locorum parallelorum and a critical apparatus in the proper sense (either in its negative or positive version; see 6.3.2.2). An illustration of what a critical edition can look like is provided in figure 6.2-11, where the critically restored text of the Heliand is complemented by the critical apparatus as well as an apparatus fontium.

If different versions of the same work have been postulated by the editor, their texts are usually given in parallel columns, thus providing a synoptic edition (see 6.1). 
endi mid hluttron treunon. Uuarth thuo thie helago gest, that barn on iru buosme; endi siu an iro brioston farstuod iac an iro sebon selbo, sagda them siu uuelda that sea habda giocana thes alouualden craft

295 helag fan himila. Thuo uuarth hugi Iosepes, is muod giuuorrid, thie im er thia magat habda thia idis andhetia, ađalcnuosles uuib giboht im ti brudi: hie afsuof that $\left(12^{\mathrm{b}}\right)$ that siu hatda barn under iru:

ni uuanda thes mid uuihti [neua] that iru that uuib habdi 300 giuuardot so uuarlico: ni uuisse hie uualdandes thuo noh blithi gibodscipi. Ni uualda sia im te bradi thuo halon im ti hiuuon, ac began im thuo an is hugie thenkean huo hie sia thuo* farlieti, so iru thar ni uurđi lethes uuiht odan arbedies. Ne uuelda sia after thiu

305 meldon for menigi: andried that sea manno barn libu binamin. So uuas than thero liudeo thau thuru then aldon eu, Ebreo folces, so huilik so thar an unreht idis gihiuuada, that siu simla thena bedscepi buggean scolda

310 fri mid iru ferahu. $\mathrm{Ni}$ unas gio thiu fehmea so guod that siu gio mid them liudion leng libbean muosti, uuesan under them uuerode. Thuo bigan im the uuiso man, suitho guod gumo Ioseph an is muode thenkean thero thingo, huo hie thea thiornun tho

315 listion forlieti. Thuo ni unas lang ti thiu that im thar an drome quam drohtines engil, hebancuninges bodo, $\left(13^{*}\right)$ endi hiet sia ina haldan unel, minneon sia an is muode: ' $\mathrm{Ni}$ unis thu' quathie, 'Mariun uureth, thiornun thinero - siu is githungan uuib $320 \mathrm{ni}$ forhugi thu sia ti hardo; thu scalt sea haldan uuel,

91 brioston | stuod 300 gin ${ }^{\mathrm{u}}$ ardot $11 \mathrm{~m}^{\mathrm{u}}$ osti corr. $2, h .20 \mathrm{ti}^{\mathrm{b}}$ ardo

91-92. Tat. V. Mt. 1, $18 \ldots$ inventa est in utero habens de spiritu sancto. $95-305$. Mt. 1, 19 . Joseph autem vir eius, cum esset iustus et nollet eam tradere, voluit oceulte dimittere eam. 12-25. Mt. 1, 20. Haec autem eo cogitante, ecce angelus domini apparuit ei

Fig. 6.2-11: Critically established text and apparatuses. Source: Sievers (1878, 24).

In this edition of the Heliand (Sievers 1878), the texts of the two major witnesses, $C$ and $M$, are provided on facing pages as shown in figure 6.2-12.

A richer, multilayered apparatus is offered by Francesco Stella (2007) in his digital edition (see 6.4 below) of the Latin Corpus rhythmorum musicum saec. IV-IX (see fig. 6.2-13). This type of apparatus accommodates intertextual information such 

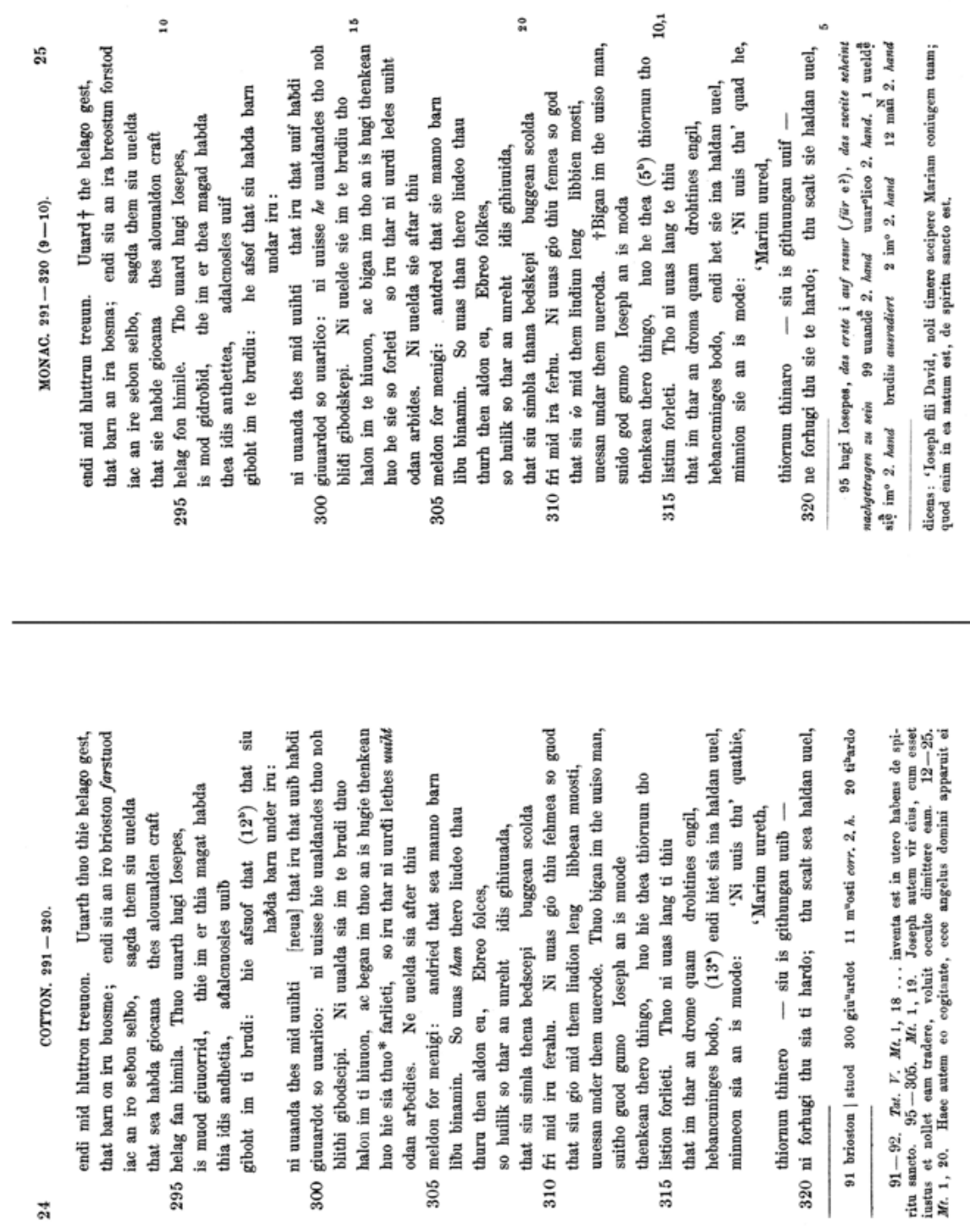

Fig. 6.2-12: Synoptic edition. Source: Sievers (1878, 24-25). 


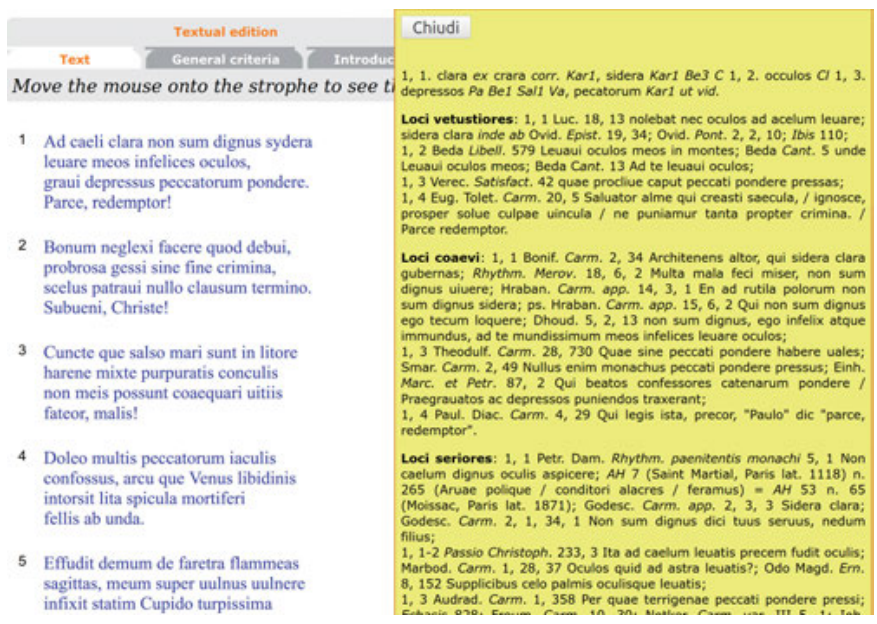

Fig. 6.2-13: Multilayered apparatus fontium along with lectio variorum (corimu.unisi.it).

as sources and antecedents (loci vetustiores), contemporary parallels (loci coaevi), and alleged later reuses (loci seriores), along with the variant readings found in the tradition of the rhythmi (lectio variorum) given in the upper right-hand part of the screen. It should be noted that, despite the digital environment, the construction of the apparatus follows the steps illustrated in the previous sections, and is therefore based on a thorough scrutiny of the manuscript tradition of every single poem.

An experimental kind of critical apparatus has been drafted by Burgio, Buzzoni, and Ghersetti (2015) in their hypertext edition of Giovanni Battista Ramusio's sixteenth-century version of Marco Polo's account of his travels in Asia. In this "Digital Ramusio", modal windows allow the user to visualise a chapter of the main text $(R)$ in parallel with its major sources $(Z, V, V B, L, P$ and $V A$, and $F)$. Each chapter of $R$ is accompanied by a philological commentary made accessible through pop-up windows and containing the identified sources along with their variant readings against $R$, analysis of their manipulation by Ramusio, as well as some informative notes. This more discursive apparatus (fig. 6.2-14) aims to filter the data provided by the editors after a thorough critical process by providing a narrative that explains and make sense of it (for the theoretical approach, see Lavagnino 2009, 63-76).

The layout of editions, as well as some other practical details, have changed over time. The format which is now standard for a critical print edition, with the apparatus of variants being placed below the text, is the result of a long development. It originated in the course of the eighteenth century from "earlier modes of presentation in which information about manuscript readings was usually embedded within a larger commentary surrounding the text on three or four sides" (Tarrant 2016, 125), a practice that can be traced back to thirteenth-century manuscripts transmitting texts along with their commentaries. 


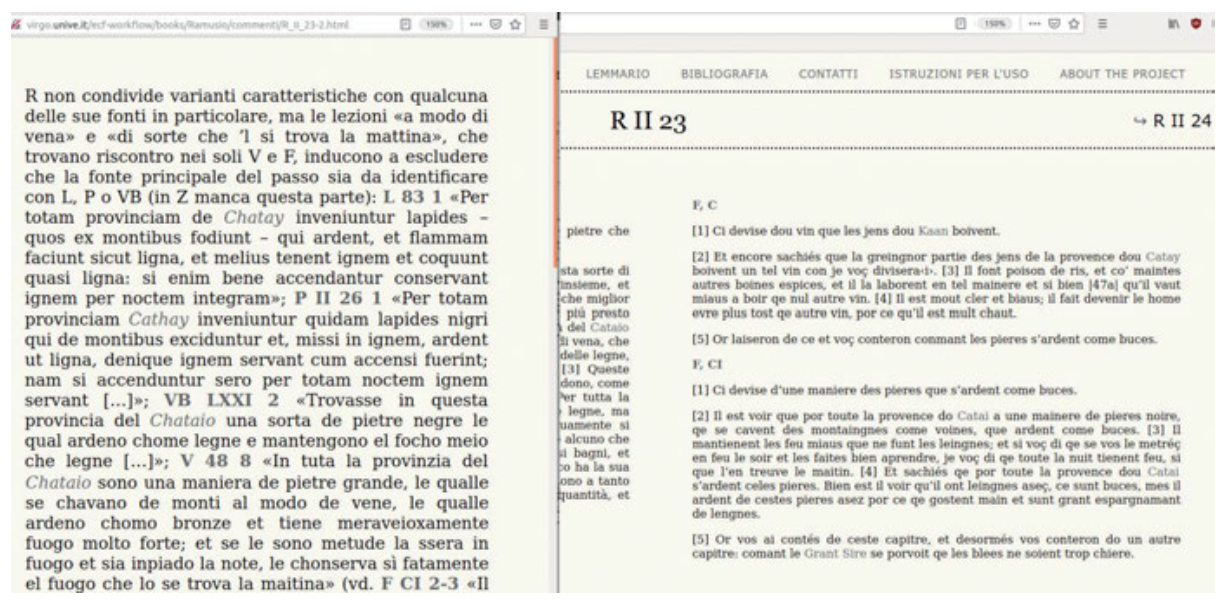

Fig. 6.2-14: A discursive scholarly apparatus.

Source: virgo.unive.it/ecf-workflow/books/Ramusio/commenti/R_II_23-main.html.

The habit of using sig la to denote manuscripts also developed over a long period of time. Only in the nineteenth century did it establish itself as a common procedure, superseding - though not completely eliminating - that of referring to manuscripts by Latin names, such as Codex Monacensis $(=M)$ or Codex Cottonianus $(=C)$ in the case of the Heliand.

\subsubsection{Recent developments}

Although the general principles of text-critical analysis discussed in the present section remain substantially valid today, new perspectives have arisen from the growing awareness that, especially in traditions that are likely to be highly unstable - such as many mediaeval ones - genealogical trees very rarely show a linear structure, and in some cases multiply rooted trees are perhaps more apt for representing the relationships between given groups of witnesses (see 2.2 above and example 13 below).

Furthermore, it is also possible that, in order to establish the older form of a reading, a philologist has to take into account textual traditions that are very different typologically, and sometimes also linguistically (see example 14), thus crossing the borders between texts.

\section{Example 13: Wulfstan's Sermo Lupi ad Anglos}

Contemporary scholars are becoming increasingly aware that the lack of significant errors in one or more witnesses, a very frequent case in real traditions, leaves a large number of trees possible. A paradigmatic example is represented by Wulf- 


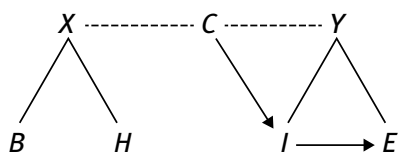

Fig. 6.2-15: Hypothesis of stemmatic configuration for the three different redactions of Wulfstan's Sermo Lupi ad Anglos (drawn on the basis of Bethurum 1971 and Whitelock 1980).

stan's Sermo Lupi ad Anglos quando Dani maxime persecute sunt eos, whose original composition is commonly assumed to go back to the year 1014 (Bethurum 1971, 2224; Whitelock 1980). The text is transmitted in five manuscripts - usually labelled as $I, E, C, B, H$ - and the lack of conjunctive errors between them blocks the reconstruction of a common archetype. There seem instead to be three different redactions of the Sermo, all of them traceable to Wulfstan himself, since his own interventions are visible in the witnesses: $(B H) C(I E)$. The shortest redaction $(B H)$ is usually taken to be the oldest (as shown, inter alia, by a clause referring to Æthelred's exile that is missing in $C, I$, and $E$ ); the $C$-text is a rewriting with deletion of political passages and incorporation of some additions, among which are the description of the Danish humiliations of the English in lines 97-126 in Bethurum's edition; $I E$ is the most recent redaction, very close to $C$ but with further interventions by the author himself, as the marginal additions in $I$ demonstrate (Bethurum 1971, 23; Whitelock 1980, 5-6). The situation is made even more complex by intrastemmatic contamination, as shown in figure 6.2-15. We are therefore confronted by at least three different forms of the sermon resulting from a process of rewriting primarily induced by a change in the political climate; in a stemmatic context, rewriting can produce multiply rooted trees like the one in figure 6.2-15.

The stemma tells us that the copyist of $I$ had not only $Y$, but also $C$ (or an ancestor of $C$ ) as a model, as demonstrated by a passage taken from $C$ at line 85 in Bethurum's edition and later on expunged from the text ( $I$ was corrected by Wulfstan himself); furthermore, $E$ used $I$ as a source, since some of the corrections and authorial interventions in $I$ are integrated into the text of $E$.

\section{Example 14: Ecdotic stratigraphy}

A further example of how intricate the relationship between texts can be is offered by Gianfranco Contini (quoted in Stussi 2006, 111), who performs a stratigraphic examination of a reading which appears in three different variant forms in the textual tradition of La Vie de Saint Alexis, namely “plorent si oil”, "ploret de ses oilz”, “ploret des oilz” [to cry the eyes out, to cry bitterly]. A comparison with the same variant forms as they occur in different textual traditions, in particular in the Old French Chanson de Roland and the Old Spanish Cantar de mio Cid allows Contini to postulate "plorent si oil" as the older form (attested only in Alexis), "ploret de ses oilz" as the intermediate form (attested in all three traditions), and "ploret des oilz" as the most recent one (widely 
attested in Roland and only rarely in Alexis). Contini interprets such an example as an instance of stratigrafia ecdotica, "ecdotic stratigraphy", since from a reconstructive perspective it allows one to assess the older form of the reading.

The examples provided in this section are intended to provide some insight into how to practically handle textual data in order to figure out the most convincing stemmatic hypothesis among a set of theoretically possible stemmata, as well as how to determine the readings most likely to be original or archetypal. Although the application of the reconstructive method implies that the text to be restored is substantially unitary (reductio ad unum), a thorough scrutiny of real textual traditions shows that cases of texts that "live in variants", in that they are reshaped, for instance, by the authors themselves (see example 13 above) or by copyists who act as co-authors and editors, are not infrequent. Real case studies also help demonstrate that stemmata - as accurate as they may be - still remain working hypotheses, since they are based on the often partial data that has come down to us through the accidents of textual transmission. Given the evidence available, the goal of reconstructing the "original" version of a text is hardly ever achieved. As convincingly argued by Richard Tarrant, "one hallmark of the heroic mode of editing was the drive towards certainty, or even the confident assertion of certainty. Our time is one that finds such claims suspect” $(2016,29)$.

A further reflection induced by the treatment of real examples is that an approach which draws on multiple witnesses and tries to reconstruct a text that is identical to none of them does not undermine the importance of each single witness, provided that the editor offers the reader an apparatus where the diasystem of the tradition is summarised, as envisaged by Cesare Segre (see 6.2.4 above).

\subsection{Representing the critical text}

Franz Fischer

Every scholarly edition has to be understood as an embodied argument about the textual transmission. (Eggert 2009, 177; quoted in Tarrant 2016, 124)

This section deals with the components and presentational features of critical texts which are essential to both print and digital editions. Standards and conventions for presenting the critical text in print have been developed over the past two centuries - and, as will be demonstrated in the following, are fundamentally challenged by the digital paradigm.

\subsubsection{General considerations}

The appearance of the critical text in print has not significantly changed since the publication of the first handbooks for the establishment of a critical text a century 
ago (for an account of the consolidation of the print format from a technological perspective, see Sahle's volume on the typographical legacy: Sahle 2013, vol. 1, here esp. 111-112). In 1909, detailed guidelines for the composition of critical editions were published by the German classicist Otto Stählin. Largely revised in 1914, these guidelines provide clear instructions regarding the content and design of the edition, from title page and preface, to text and margins, to apparatus and indexes (Stählin 1914, 45-108). In 1927, then, most influentially, Paul Maas proposed a small set of rules for the preparation of a critical edition (Maas 1927, §23-24). First, a preface to the critical text should describe all witnesses, demonstrate the relationship between the witnesses (if possible with a stemma), and characterise the quality of the archetype; the handling of questions of orthography and (since Maas's revised edition of 1950) dialect, that is, linguistic regularisation, should be clarified. Second, in the critical text itself, all conjectures, supplements, and corruptions should be marked using special signs. Editorial interventions for reader-friendliness and elucidation such as word separation, punctuation, and capitalisation are desirable, but cannot be standardised in a set of rules of general applicability because the aims of interpretation change with changing times. Third, in a critical apparat u s underneath the text, some deviations from the archetype should be noted: rejected variants (according to Maas, "variants" in this sense are only those readings where the top branches below the archetype differ and between which the editor has to use iudicium). Subvariants and groups of variants from lower down in the stemma may or may not be indicated; the same goes for uncertainties, changes of witness, and brief justifications of editorial decisions.

Subsequently, such manuals have been further refined and modified, especially with regard to mediaeval and vernacular texts in response to the criticisms of Bédier and, later, the proponents of a New Philology (see 2.3). Conseils pour l'édition des textes médiévaux by Pascale Bourgain and Françoise Vielliard (2002) is a more recent example of a highly instructive comprehensive guide on how to establish and lay out the critical text of a mediaeval Latin or vernacular work. The guide takes into account the different national traditions and practices regarding aspects of original and normalised orthography, abbreviations and punctuation, the selection and presentation of variants and sources in the respective apparatuses, and so on. However, the basic components and the general composition of a print edition remain stable and unchanged.

Influenced by the new technical possibilities and the prospect of unlimited space, Peter Robinson widened the aims of a critical edition in a digital format and at the same time loosened the requirement of providing an edited text. According to Robinson (2002, 51-54), a digital critical edition should (still) be anchored in a historical analysis of the material, present hypotheses about creation and change, and supply a record and classification of difference over time, in many dimensions and in appropriate detail. The final product of a single established critical text is not deemed necessary any more, even if Robinson concedes that, in most cases, a single 
text constructed by the editor is included among all the texts presented, such as transcripts and collations, as a starting point for explaining all the extant documents (Robinson 2002, 55-56; 2000, 5-14). But, more importantly, the edition should provide the space and tools for readers to develop their own hypotheses and ways of reading. And all this should be offered in a manner which enriches reading (Robinson 2002, 56-58).

In the light of the recent developments, extending the narrow definition of a critical edition - used in this handbook only if genealogical considerations in the sense of a traditional recensio are applied - the term "critical edition" may be understood in a wider sense in which it "refers to a whole spectrum of editions of texts, documents, and collections that offer well-defined and structured information relating to a clearly identified content” (Apollon and Bélisle 2014, 86). According to Daniel Apollon and Claire Bélisle, critical editions intend to make a record of the textual transmission "as faithfully, authentically, and completely as possible, including information about the processes that have made it possible to establish the selected and published text" $(2014,86)$. These intentions are combined with "efforts to establish (or restore) the possibility of interpreting a work as closely as possible to the intentions of the author (traditional version), to its immediate context (historicising version), or to its uses during the transmission through time and space" (86).

In more specific terms, Fischer (2017, 278-280) assembled various components of digital critical editions with reference to four basic manifestations of textual criticism. The first manifestation is critical annotation, that is, indispensably, the apparatus criticus or other means of recording textual variants and all justifications for the state of the edited text (established on the basis of various methods; see Göransson 2016, 407-415), but also an apparatus fontium or testimoniorum, an apparatus biblicus, and/or a commentary (see Giannouli 2015; more on these types of apparatuses below). The second manifestation is structural, linguistic and semantic markup - that is, the actual encoding of all textual and editorial components (see below). The third manifestation comprises all metadata, that is, all structured information on the author, the work, and the edition itself. Documentation, finally, comprises everything traditionally provided in the philological introduction (i.e. descriptions of the textual witnesses, a genealogical analysis, and a declaration of the editorial principles) but also, in a digital setting, facsimiles, transcriptions, source code, and raw data.

\subsubsection{Print editions}

\subsubsection{The critical text}

As described in the previous section (6.2.4), the disposition of the critical text on the page is a constituent part of the establishment of the text itself. In fact, critical editions are among the finest products of scholarly print culture. Both methodology and technology were decisive factors in the development of the sophisticated refer- 
ence system linking the actual text and the critical annotation (Dahlström 2000; Sahle 2013, 1:272-275). The print format, with its preference for the one synthesised and definitive text, has undeniably been a factor in the success of the stemmatological method and promoted the idea of a reconstructed archetype over alternative, individualistic and pluralistic, textual concepts (see 6.1). Stemmatology is able to provide the methodological justification for a single text representation instead of multiple texts or any arbitrarily chosen individual copy. In addition, other justifications can also be taken into account, such as reader-friendliness and the convenience of a scholarly practice of reading and referring to one text only instead of many.

Even if divergent traditions are deemed equivalent with regard to their origin as authorial revisions (e.g. due to enforced or even self-imposed censorship) or to their impact on a subsequent readership, parallel views of two, sometimes three, and in very few cases even four versions remain the exception. A widely acclaimed edition of the Nibelungenklage pushed the print format to its limits and presented four critical text versions with four respective apparatus critici positioned on two facing pages (Bumke 1999). Even here, variation within a distinct tradition was condensed and represented in respective apparatus critici (fig. 6.3-1). Another exception is the monumental edition of Eriugena's Periphyseon in five volumes by Edouard Jeauneau (1996-2003), which establishes not only a critical text "of common type, easy to read and consult” (1:lxxxi), but also a synopsis of five variant versions as revised by the Irish author himself or contemporary scribes, displayed in four parallel columns (figs 6.3-2-3). 


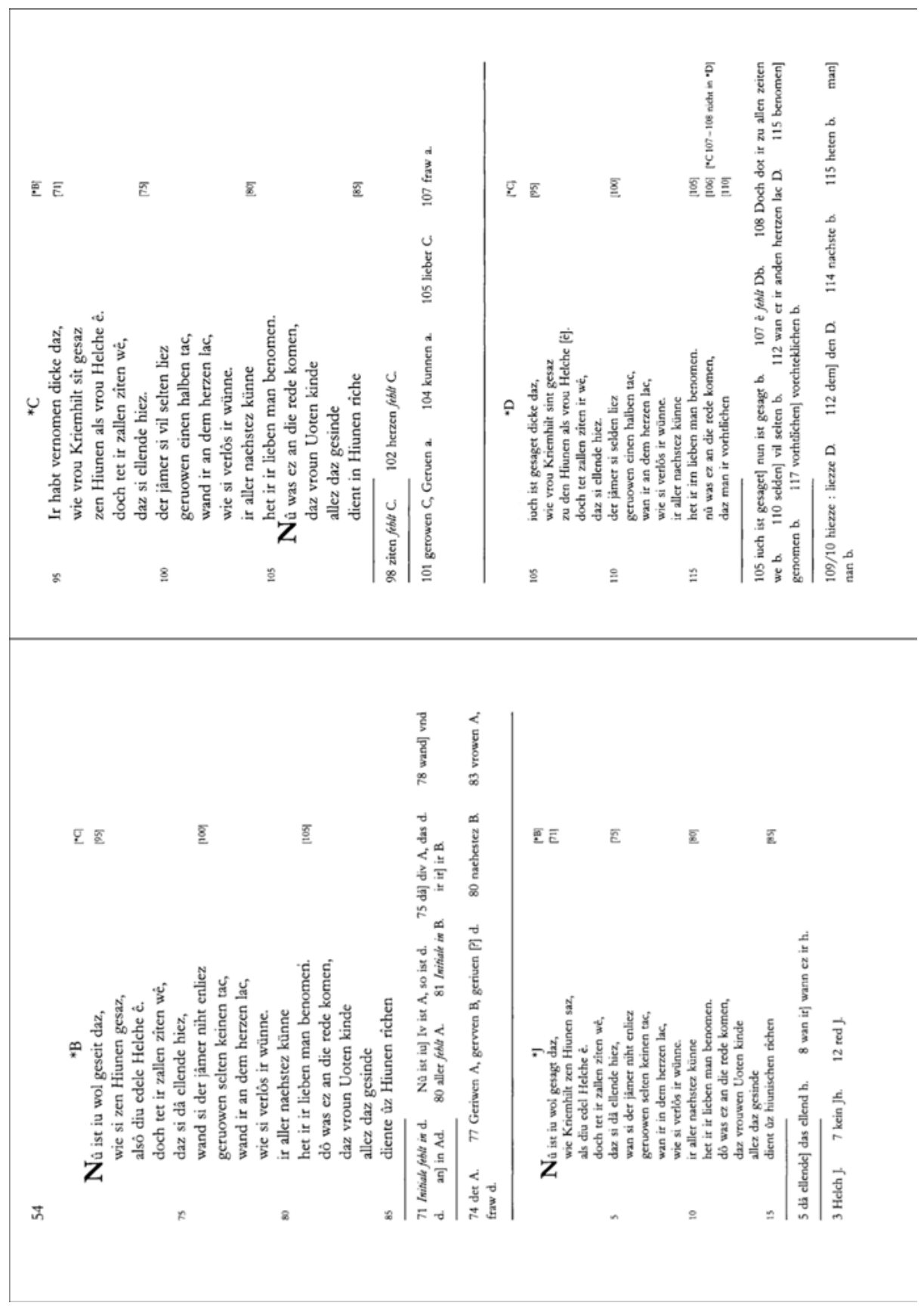

Fig. 6.3-1: Joachim Bumke's synoptic print edition of four versions of the Nibelungenklage. 


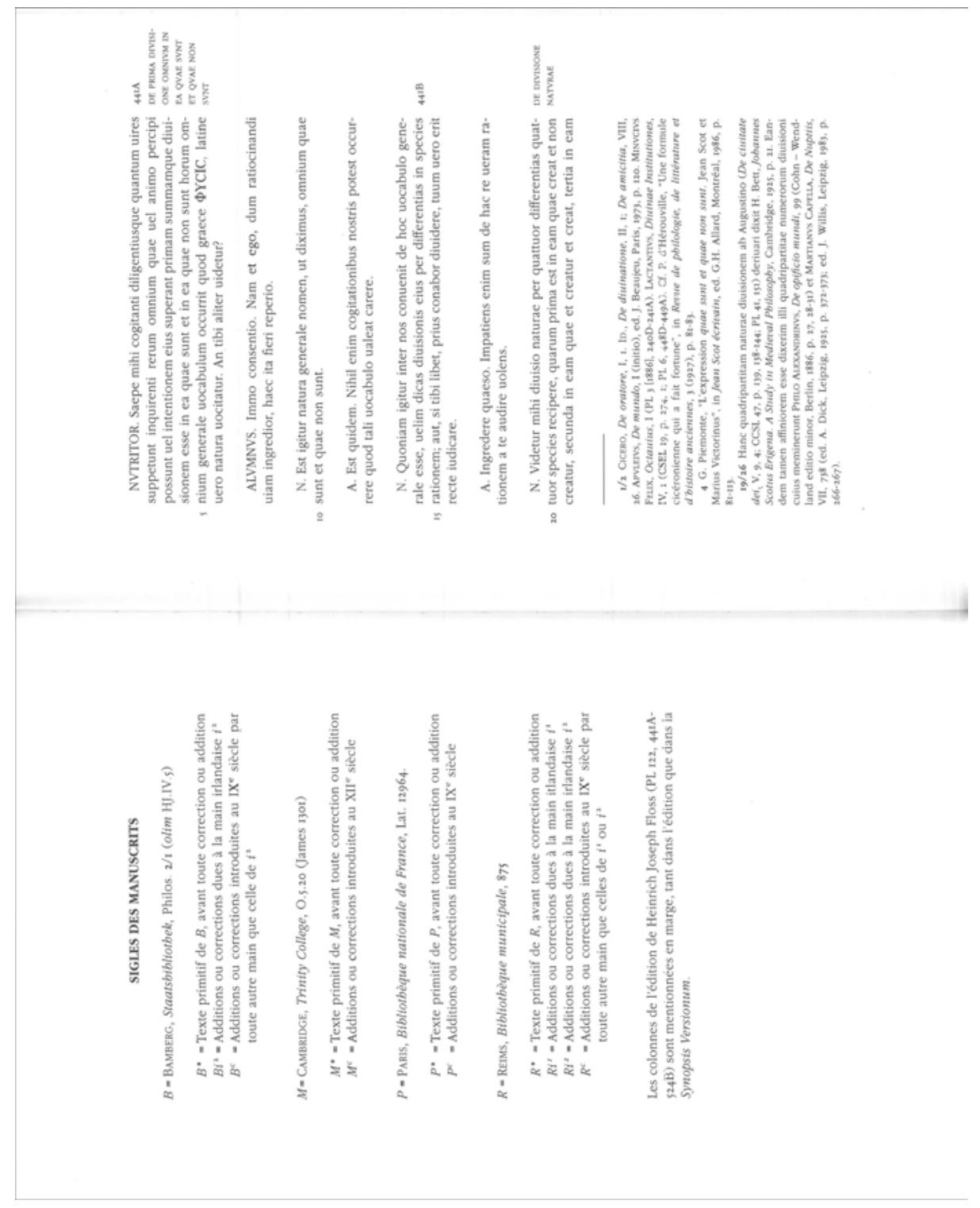

Fig. 6.3-2: An extract from the critical text of the first book of Eriugena's Periphyseon with apparatus fontium below and index siglorum on the left-hand page, edited by Edouard Jeauneau (1996-2003, 1:2-3). () Brepols Publishers. 


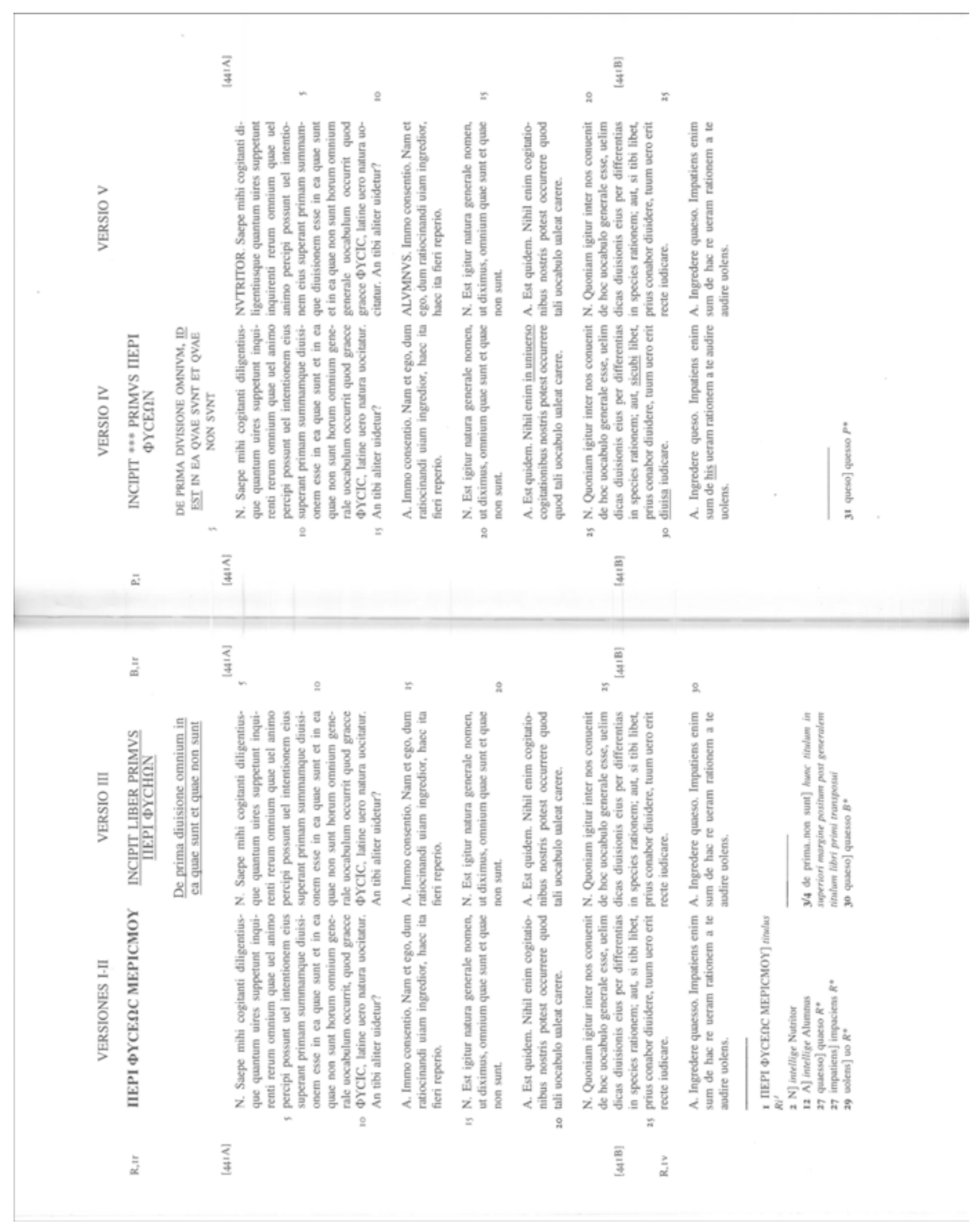

Fig. 6.3-3: Synopsis of the same book in five different versions presented in four columns with respective apparatus critici in the same edition. Source: Jeauneau (1996-2003, 1:114-115). (c) Brepols Publishers. 


\subsubsection{The critical apparatus}

The design of the apparatus criticus is inherited from the print era. Maas already noted: "Daß der kritische Apparat unter den Text gesetzt wird, geschieht aus Rücksicht auf die Verhältnisse des Buchdruckes, besonders auf das Format unserer Bücher" $(1960,16)$ [The apparatus criticus is placed underneath the text simply on account of bookprinting conditions and in particular of the format of modern books] (trans. Flower, 1958, 23). The term itself, apparatus criticus, "may have been used for the first time in Bengel's book title D. Io. Alberti Bengelii Apparatus criticus ad Novum Testamentum, Tubingae 1763" (Conti and Roelli 2015; see also Timpanaro 1981, 35; $2005,65)$. There, the elaborate apparatus was provided in a book printed separately from the edited text. Lachmann's edition of Lucretius' De rerum natura libri sex from 1850 presented a limited number of genealogically significant variants without further identification under the reconstructed text (fig. 6.3-4); a detailed philological explanation was provided in his commentary published in a separate volume.

The apparatus was to become the most distinctive feature of a critical text. Its aim is to ensure the reversibility and transparency of the editorial decisions. It pro-

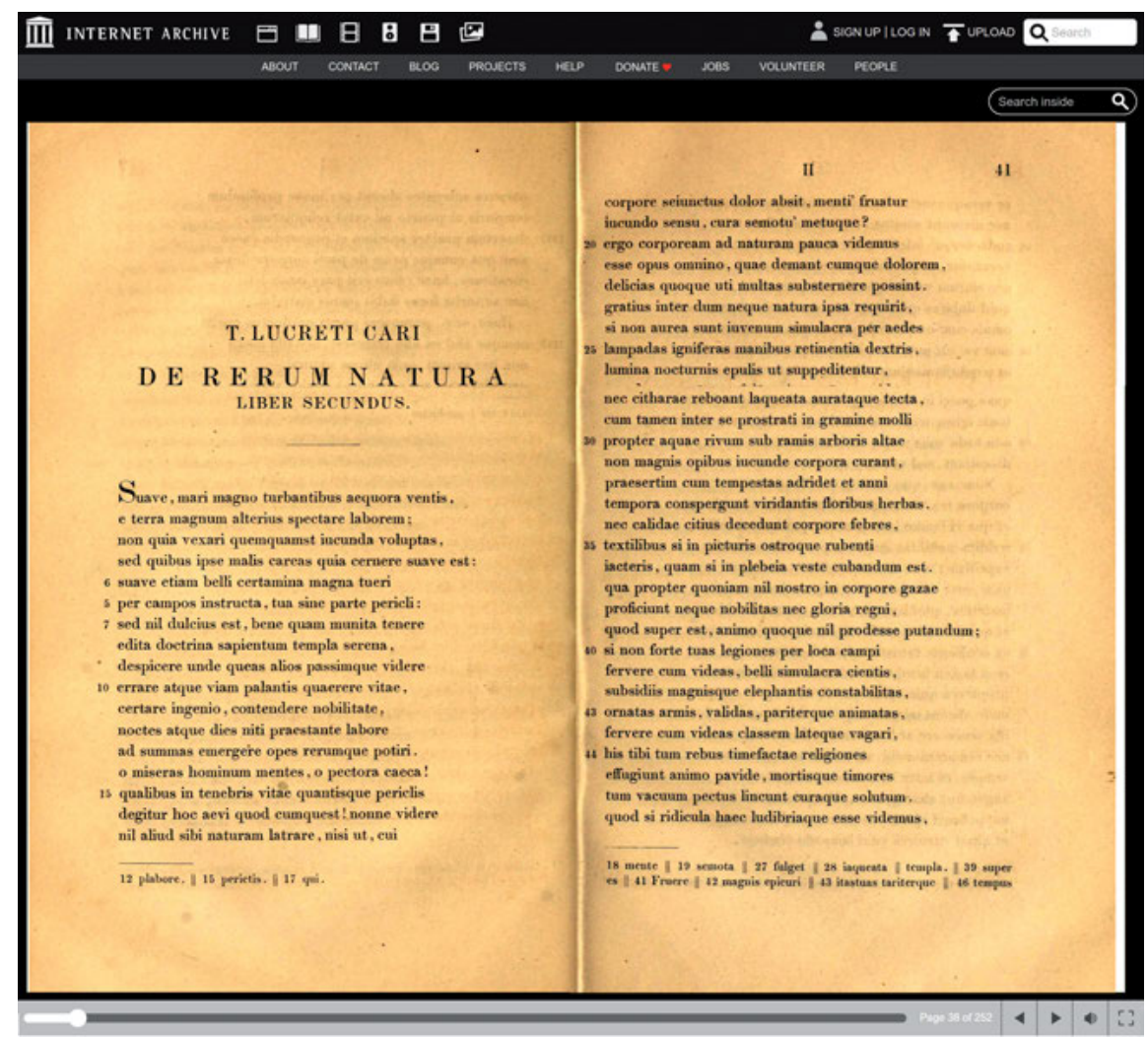

Fig. 6.3-4: PDF facsimile of Karl Lachmann's 1850 edition of Lucretius' De rerum natura from the Internet Archive (archive.org/details/dererumnaturalioolucr). 
vides the evidentiary justification for the presentation of a specific text and allows the reader to test the hypothesis of the edited text. The reader should be able to follow the logic of the presentation of the text (and the selection of readings) and (re)trace the editor's work using the critical apparatus (P. Chiesa 2016, 228-236). A manifestation of textual criticism, the apparatus provides the mark of a scientific, scholarly, reliable, and authoritative text. It makes the text distinct from ordinary texts, randomly published or passed on. The apparatus distinguishes an edition that is critical (in the sense that it analyses data and presents a hypothesis) as opposed to those not based on scientific principles.

The critical apparatus is usually accompanied by an apparatus fontium, indicating the sources for passages in the edited text. References to similar passages in other works that have not been used as a source can either be included in the same apparatus, or they can be recorded in a dedicated apparatus locorum parallelorum. Relevant especially for theological and patristic texts, an apparatus biblicus may give references to biblical passages quoted or alluded to, while an apparatus testimoniorum may indicate the use of passages in later works. As proper complements to the critical apparatus, these various types of apparatuses should provide the essential justification for the established text and help to better understand and appreciate its composition technique and literary impact (Giannouli 2015). More extensive annotations such as historical, philological, and other commentaries are usually provided in separate sections of the book or accompanying publications.

In general, two types of critical apparatuses can be distinguished: a p os itive a p p r at u s indicates both those witnesses bearing variant readings that have been rejected and those witnesses attesting the reading accepted for the critical text; a negative apparatus indicates only witnesses of discarded readings. For example, where the text below (fig. 6.3-5) reads "contemtibilissimus", the negative apparatus entry appears as " 3 contemptibilissimus: contemptibilis sum D". A positive apparatus entry for the same scenario would appear as "3 contemptibilissimus $\Phi$ (=PVRFCG): contemptibilis sum D". The advantage of the positive apparatus is that it is explicit, which is especially helpful if the availability of witnesses is inconsistent, but it can get overcrowded and obstruct the reader's view of significant variation. For this, a middle path is often chosen: giving the full record of a positive apparatus only in those situations that seem to require more clarification.

Some conventional features and signs of a fully-fledged print edition are presented below using the example of Ludwig Bieler's edition of St Patrick's Confessio (fig. 6.3-5). References to individual manuscript witnesses are usually given by capital Latin letters $(A, B, C, \ldots)$, references to early prints by minuscule Latin letters $(d$, $e, f, \ldots)$, and references to manuscript families by Greek capital letters $(\Delta, \Phi, \Psi, \ldots)$. Revisions in a witness by a second hand might be indicated with an apostrophe after the siglum $\left(A^{\prime}\right)$. Other typical editorial signs include angle brackets $(<\ldots>)$ for editorial insertions of text missing in the archetype (or, when a genealogical method 

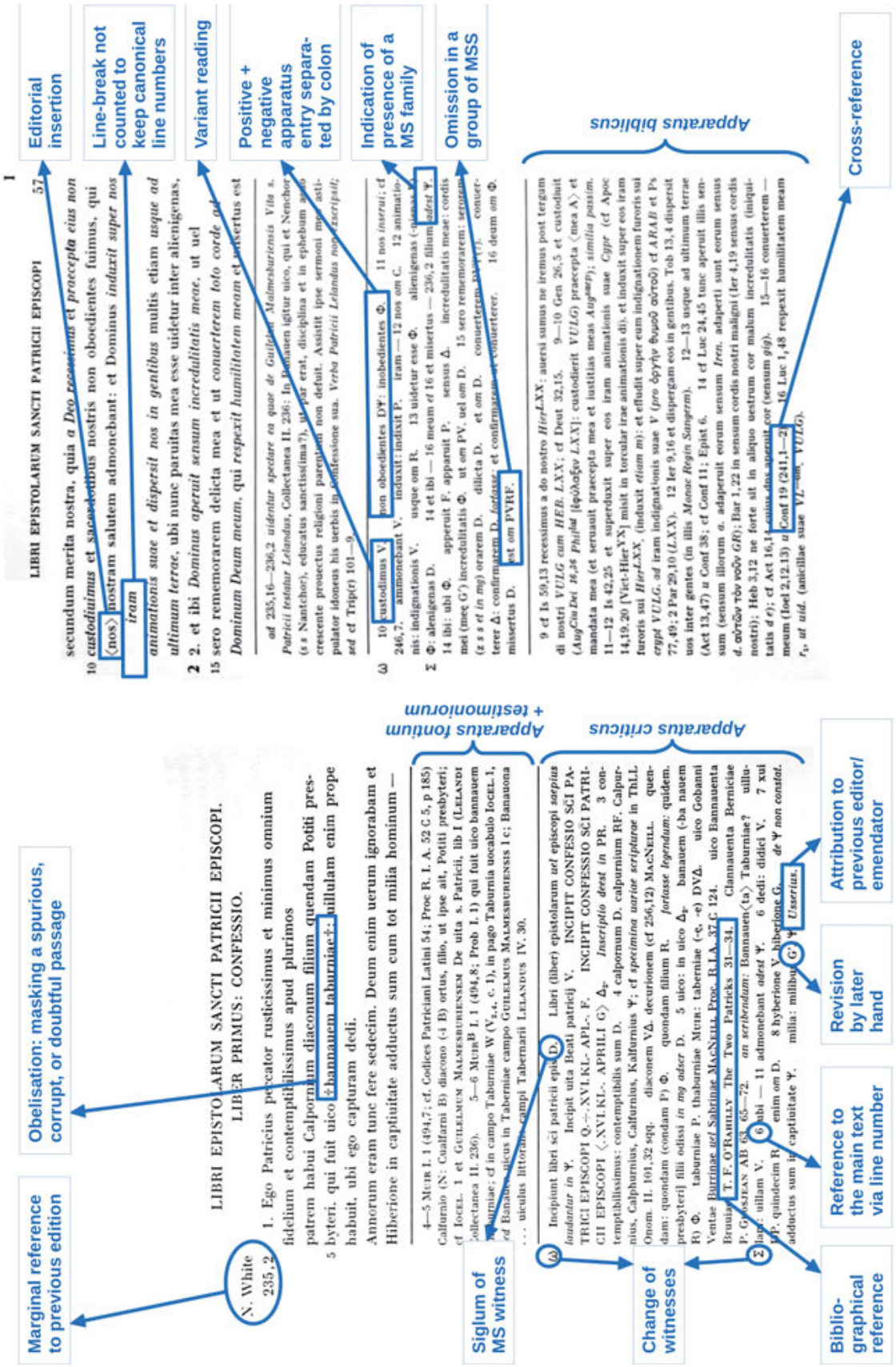

Fig. 6.3-5: Features of a critical text: the beginning of St Patrick's Confessio with a threefold apparatus (Bieler 1950, 56-57). "MS(S)" stands for "manuscript(s)" in the figure. () 1993 the Royal Irish Academy, reproduced by permission. 
is not chosen, in the base text or chosen "best text") and obeli, or cruces (†... ${ }^{+}$, to mark a word or passage that is corrupted or spurious; a list of commonly used abbreviations and editorial signs along with short explanations is provided in the PLS (Roelli and Macé 2015, under "Abbreviations and Editorial Signs”; more signs and abbreviations can be found in e.g. Bernabé and Hernández Muñoz 2010, appendix 1; Tarrant 2016, 164-166; Bourgain and Vielliard 2002, 86-87; Dondaine 1960).

\subsubsection{Unity of content and form}

The way the critical text is presented is inseparable from its very nature. Content and form constitute the unity of the critical text. The essence of the critical text is realised with a clearly designed page layout for the actual text and its critical framework of apparatus(es) and marginal references, set in print. Usability and readability depend on its static presentation. Where a canonical work structure (such as chapters and verses of biblical books or classical works) is missing, contingent page breaks and line numbers are canonised in order to serve as stable reference points both for internal and external references as well as for citation.

\subsubsection{Digital editions}

\subsubsection{The digital paradigm}

Digital editions are "guided by a digital paradigm in their theory, method and practice” (Sahle 2016, 28). What is this digital paradigm? It can be defined by a number of differences and innovations compared to its predecessor, the print paradigm. The static text in print can be contrasted with the fluidity of texts in the ever-changing formats of software and devices, apparently with dramatic consequences for established practices and scholarly conventions of referencing and citation. Published online, they can be accessed by anyone at any time in any place connected to the World Wide Web. Overcoming the limits of space and the medial restrictions of the book, large amounts of textual material, digital images, and even audio and video content can be included. In fact, the provision of digital facsimiles, descriptions, and transcriptions of the textual witnesses has become a common feature of digital editions. Hypertextuality allows for interlinking and instant browsing between different textual layers and components both internal and external to the edition or resource. Mark u p enables enrichment of transcripts with palaeographical details and codicological information; structural markup of paragraphs, lines, and other kinds of textual sections or segments supports precision in addressing, accessing, presenting, and extracting textual data at any degree of granularity, that is, at any level of detail, from words or even characters to any semantic, grammatical, or other structural unit of a text. Linguistic and semantic markup allows statistical analysis and evaluation of the grammatical and stylistic characteristics of a particular author, work, or genre. In the print era, scholarly editing was concerned with 
the creation of a final and definite product - even if most textual editors were and are conscious that their texts are a scholarly hypothesis about a text, and that their print editions will not remain satisfactory for ever but will be outdated after "one or two generations, with fifty years an especially long life” (Tarrant 2016, 145-146). In the digital era, however, pre-publications of beta versions can be updated with corrections and additions of further material, transcriptions, variant readings, comments, enriched metadata, and textual markup, again regardless of the consequences concerning practices and conventions of quotation and referencing. Accordingly, the nature of a digital edition can be described as a process, not a product. Open formats ensure that research data such as digital images and texts can be used independently from proprietary platforms and shared via common software environments facilitating various ways of efficient collaboration between individual textual scholars, research teams, and wider communities. However, the most fundamental difference between printed and digital editions can be described in terms of the representation of content as data and its presentation in various and alternative publication formats.

\subsubsection{Representation vs presentation}

The current transformation of textual scholarship and scholarly editing is not primarily a change in publication format, from print to the Web, but a change for which the term "transmedialisation" has been coined (Sahle 2010, 31). As mentioned above (6.3.2.3), the unity of content and form is characteristic of textual scholarship and the scholarly edition of the print era. In contrast, digital scholarly editions are going beyond single medial realisations. Characteristic of textual scholarship and scholarly editions of the digital age is the separation of content and form. Content is stored as data and metadata, that is, in the form of images, encoded text, markup, and annotation, and represented in the way the data is modelled in data formats and data models (see 3.4). This content is represented (stored) in a format that is clearly distinct from its form and appearance - the way it is presented on screen, in print, or in other formats of presentation such as variant graphs or tables (see 3.3), networks, lists or statistical charts, the search interface of a database, a hypertext or, in fact, a book. Transmedialisation is the representation of information, documents, and texts without determining a publication format. With regard to the critical text of a digital edition, this might mean that all critical annotations, lemmata, variant readings, sigla, and references are encoded in order to create sets of data on the representational level that are machine-readable, processable, and, ideally, interoperable and interchangeable. Ideally, one would follow the guidelines of the Text Encoding Initiative (tei-c.org), which are generally regarded as the de facto standard for text encoding. In fact, chapter 12 of the TEI guidelines defines a module for use in encoding an apparatus criticus. But to encode an apparatus criticus is to encode a phenomenon inherited from the print era, whereas digital textual scholars seek to go beyond what is seen as merely one pos- 
sible physical embodiment of the editorial arguments and decisions about the textual tradition. For this, further revisions and refinements of the encoding method and data model seem necessary in order to create an even more coherent abstraction of textual criticism itself.

\subsubsection{Digital approaches towards the critical text}

The field of digital critical editions is still in an experimental state, and it may always remain this way owning to the dynamic and ever-changing nature of digital technology. Still, the advantages of digital data-representation formats for the analytical potential of scholarly editions are obvious: access, space, functionality, revisability and progressive enrichment, and linkage to, inclusions of, and integration into other knowledge resources on the one hand, and searchability, processability, and quantitative evaluation of data on the other. Even if the development of stemmatology and the production of critical texts is closely connected to and shaped by the technology of print culture, an insistence on or return to the book as the decisive or even exclusive publication format seems to be out of the question. Hybrid publication models, on the other hand, providing an edition in both formats, digital and print, each of which compensates for the shortcomings of the other, may seem desirable for some texts and attractive to textual scholars and publishers alike, at least for a transitional period of time while new scholarly practices need to be adopted (e.g. for the quotation of revisable digital resources) and technical, or rather, institutional solutions (including to serious problems such as long-term availability) need to be implemented.

Textual scholars, scholars in the digital humanities, and software developers have produced a wide range of digital methods, tools, and formats for representing historical texts and textual transmission (see the overviews on the theories and practices of digital scholarly editing by Sahle 2013, esp. vols 2-3; Apollon, Bélisle, and Régnier 2014; Pierazzo 2015). Various strategies have been applied for transferring and enhancing scholarly standards and conventions of critical editing into a digital setting. Some of the most significant approaches will be presented in the following. It should be noted, however, that the practical realisations of digital scholarly editions usually implement and combine aspects of several approaches.

\section{Reproduction}

First of all, plain digital reproduction of an existing print edition is a common part of larger retro-digitisation campaigns such as the Internet Archive (archive. org), the Open Library (openlibrary.org), or even the commercial Google Books (books.google.com). If provided with accurate metadata and OCR-generated electronic text versions, these digitised editions can already prove very useful, especially with regard to accessibility and searchability (figs 6.3-1 and 6.3-4 above are a case in point). 


\section{Imitation}

Second, digital editions have been imitating the print paradigm regarding the selection and presentation of their content. Nowadays, the creation of critical editions adhering to the presentation standards and requirements of print editions can be realised with the free software package LaTeX - more precisely, with the reledmac package for typesetting scholarly critical editions (ctan.org/pkg/reledmac; see 6.4.1), which supports the creation of multiple apparatuses by indexing page and line numbers (see 6.4.1). Realised as static and printable PDF documents, such editions also exploit a number of beneficial functionalities in digital documents. They are fully searchable, cross-references and external references can be realised as hyperlinks, and they can be shared and published independently from application software, hardware, and operating systems (for alternative software packages, see wiki.contextgarden.net and tustep.uni-tuebingen.de; see also 6.3).

Often, digital publications of critical texts do not significantly exceed print formats in terms of content and functions. While editions such as the meritorious edition of Euripides Scholia by Donald J. Mastronarde (euripidesscholia.org) are critically annotated and digitally presented, the established texts are plain and onedimensional from a technological point of view. Even if based on TEI XML-encoded source files, the semantic value of the markup does not allow for more advanced functionalities, visualisations, or in-depth analysis of the critical annotations. Still, even relatively flat data files offer an opportunity for further enrichment. Other digital editions are based on the layout-oriented XML output of the Classical Text Editor (CTE; see 6.4.1), such as the Kleine und fragmentarische Historiker der Spätantike [Fragments and Testimonies of Historians from Late Antiquity] edition (2016-), which was originally conceived as a print edition.

\section{The renunciation of a single established critical text: Multi-witness editions}

A far more innovative approach has been taken by one of the founding fathers of digital critical editing, namely Peter Robinson, with the edition of The Wife of Bath's Prologue from Geoffrey Chaucer's Canterbury Tales, a Middle English work from the end of the fourteenth century. Published on CD-ROM in 1996, this multi-witness edition aimed to create a comprehensive record of the textual transmission by transcribing and collating fifty-eight of the eighty-eight pre-1500 manuscripts and incunabula. Closely interlinked and fully searchable, all witnesses were presented as digital facsimiles and TEI-encoded transcriptions in both regularised and unregularised spelling; information on the parts of speech of individual words was given. However, instead of critically reconstructing an archetype version, "a very lightly edited" (Robinson 1996b, CD-ROM Manual, 30) version of the oldest manuscript witness, the Hengwrt manuscript $(H g)$ served as a "base text" which could be read against any of the other fifty-seven witnesses by means of automated word-by-word collations (fig. 6.3-6). Accordingly, Robinson refrained from creating a stemma codicum to trace the witnesses back to some original version or archetype, and created 


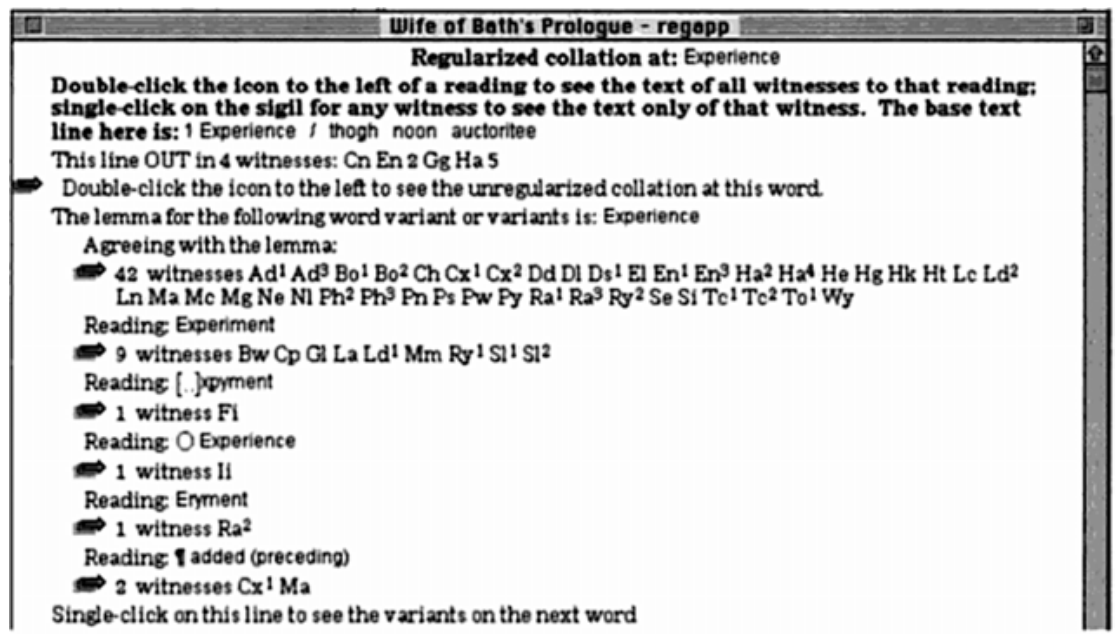

Fig. 6.3-6: The digital edition of The Wife of Bath's Prologue: apparatus entry resulting from the regularised collation for the word "Experience". Source: Robinson (1996b, CD-ROM Manual, 30).

a phylogenetic tree instead in collaboration with evolutionary biologists. The phylogenetic analysis limits itself to drawing conclusions about the genealogical closeness and distance of witnesses and witness families (Barbrook et al. 1998).

The digital edition of The Wife of Bath's Prologue set new standards for the representation of multi-witness works, especially as regards the amount of textual information and the accuracy of details. Several later editors would follow this paradigm, especially those of iconic vernacular mediaeval or early modern works of some national interest, providing facsimiles and transcriptions of the witnesses to be aligned and automatically collated, and critically annotated, but deliberately not providing a critically reconstructed version. Therefore, according to the definition used in this handbook, Robinson's edition of The Wife of Bath's Prologue cannot be called "critical" in a strict sense, that is, if a critical edition by definition is supposed to provide a critically reconstructed text by applying a genealogical methodology (see 6.3.1). If, however, the term "critical" is used in a wider sense, meaning that the base text (e.g. the transcript of a principal manuscript witness) is critically annotated (i.e. in a scholarly, rigorous manner) with information on variation, sources, and historical and philological details and explanations, enabling (at least in principle) any reader to critically assess any established version, then it definitely is.

Another multi-witness edition, created in collaboration with Peter Robinson and his team, is Prue Shaw's digital edition of Dante's Divina Commedia, providing electronic versions of the most important previous editions as well as facsimiles and transcripts of some of the most relevant manuscript witnesses, enriched with markup on metre. A sophisticated collation tool called VBase, along with stemmatic visualisations, enables the reader or user to critically assess any established and published critical text version (Shaw 2010; see also Spadini 2015). 


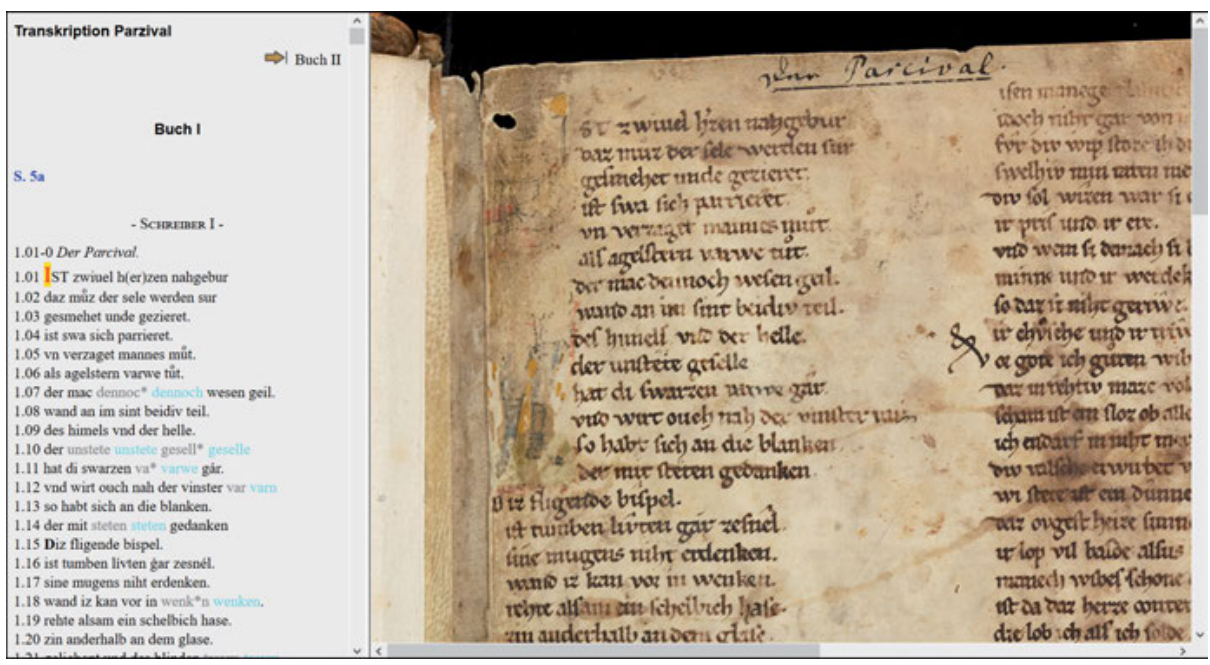

Fig. 6.3-7: Parzival-Projekt (2018): facsimile and transcription of the principal witness, $D$ (St. Gallen, Stiftsbibliothek, Cod. Sang. 857, thirteenth century). Manuscript page: e-codices.unifr. ch/en/csg/0857/5; font size and colour indicate palaeographical features. CC-BY-NC. () ParzivalProjekt Universität Bern.

Yet another example is Michael Stolz's digital edition of Wolfram von Eschenbach's Parzival (fig. 6.3-7), again emphasising the variety of this work's transmission. In the spirit of the so-called "new" or "material" philology, the project began with detailed transcriptions of the important witnesses (fig. 6.3-8). However, in an attempt to reconcile Bédier's schism (Trovato 2017, 77-108), the edition aims to synthesise opposing philological perspectives, establishing a single critical text (fig. 6.3-9) as well as a synoptic edition of four versions, following the concept of Fassungen developed by Joachim Bumke.

The Parzival project has experienced a development from archive to edition similar to that of another pioneering project, the Piers Plowman Electronic Archive (PPEA, piers.chass.ncsu.edu). As early as 1994, the PPEA was conceived as a complex digital collection of the full textual tradition of Piers Plowman, a fourteenth-century allegorical dream vision attributed to William Langland, witnessed by more than fifty manuscripts. The electronic archive would:

eventually consist of hypertextually linked documentary editions of every manuscript; edited texts of hyparchetypes and archetypes; critical texts of versions A, B, and C; facsimiles of all witnesses; and an apparatus criticus for each text to include codicological, palaeographic, linguistic, lexical, and textual annotations. (Duggan and Lyman 2005, §5)

After initial publications of documentary editions and facsimiles on CD-ROM, the archive grew, and is still growing, into a critical online edition reconstructing three distinct archetypal versions of the poem (figs 6.3-10-11). 


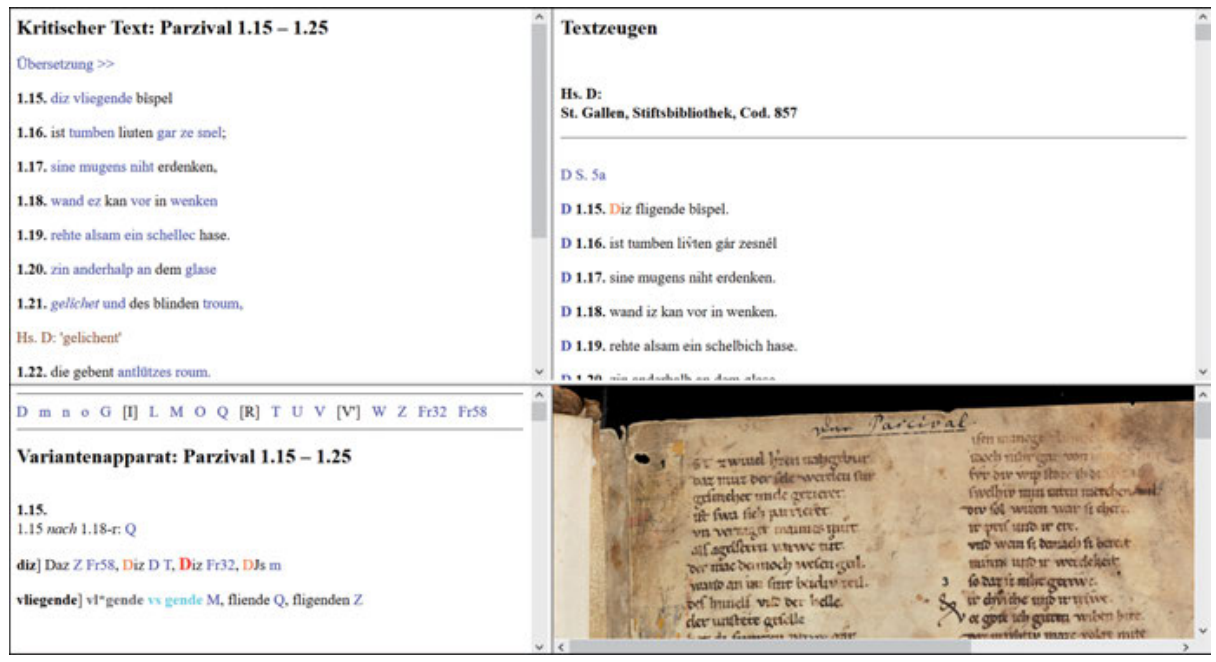

Fig. 6.3-8: Parzival-Projekt (parzival.unibe.ch): critical single text following the main manuscript, $D$. In the upper left-hand window is a normalised text, in the lower left-hand window is the apparatus of variant readings, and on the right are transcriptions and facsimiles of the various manuscript witnesses. ( $)$ Parzival-Projekt Universität Bern.

\begin{tabular}{|c|c|c|c|c|c|}
\hline$D=n$ & $\mathbf{T}$ & $\begin{array}{lllllllllll}\text { U } & V & w & Z & 9 & 14 & 29 & 32 & 36 & 55\end{array}$ & Dreliger $*$ & D $D * G$ "T 4 Fassungen & \\
\hline -D 19.01 aht ors mit zindale & & ${ }^{\prime m} 19.01$ aht ros mit zindsle & $\hat{A} \cdot G 19.01$ abt ons mir zendale & A ${ }^{-T} 19.01$ ahte ors mit zindale & \\
\hline -D 19.02 verdecket al ze mille. & & "m 19.02 verdecket alliu zuo mále. & "G 19.02 verdecket al ze malle. & -T 19.02 verdecket al ze mile. & \\
\hline -D 19.03 daz niubde sinen satel truoc. & & "m 19.03 daz mund sinen satel truoc. & *G 19.03 daz niunde sinen satel truoc. & -T 19.03 daz niunde sinen satel truoc. & \\
\hline "D 19.04 ein schilt, des ich é gewuoc, & & "m 19.04 einen schilt, des ich é gewuoc, & "G 19.04 einen schilt, des ich é gewroc, & "T 19.04 einen schilt, des ich é gewuoc, & \\
\hline -D 19.05 den vuorte eia knuppe vil gemeit & & "m 19.05 den vuorte ein knappe vil gemeit. & ${ }^{*} G 19.05$ vuorte ein knappe vil gemeit. & -T 19.05 dea vuorte ein knappe vil gemeit & \\
\hline -D 19.06 der bi. nâch den selben reit & & "m 19.06 do noch bi dem selben reit & •G 19.06 dả hinden nâch dem selben reit & ${ }^{-T} 19.06$ dả bi. nàch dem selben reit & \\
\hline -D 19.07 pusùner, der man noch bedarf. & & "m 19.07 pusùner, der man och bedarf. & "G 19.07 busutnare, der man ouch bedarf. & -T 19.07 pusinere, der man ouch bedarf. & \\
\hline -D 19.08 ein tambilrer sluog und warf & & "m 19.08 ein tambürer slooc und warf & "G 19.08 ein tambûrer sluoc und warf & ${ }^{-T} 19.08$ ein tambùrer sluoc und warf & \\
\hline -D 19.09 höbe sine tambür. & & "m 19.09 vil bóbe síne tambûre. & "G 19.09 vil höbe sinen tambêr. & -T 19.09 vil höhe sinen tambür. & \\
\hline -D 19.10 den hêrrea nam vil untâr, & & "m 19.10 den hêrren nam vil untîre, & "G 19.10 den betren nam vil untût, & 'T 19.10 den betreen nam vil untûr, & \\
\hline -D 19.11 dáne riten floitierre bi & & ${ }^{\prime} \mathrm{m} 19.11$ deane riten floitierre bof & ${ }^{-} \mathrm{G}$ 19.11 da riten floitierare bi & ${ }^{-T}$ 19.11 da enriten floitere bi & \\
\hline -D 19.12 und guoter videlere dri. & & ${ }^{\prime} \mathrm{m} 19.12$ und guoter videlere dri. & "G 19.12 unde walscher videlere dri. & -T 19.12 und welscher videlere dri. & \\
\hline -D 19.13 den was allen niht ze gich. & $\checkmark$ & "m 19.13 den was allen niht zoo gich. & *G 19.13 den was allen niht ze gách. & -T 19.13 den was allen niht ze gich. & 2 \\
\hline $\begin{array}{l}19.01 \\
\text { aht ] Achne Fr9 }\end{array}$ & $\hat{\mathrm{E}}$ & $\begin{array}{l}19.01 \\
\text { mit ] mit mit o }\end{array}$ & $\hat{[}_{\text {mit ] von G }}^{19.01}$ & $\hat{E_{i}} \begin{array}{l}19.01 \\
\text { mit ] von U }\end{array}$ & $\hat{\imath}$ \\
\hline $\begin{array}{l}19.04 \\
\text { ein ] Eynen Fr9 } \cdot \text { ich ] om. D • gewuoc ] }\end{array}$ & & $\begin{array}{l}19.02 \\
\text { alliu zoo ] ale zů } \mathrm{m} \text { alzí n o }\end{array}$ & 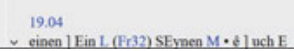 & $\begin{array}{l}19.03 \\
\sim \text { niunde ] in vnd U }\end{array}$ & \\
\hline
\end{tabular}

Fig. 6.3-9: Parzival-Projekt (parzival.unibe.ch): synoptic view of ${ }^{\star} D,{ }^{\star} m,{ }^{\star} G$, and ${ }^{\star} T$, the four versions of Parzival, along with critical apparatus. Clicking on a siglum opens a window displaying the transcription and facsimile of the respective manuscript witness. (C) Parzival-Projekt Universität Bern. 


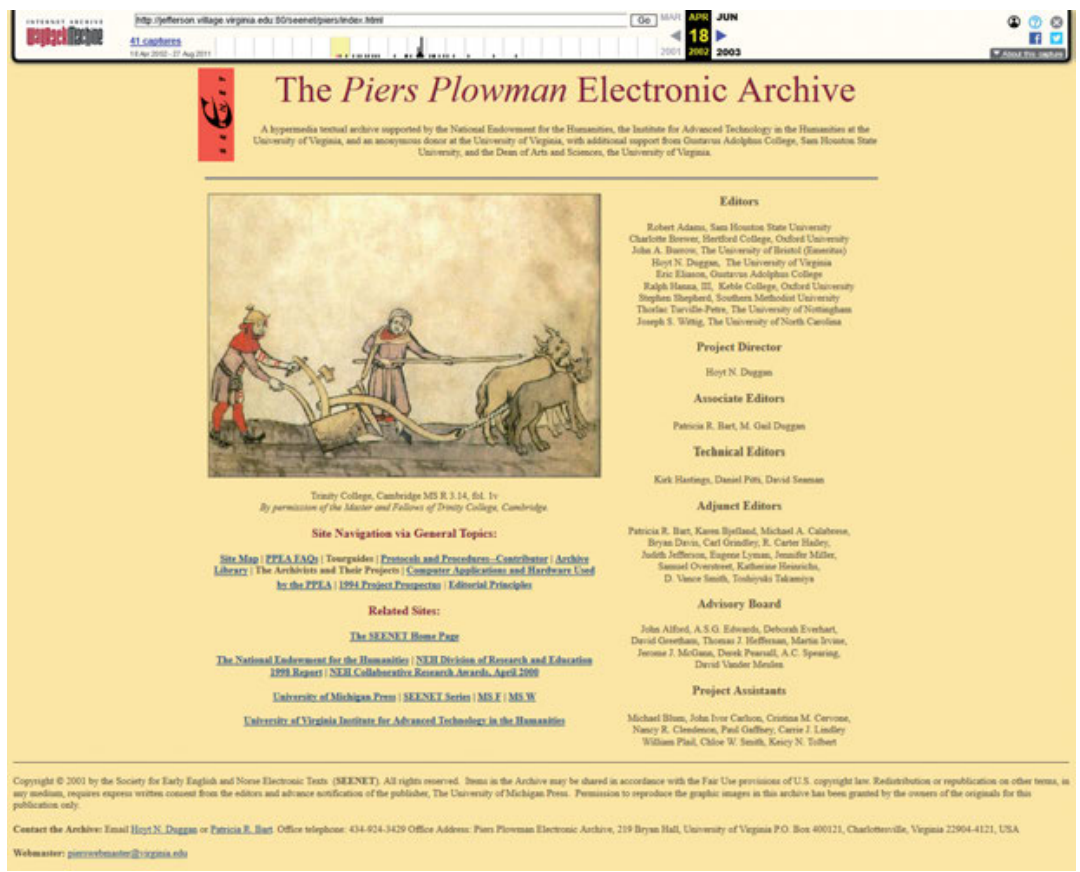

Fig. 6.3-10: The website of the Piers Plowman Electronic Archive from April 2002, accessed through the Internet Archive's Wayback Machine (web.archive.org/web/20020418175917/http://jefferson. village.virginia.edu:80/seenet/piers/index.html). () Society for Early English and Norse Electronic Texts (SEENET).

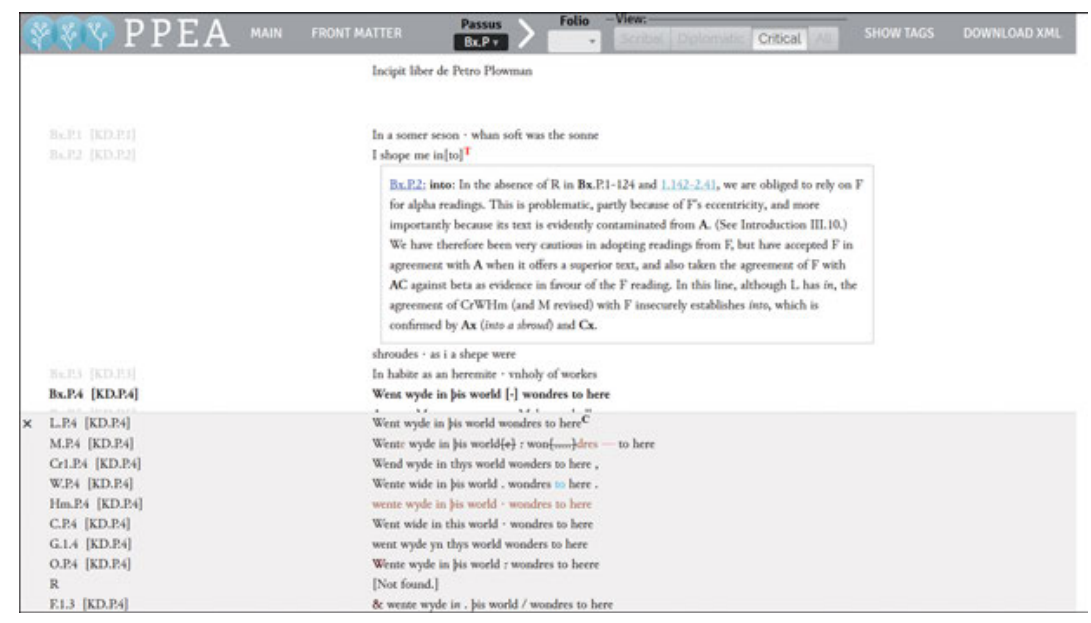

Fig. 6.3-11: Critical text of the $B$-version archetype of Piers Plowman in the electronic archive (as of 2017), with the option to display critical apparatus notes and synoptic views of diplomatic transcriptions of variant verses (linked to full transcriptions and facsimiles). (C) Society for Early English and Norse Electronic Texts (SEENET). 


\section{Amplification}

Similarly, following a pluralistic notion of text (Fischer 2008, §27-38), the digital edition of St Patrick's Confessio presents a variety of textual layers by amplifying the canonical print edition by Ludwig Bieler from 1950 (see fig. 6.3-5 above). By hovering over an apparatus entry, the referenced lemma is highlighted in the base text (fig. 6.3-12). In the apparatus, all sigla of individual witnesses are linked to the digital facsimile of the relevant folio (fig. 6.3-13); abbreviations and sigla of witness families are expanded by hovering the cursor over them; other signs, symbols, and abbreviations are linked to a key with definitions and descriptions; bibliographical references are linked to a comprehensive bibliography, biblical references to external online versions of biblical books; and testimonia are linked to the texts of Patrick's two earliest biographers, Muirchú and Tírechán, which are also included in the edition. Through the further inclusion of facsimiles of all relevant editions that have been printed since the publication of the editio princeps from 1656 (among them a diplomatic and a facsimile edition of the oldest manuscript witness, the early ninth-century Book of Armagh), the critical text becomes just one, albeit the central, textual layer in a virtual stack of closely interlinked textual layers representing all aspects of the work's transmission (Fischer 2013).

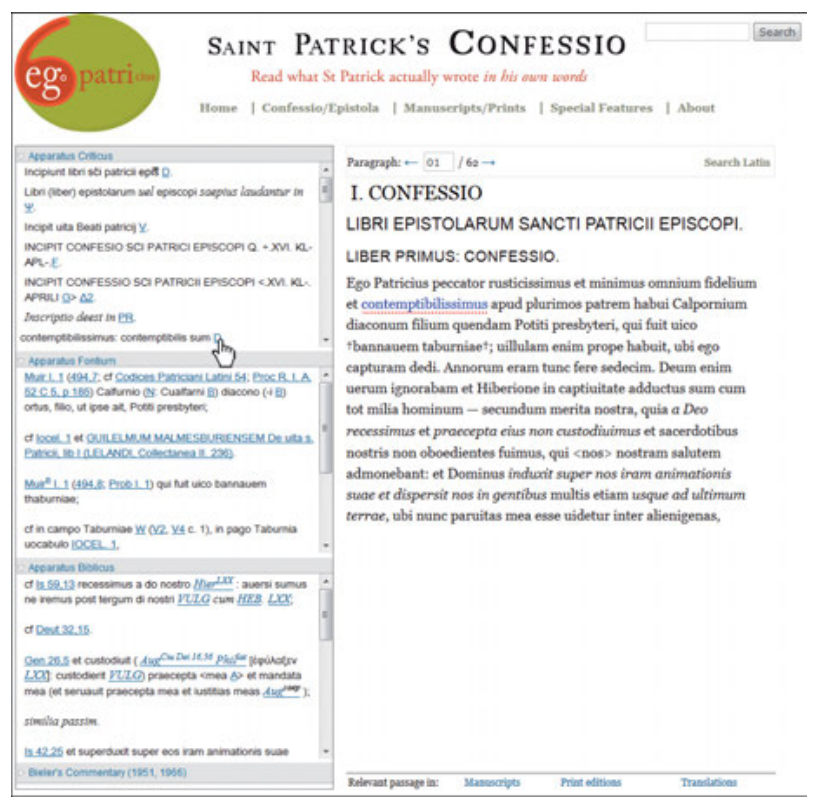

Fig. 6.3-12: The digital critical text of St Patrick's Confessio with a threefold apparatus and commentary closely interlinked with facsimiles and further resources included in the edition based on the critical text of Ludwig Bieler's print edition from 1950 (see fig. 6.3-5 above). Source: Anthony Harvey and Franz Fischer (eds.), The St Patrick's Confessio Hypertext Stack (www.confessio.ie). Dublin: Royal Irish Academy, online since September 2011. 


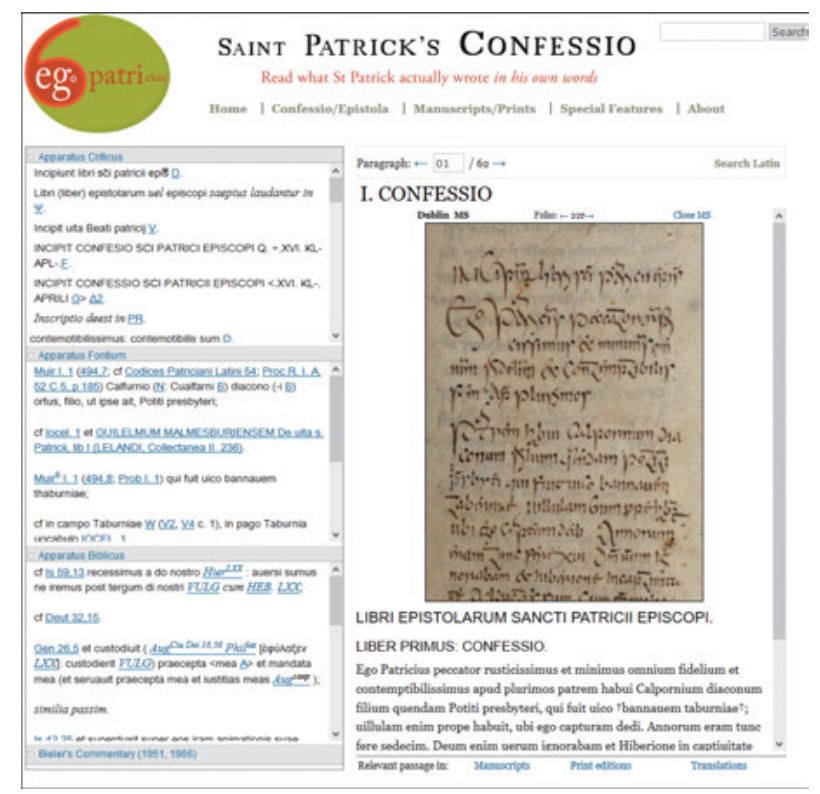

Fig. 6.3-13: The critical text of St Patrick's Confessio along with the facsimile of $D$ (Book of Armagh, 808/809). Source: confessio.ie/etexts/confessio_latin\#01.

\section{Collaborative, peer-sourced, and progressive editing}

The mantra of software developers, "release early, release often" (Raymond 1999), has been adopted by Jeffrey C. Witt in his critical edition of the lectures on Peter Lombard's Sentences by Peter Plaoul (1353-1415) - a progressive editio n publishing a draft version of the critical text (or rather critical text to be) even before establishing a stemma codicum (fig. 6.3-14). Both the editor and the registered reader (or rather collaborator, or even co-editor) are able to leave comments on particular sections and to suggest additions or corrections of variant readings from relevant witnesses for the critical apparatus. Depending on the availability of transcripts, automated collations of paragraphs can be executed at any time (Witt 2011; see also Vasold 2014; Dunning 2015).

In connection with the Canterbury Tales Project 2 (wiki.usask.ca/display/CTP2/ Canterbury+Tales+Project $+2+$ Home, a follow-up to the edition of Chaucer's The Wife of Bath's Prologue mentioned above), a software environment for the collaborative online creation of scholarly editions called Textual Communities (textualcommun ities.org) has recently (2018) been launched, aiming at completing transcriptions of all remaining pre-fifteenth-century witnesses, a laborious task to be accomplished through the joint efforts of an open community of Chaucer scholars and interested students and citizens (Robinson 2017).

A third example of collaborative and progressive editing is the Nestle-Aland edition of the Greek New Testament (Novum Testamentum Graece), which has func- 


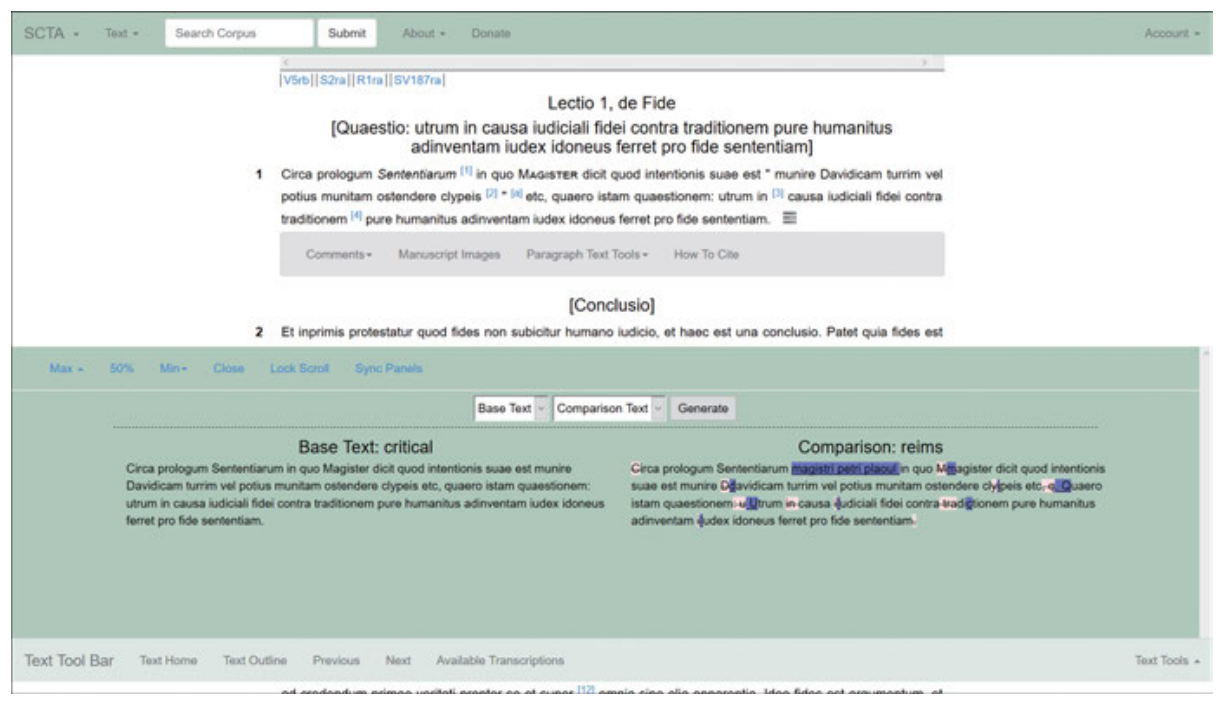

Fig. 6.3-14: Jeffrey C. Witt's edition of Petrus Plaoul's commentary on the Sentences. For each paragraph, comments, images, and a series of text tools can be opened (here, an integrated collation tool comparing the critical text with a witness from Reims). A disclaimer at the top of the page (not shown here) reads: "Please remember: the status of this text is draft. [...] Please use the comments to help make suggestions or corrections." Source: scta.lombardpress.org (Scholastic Commentaries and Texts Archive; SCTA). CC-BY-SA.

tioned as a catalyst for the development of textual criticism in a scholarly tradition beginning with the edition of Erasmus in 1516. The authoritative Nestle-Aland edition published in print by the Institut für Neutestamentliche Textforschung saw its twenty-eighth revision in 2012. The editorial work is ongoing, extended by the Novum Testamentum Graecum - Editio critica maior (ECM), listing a more complete set of variants and nowadays mainly supporting two digital projects: (a) the application of the Coherence-Based Genealogical Method (CGBM; see 5.3.7.3) to calculate the relations of each witness at any given place, with the final goal of a global stemma, as part, in principle, of an endless hermeneutical process of improving the genealogical hypothesis about the initial text and its history (Wachtel 2012a, 223-224; Mink 2012; see 7.1.2 below); and (b) the open digital editing environment of the New Testament Virtual Manuscript Room (ntvmr.uni-muenster.de), which provides a growing repository of images of more than five thousand Greek manuscripts and an open workspace for the preparation of transcriptions to be integrated into the editorial workflow and, ultimately, into the digital edition (to complement the definitive printed version of the ECM).

\section{Distributed architecture for digital editions}

More recent concepts and technological innovations point in the direction of a distributed architecture for the digital edition. Joris van Zundert (2018; see also Witt 
2018) argues in favour of networked resources as opposed to resources that tend to subsist as isolated and monolithic data silos. An example of this is the new software application called Mirador, designed to operate on a community-driven reference standard/protocol, the International Image Interoperability Framework (IIIF). Adopted by a growing number of research libraries with manuscript collections, IIIF makes it possible to query images of manuscript folios, as well as other visual media, directly from library servers across the world. This approach, as exemplified most expediently by the Mirador viewer, plays a pivotal role in what may be seen as yet another "paradigmatic shift in how we understand, approach and interact with cultural heritage resources" (van Zundert 2018), and thereby how we conceive digital critical editions in the future. Again, the above-mentioned critical edition by Jeffrey C. Witt is playing a pioneering role by introducing the Scholastic Commentaries and Texts Archive (scta.info), a publication framework and Web service for digital editions which makes it possible to query text files and facsimiles from distributed databases and repositories. A necessary requirement for this organisation and publication of content is the development of field-standard data models that can make all textual and image data accessible in predictable ways to data-consuming applications (Witt 2018). It is for this very reason that the primacy of the data model is also advocated in the context of the Digital Latin Library project (digitallatin.org) as a prerequisite for the creation of intuitive and powerful interfaces for reading digital critical editions online (Cayless 2018).

\subsubsection{Future perspectives}

Digital philology has developed a wide range of models for scholarly editions and the critical representation of textual transmission. Further development of digital presentation and publication formats for critical texts (as a result of genealogical and stemmatological methods) will largely depend on the establishment of editorand user-friendly work environments and publication frameworks. Through the integration of interactive tools that are especially designed for the analysis and visualisation of textual variation - e.g. as graphs, heat maps, or collation tables - such as CollateX, Juxta, Stemmaweb, CATview, and so on (see 5.4 above; see also Barabucci 2016), usability and attractiveness might increase even for more traditional, that is, print product-oriented editors. However, such advancements should be accompanied by an extension of the traditional skill set of critical editors and textual scholars, at least regarding text encoding and the formalisation of editorial practices.

The successful and advantageous use of digital tools and presentation formats, then, also depends on whether editors following genealogical or stemmatological methodologies are interested, intrinsically or extrinsically, in widening their research agenda to include other textual aspects (Monella 2012). Digital editions are 
particularly strong when it comes to the integration and interlinking of large amounts of textual material, including digital facsimiles and transcripts of relevant documents, as well as multiple versions of one particular text following different degrees of normalisation and regularisation. This may also include, among other things, having a synthetic or critical text version as the final aim of the editorial process. The data underlying these textual layers can be enriched with palaeographical, structural, linguistic, semantic, or metrical information, each of which supports different research questions and allows for alternative perspectives on the same text. But an increase in textual complexities, in turn, affects usability, especially as regards one of the most basic requirements for scholarly editions, namely addressability and citability. Either way, the scope of editorial decisions to be made has widened significantly. The decision about the optimal type of edition will always be determined by various and different factors such as, most importantly, the textual material at hand and its transmission, but also the time and financial resources available, skills, technical support, and not least the editor's individual understanding of textual criticism and how to make sense of textual transmission - all against the background of the technical conditions and intellectual paradigms in any given time and place.

The future of digital editions depends, finally, on technical and institutional solutions that address sustainability and long-term preservation concerning the curation of both data and applications. Whereas we seem to be relatively safe when it comes to archiving and preserving data in standardised models and formats, crucial issues remain problematic when it comes to software and technical infrastructure for keeping digital editions alive and accessible. Only a very few humanities research institutions, if any, are capable of what has been labelled Research Software Engineering (RSE) and to continuously maintain complex digital resources. Different approaches are being implemented, combined, and discussed, from dedicated portals and repository solutions, to formalised documentation and testing procedures, to the promotion of modularised technical architectures (Bleier et al. 2018; Dängeli 2019). Coordinated efforts on the organisational level between research institutions across local, regional, or national borders might open the way to a more sustainable infrastructure for digital critical editions.

\subsection{Publication of digitally prepared editions}

Tara Andrews

It will have become clear to the reader by now that the digital world has a great deal to offer not only for methods of stemmatic analysis of texts, but also for their editing and presentation. That said, digital tools in the humanities require a rela- 
tively high level of technical understanding and engagement, and the online publication of critically edited texts is no exception to this. At first glance, there would appear to be great demand among textual scholars for a software package or a suite of tools, akin to WordPress for websites, that would allow easy and straightforward publication of scholarly editions. When software developers in the humanities attempt to address this demand, however, we very quickly find that the seemingly unanimous demand is, in fact, a cacophony of individual demands, each different in its details.

This section will not be a survey of individual publication tools. Such a section would be unrepresentative, given the large number of online editions whose publication was the result of a custom development effort. It would also immediately be incomplete, and very quickly obsolete. Rather, we will survey here the different forms of digital publication that are possible, discuss the technologies behind them and the sort of institutional support that would be required to adopt them, and where appropriate - give examples of tools where they exist for each category.

\subsubsection{Print-ready solutions}

In many circumstances, an edition that has been created digitally must be published in print - perhaps as the appendix to a thesis or dissertation, a journal article, or a submission to an edited series. In this case, the editor will prefer a tool that can handle typesetting or conversion to a document format that will be accepted by a publisher.

Perhaps the best-known software package for critical edition preparation and publication is the Classical Text Editor program (also known as CTE), which functions as a sort of word processor for editions (Hagel 2007). CTE has been under active development since 1997, and is widely used by textual scholars, although it only runs on the Windows operating system and its use requires purchase of a license. Its focus is very much on the preparation of critical edition text for print publication, with output available as PDF, TEI XML, or static HTML. Recent versions of CTE provide the possibility to import individual text transcriptions for automated pairwise collation with a given base text, and to produce data on textual variation in a format suitable for use with many cladistic analysis programs.

Another option for print publication, and one that is accepted by many academic and commercial publishers, is to use the LaTeX typesetting system. LaTeX was developed in the early 1980 s as a document-focused variant of TeX, itself developed in the 1970s. The user creates a plain text file and uses a form of markup to indicate typesetting instructions - for example, to specify fonts or footnotes. The marked-up file can then be sent to a publisher as is, or passed to the TeX program for conversion to one of a number of formats, including, but not limited to, PDF (Portable Document Format). Although LaTeX does not by default use Unicode, this can be enabled either by use of the package inputenc or by use of the LaTeX variants XeLaTeX (for MacOS, using Apple's font system) or LuaTeX (for all operating systems). 


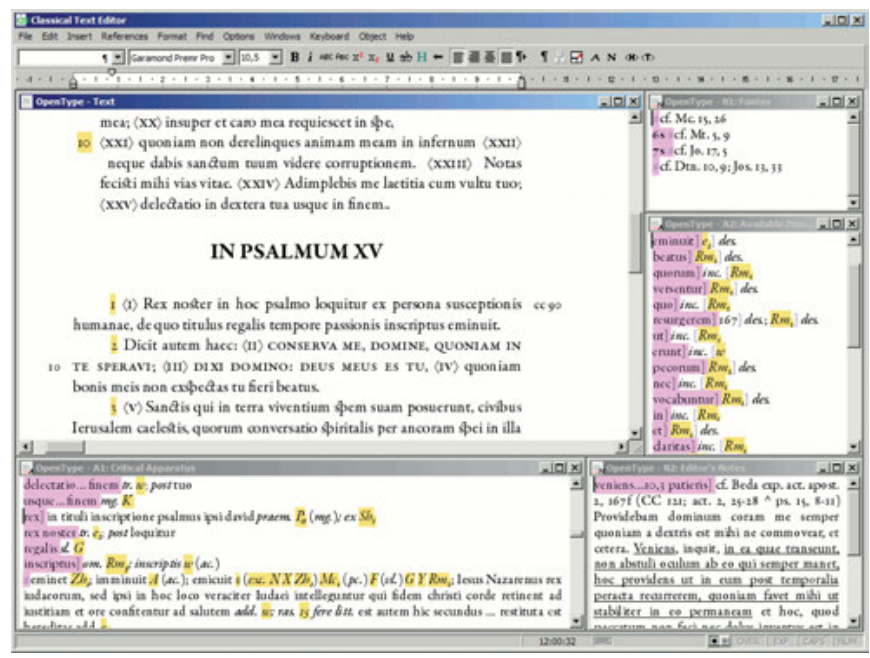

Fig. 6.4-1: The Classical Text Editor. Screenshot from cte.oeaw.ac.at.

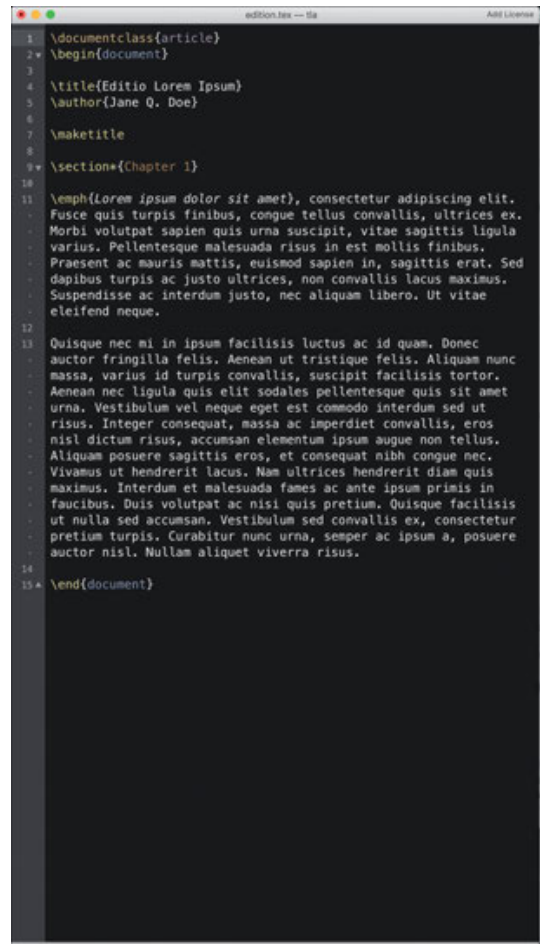

Editio Lorem Ipsum

Jane Q. Doe

December 20, 2018

\section{Chapter 1}

Lorem ipsum dolor sit amet, consectetur adipiscing elit. Fusce quis turpis finibus, congue tellus convallis, ultrices ex. Morbi volutpat sapien quis urna suscipit, vitae sagittis ligula varius. Pellentesque malesuada risus in est mollis finibus. Praesent ac mauris mattis, euismod sapien in, sagittis erat. Sed dapibus turpis ac justo ultrices, non convallis lacus maximus. Suspendisse ac interdum justo, nec aliquam libero. Ut vitac eleifend neque:

Quisque nec mi in ipsum facilisis luctus ac id quam. Donec auctor fringilla felis. Aenean ut tristique felis. Aliguam nune massa, varius id turpis convallis, suscipit facilisis tortor. Aenean nec liguh quis elit sodales pellentesque quis sit amet urasa Vestibulum vel neque eget est commodo interdum sed ut risus. Integer consequat, massa ac imperdict convallis, eros nisl dictum risus, accumsan Integer consequat, massa ac imperdict convallis, eros nis dictum risus, accumsun
elementum ipsum augue non tellus. Aliquam posuere sagittis eros, et consequat elementum ipsum augue non tellus. Aliquam posuere sagittis eros, et consequat
nibh congee nec. Vivamus ut hendrerit lacus. Nam ultrices hendrerit diam nibh congue nec. Vivamus ut hendrerit lacus. Nam ultrices hendrerit diam
quis maximss, Interdum et malesuada fames ac ante ipsum primis in faucibus. quis maximus, Interdum et malesuada fames ac ante ipsum primis in fascibus,
Duis volutpat ac nisi quis pretium. Quisque facilisis ut nulla sed accumsan. Vestibulum sed convallis ex, consectetur pretium turpis. Curabitur nune urna, semper ac ipsum a, posuere auctor nisl. Nullam aliquet viverra risus.

Fig. 6.4-2: A basic LaTeX example and the rendered result. 


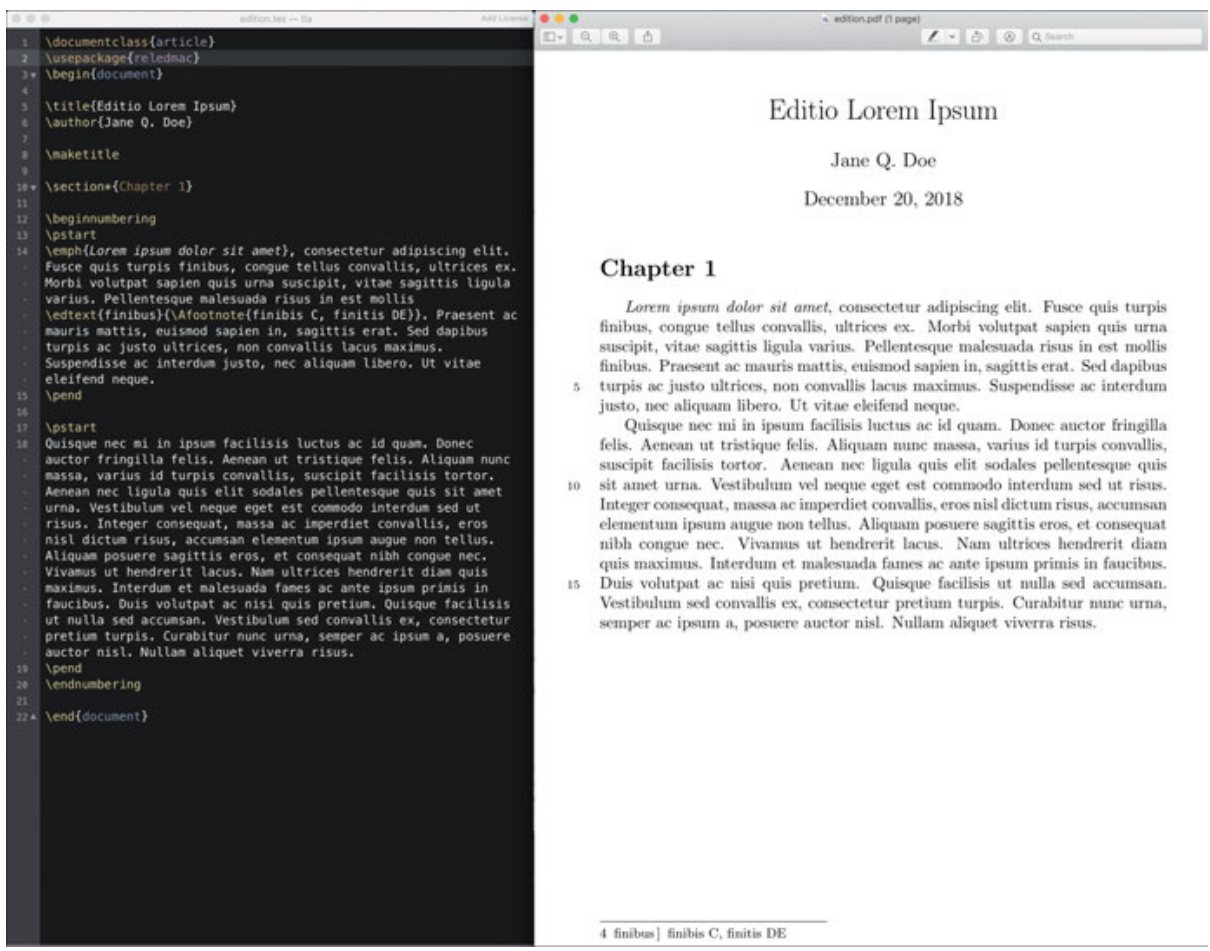

Fig. 6.4-3: Adding critical footnotes to the LaTeX example with the reledmac package.

Since LaTeX is free software, and is widely used in the scientific and scholarly community, a great many packages have been made available that extend its functionality. Two of these are reledmac and its sister package reledpar, developed by Peter Wilson and Maïeul Rouquette specifically for typesetting critical apparatus blocks and parallel text editions respectively (Rouquette 2018). These packages are based on an earlier package for TeX itself known as edmac (Lavagnino and Wujastyk 1996). The editor uses LaTeX markup to indicate lemma readings and provide apparatus entries for those readings; the package can support up to five apparatus blocks, either as footnotes or as endnotes.

Another increasingly popular format for writing texts, also based on a plain text format, is Markdown. Markdown, as its name implies, was created to provide as simple and intuitive a form of text markup as possible, one that is intelligible to a person who is looking directly at the source text. It is not a program or a piece of software, but rather a lightweight markup format that is used by an increasing number of software and Web platforms.

In combination with a program such as Pand oc (a "Swiss army knife" for conversion of document formats), Markdown can be a simple yet powerful strategy for producing a printed document in any necessary format, including but not limited to Microsoft Word, OpenOffice.org, EPUB, DocBook, HTML, LaTeX, PDF, and TEI XML. 


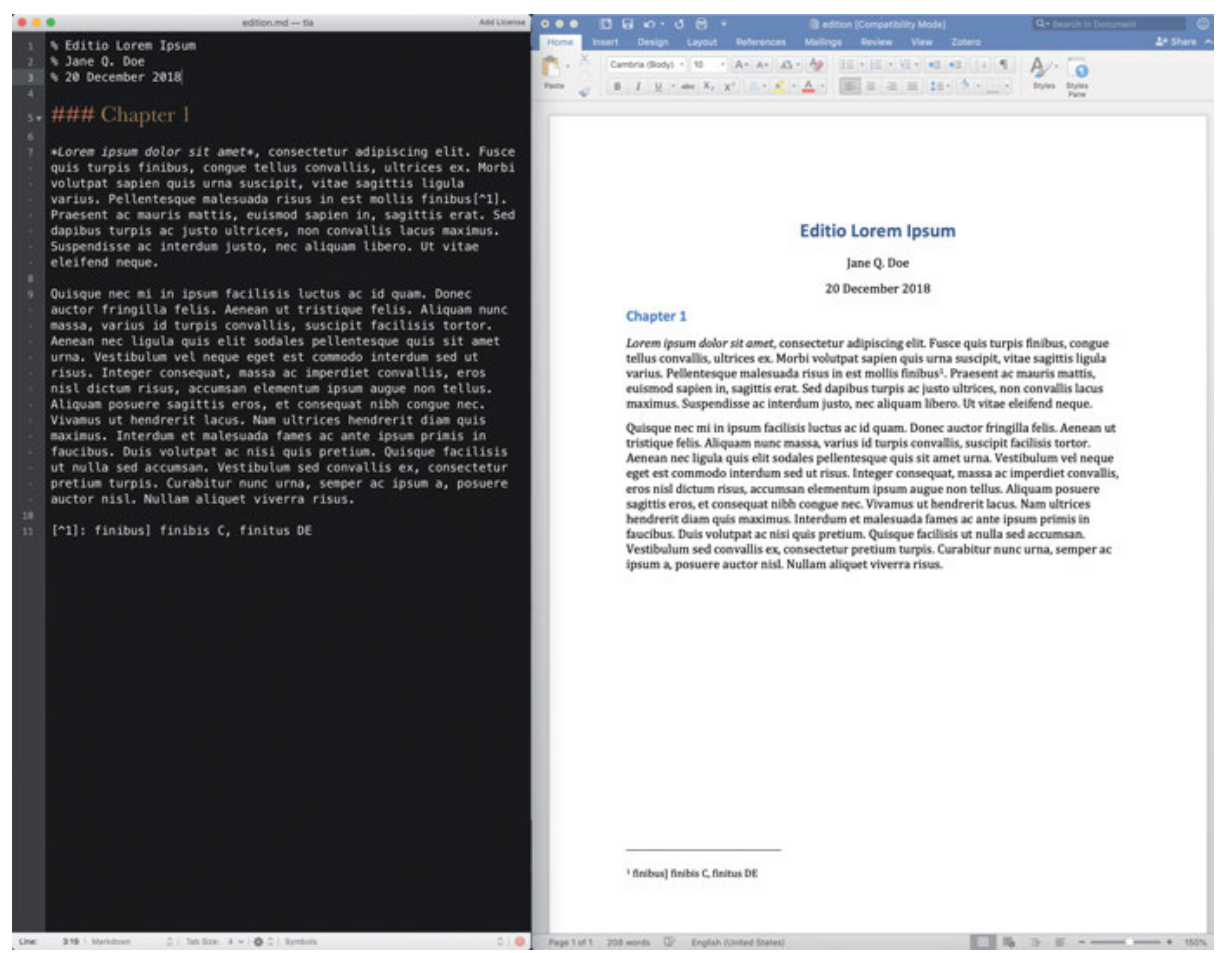

Fig. 6.4-4: Example of Markdown file and Pandoc output to MS Word.

\subsubsection{XML-based solutions}

But perhaps the editor intends that his or her edition be published not only to a print-ready format but fully electronically as a website. This will entail a set of decisions about what that website ought to look like, how the text itself is to be presented, and what sorts of interaction will be possible for its viewers. All of these decisions are heavily bound up with the editor's concept of the relevance and significance of the text and of his or her own editorial work on it (Andrews and van Zundert 2018); given the wide range of possibilities provided by the digital medium and the fact that these possibilities are not, so far, meaningfully restricted by widespread convention, it is much more common for an editor to be dissatisfied with existing software solutions for the digital publication of editions than it is for the same editor to be dissatisfied with the standard typesetting rules of well-known print-series editions.

Any editor who has online publication in mind will very likely have been encouraged to prepare the text in a TEI XML format (see 3.4.5). TEI is not, strictly speaking, a technical standard; rather, it provides an array of tools for defining one's own encoding scheme, and a set of prescriptive guidelines for the use of these tools, intended to ensure as far as possible a common vocabulary and structure. A 


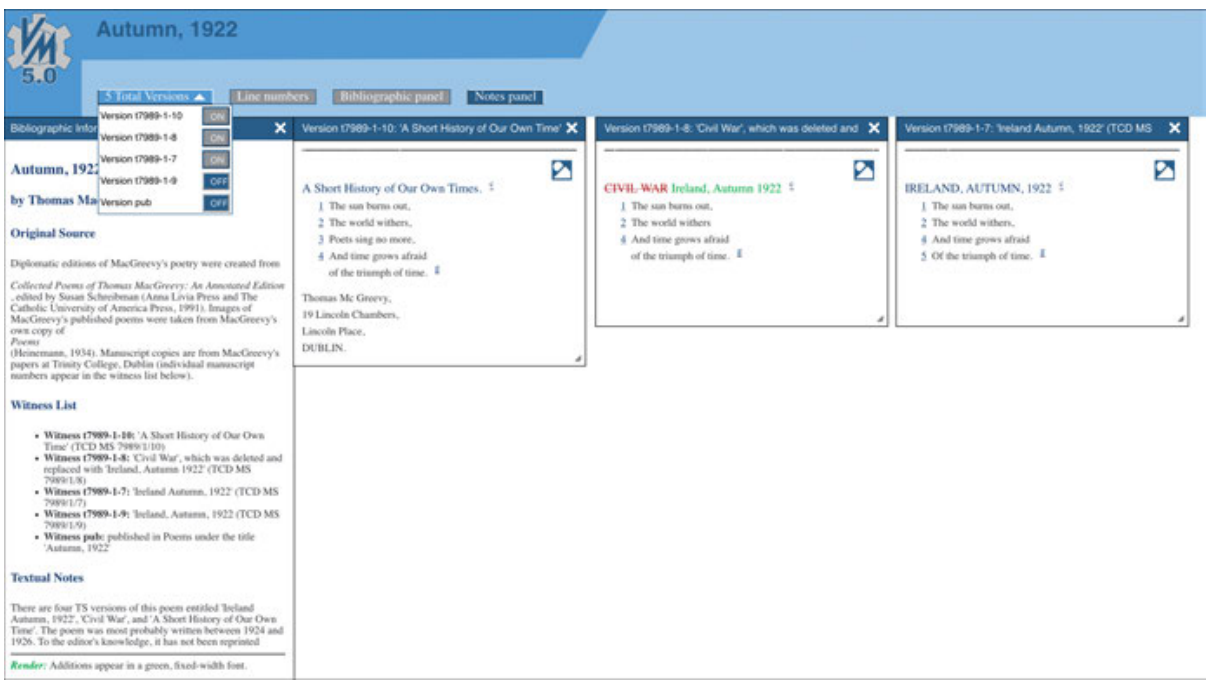

Fig. 6.4-5: Example of the Versioning Machine interface. Source: v-machine.org.

critical edition can therefore be encoded in a TEI XML format. The critical apparatus can be handled in a few different ways. TEI exported from the Classical Text Editor will use a system known as double-endpoint at tachment, which relies on the use of a base text and attaches apparatus entries directly to that text, in a similar way to the example of the LaTeX reledmac package discussed above. The other system in common use is known as parallel segmentation. This does not rely on the use of a base text, although one can be specified; as such, it can easily be used to express a text collation as well as an eventual edition. Due to the syntax limitations of XML, however, editions encoded using the parallel segmentation system cannot have overlapping apparatus entries (see 3.3.4 for situations when these might arise).

One of the primary advantages of XML is that it can be parsed by computer programs and transformed into other formats relatively easily. A common way to do this is to write a styles heet in a language known as XSLT (eXtensible Stylesheet Language Transformation), which specifies which elements of your XML document should be used for what purpose in the resulting document. These stylesheets are most commonly used to render a TEI-encoded edition into HTML for Web display, although they can also be used to transform it into LaTeX for print publication.

In theory, then, it would be possible to write a single XSLT stylesheet that could be used for any number of TEI XML-encoded editions so as to transform them into HTML. This is the idea underlying the Menota Handbook (Haugen et al. 2019), developed specifically for editions of mediaeval Norse manuscripts. The handbook provides a set of guidelines based on TEI, as well as a set of XSLT stylesheets that, when the published guidelines are followed, will render the XML-encoded edition into HTML for display in a Web page. An advantage of XSLT is that, as long as the 


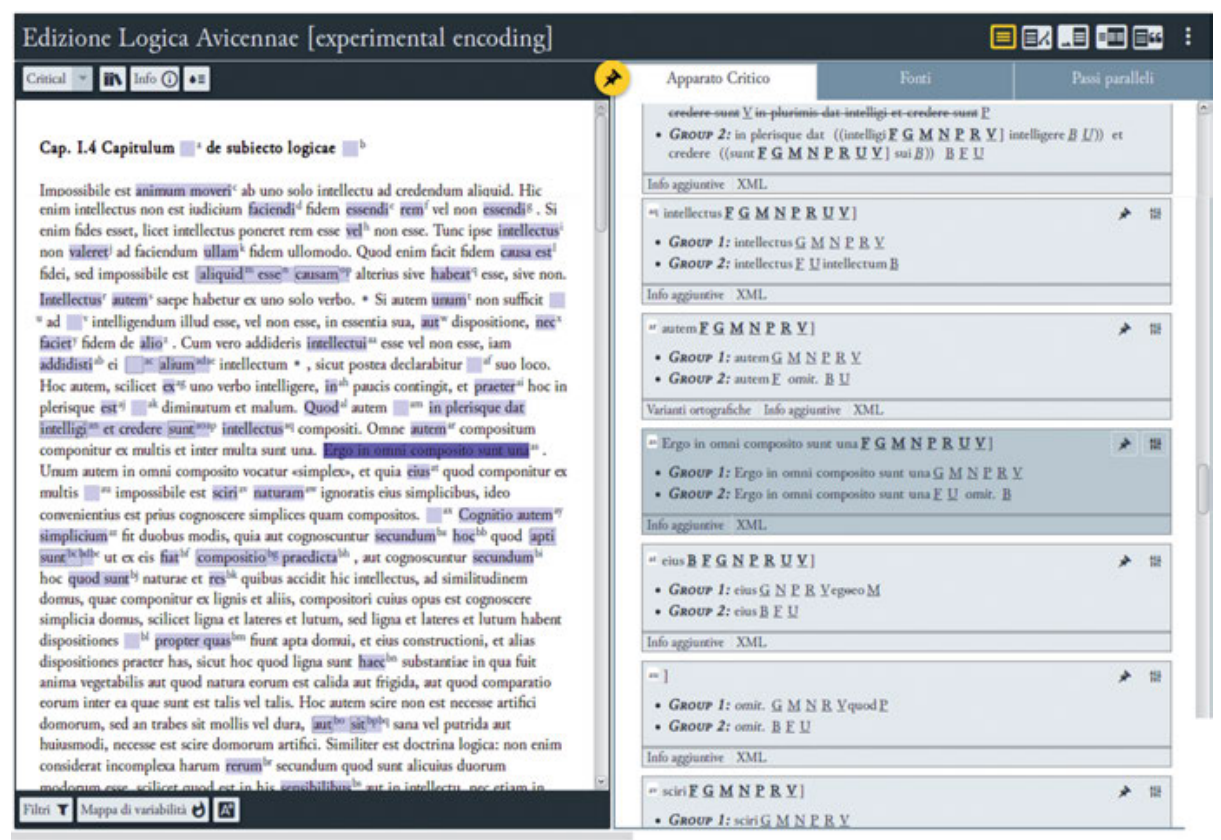

Fig. 6.4-6: Example of the EVT interface. Source: visualizationtechnology.wordpress.com.

user has a modern Web browser, there is no need to install and run additional software - the browser itself will read the XML file and the XSLT stylesheet provided that they are linked correctly, and perform the transformation automatically. Even without such a browser feature, an editor would be able to use the same software (e.g. Oxygen, a well-known XML editor) for writing the XML file and for performing the XSLT transformation. A similar piece of software, this one intended for editions of texts based on multiple witnesses, is the Versioning Machine (Schreibman, Kumar, and McDonald 2003), which uses a combination of XSLT and JavaScript to produce HTML suitable for direct publication to the Web.

Use of XML is not limited to XSLT, however; XML parsers exist for every major programming language. A software tool for the production of text editions that focuses primarily on letter collections is the ediarum program developed by the Berlin-Brandenburgische Akademie der Wissenschaften (Dumont and Fechner 2014). This program integrates multiple technologies for its use: Oxygen for creating and editing TEI XML documents; an XML database for storage of the documents; and a combination of XQuery, XSLT, and the Java programming language for Web display. Print publication is also offered through a tool based on the TeX typesetting system.

An example of a tool that avoids XSLT altogether in favour of a more generalpurpose programming language is EVT (Edition Visualization Technology; Rosselli Del Turco et al., 2014). Like the Versioning Machine, the version of EVT currently under development expects text editions to be encoded in TEI XML using the paral- 
lel segmentation system, and is intended to be a reasonably self-contained system into which editors can simply drop their files and view the result in a browser. Unlike the Versioning Machine, EVT is written in the Angular framework of the JavaScript programming language, and manipulation of the XML is handled directly in the JavaScript code.

The biggest challenge of any TEI-based out-of-the-box solution is the sheer complexity of the TEI guidelines; it is next to impossible for any software tool to support the entire range of possible encoding practices that might be adopted by edition projects. The common practice of TEI schema customisation exacerbates this even further: even if the author of a software tool devised a way to anticipate all possible usages of the elements specified in the TEI guidelines, an editor would still be free to redefine those usages, or even to add new elements, and so exceed the scope of the tool.

\subsubsection{Custom HTML solutions}

Given the paucity of ready-made specialist software packages for the publication of critical editions, and given the difficulty of developing such a package that will satisfy more than a minority of editors, perhaps the most common publication solution remains the most complex: development of a custom-coded site using the core Web technologies of HTML, CSS, and JavaScript. Although these languages require a significant investment of time to learn well, they are well within reach of scholars/ editors who have that time, as well as the interest to develop their skills.

H T M L, or HyperText Markup Language, is the standard for describing the content of Web pages. It belongs to the same family of markup syntax as XML and has, consequently, some similarities to TEI, but is simultaneously more flexible and more restricted in scope. A user of HTML can define a basic text structure including titles, paragraphs, sections, and captions; can mark out selected spans of text; can include audiovisual media; and can give all of these elements arbitrary designations using the "class" attribute. A Web page in its most basic form consists of an HTML document viewed in a browser. In the early days of the Web, all content was published solely in HTML. As the platform matured, two additional languages with their own scopes of functionality were developed in order to separate more cleanly the burgeoning dynamic functionality of websites. The first is known as CSS, or Cascading Style Sheets. These provide the means to make systematic style and aesthetic decisions for a Web document. Using a CSS stylesheet, a Web content author can control such features as fonts, colours, margins, background graphics, and much more. Completing the triumvirate of Web technologies is the programming language JavaScript. Roughly speaking, where HTML defines the content of a page and CSS defines its look and feel, J a va Scri pt defines how the reader/user can interact with a Web page. With a very few exceptions (such as navigation from page to page via hyperlinks), any action or dynamism that occurs on a Web page is controlled by a JavaScript function working on the page. 


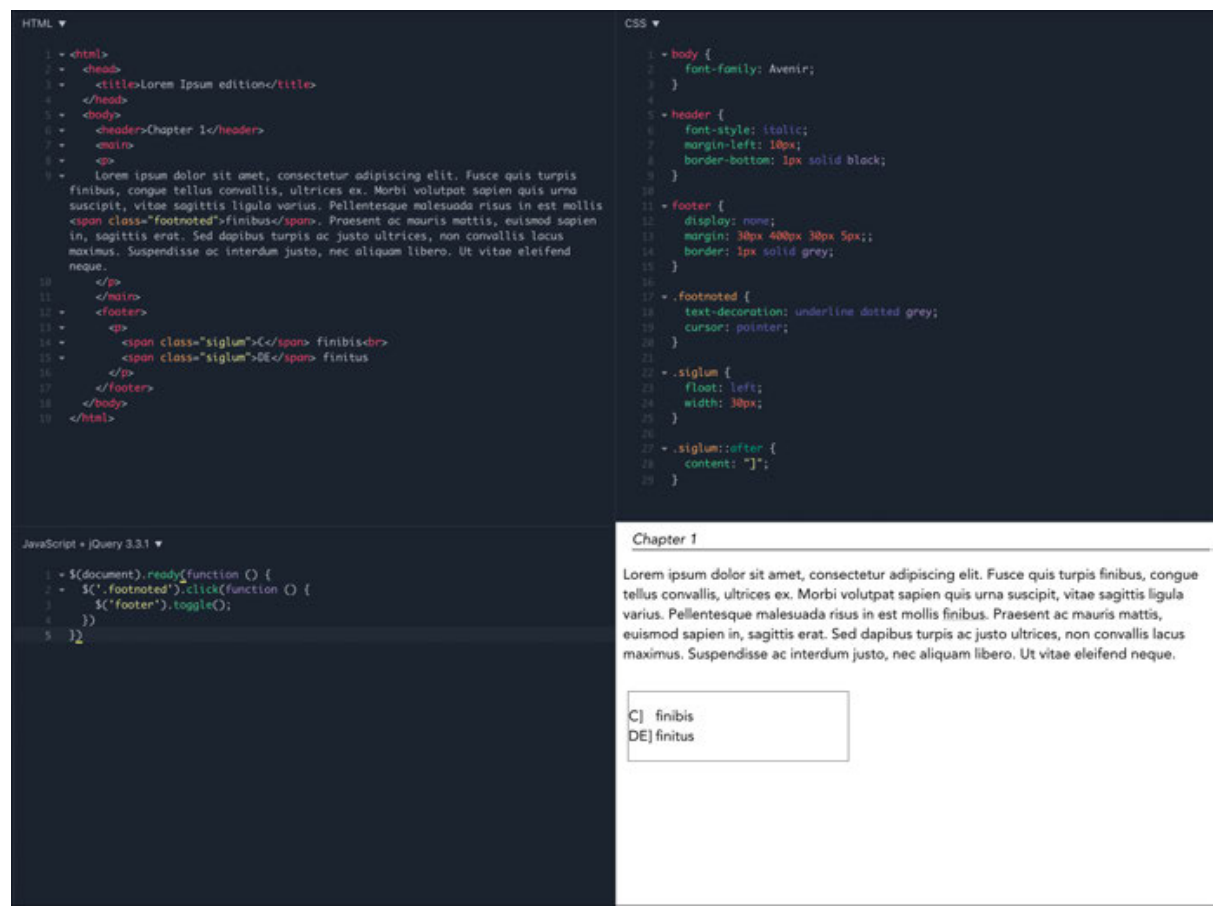

Fig. 6.4-7: An example of HTML (top left), CSS (top right), JavaScript (bottom left), and the rendered result (bottom right).

Atop these three technologies exists a vast and ever-growing ecosystem of publishing tools, frameworks, and libraries to speed up the task of Web development; by making use of these tools, or indeed by making direct and unadorned use of HTML, CSS, and JavaScript, a Web developer can publish an edition according to more or less any specification. The text may be divided arbitrarily into pages and retain a print-style critical apparatus; alternatively, it may be grouped into logical sections, with the variants displayed via JavaScript pop-ups and the sigla linked to manuscript transcriptions. Variants can be highlighted to indicate the position of their respective manuscripts in the stemma proposed by the editor, or a list of variants can be generated to allow other scholars the possibility to propose a different stemma hypothesis. Annotations to the text can be displayed as marginal notes, as hyperlinked endnotes, or hidden away entirely until the reader has a need to consult them. Editors can choose to make the manuscript transcriptions available as TEI XML downloads, or display them using normal HTML markup. The edition may include images of some or all manuscript pages, or may provide a link to the online collection of a library where a given manuscript can be viewed.

Since Web technologies themselves remain under steady and active development, the particular set of tools and frameworks employed will depend on the prior 
experience and existing skill set of the editor or Web developer, and will vary from edition to edition and from year to year. This makes standardisation around any particular tool or framework all but impossible, which remains perhaps the greatest challenge for the sustainability of digital scholarship. At the same time, custom Web development remains the only feasible option that allows editors to explore new ideas for how to present a text, and how to allow readers to engage with it.

\subsubsection{Adoption of digital solutions}

As academic institutions and funding bodies are won over to the merits of digital publication, and as the value of digitisation of source data is increasingly realised, the development of tools and software for handling the data and producing the publications is sure to continue. Nevertheless, digital publication is a difficult subject for many editors to navigate. The difficulties stem from a number of issues: first, the sheer complexity of existing standards such as TEI XML; second, the fact that Web technologies themselves are constantly maturing and changing even as archivists and textual scholars demand reliable standards; third, the relatively high level of technical skill that is necessary to develop and maintain a Web publication; fourth, the lack of incentives for those with Web development skills to apply their skills to the problem of critical edition publication; and fifth, the lack of a robust infrastructure for the maintenance of those applications that have been developed.

These are known difficulties, shared by many research domains, and are of ongoing concern to policymakers in research and higher education. In some countries, such as Switzerland and Austria, funding has been made available for initiatives to try to get to grips with the problem of sustainability for digital editions. This is particularly critical for Switzerland, for example, where, in a parallel policy move, the Swiss National Science Foundation has mandated digital publication of any edition project that it supports (Schweizerischer Nationalfonds 2014). This, along with similar de facto policies of other major research funding bodies, is an acknowledgment that digital publication, for all its challenges and pitfalls, has very quickly become an indispensable way to ensure that scholarly texts are made available, engaged with by the public, and acknowledged as relevant to our societies. 